\title{
An Overview of
}

\section{Biodiesel}

and

Petroleum Diesel

Life Cycles

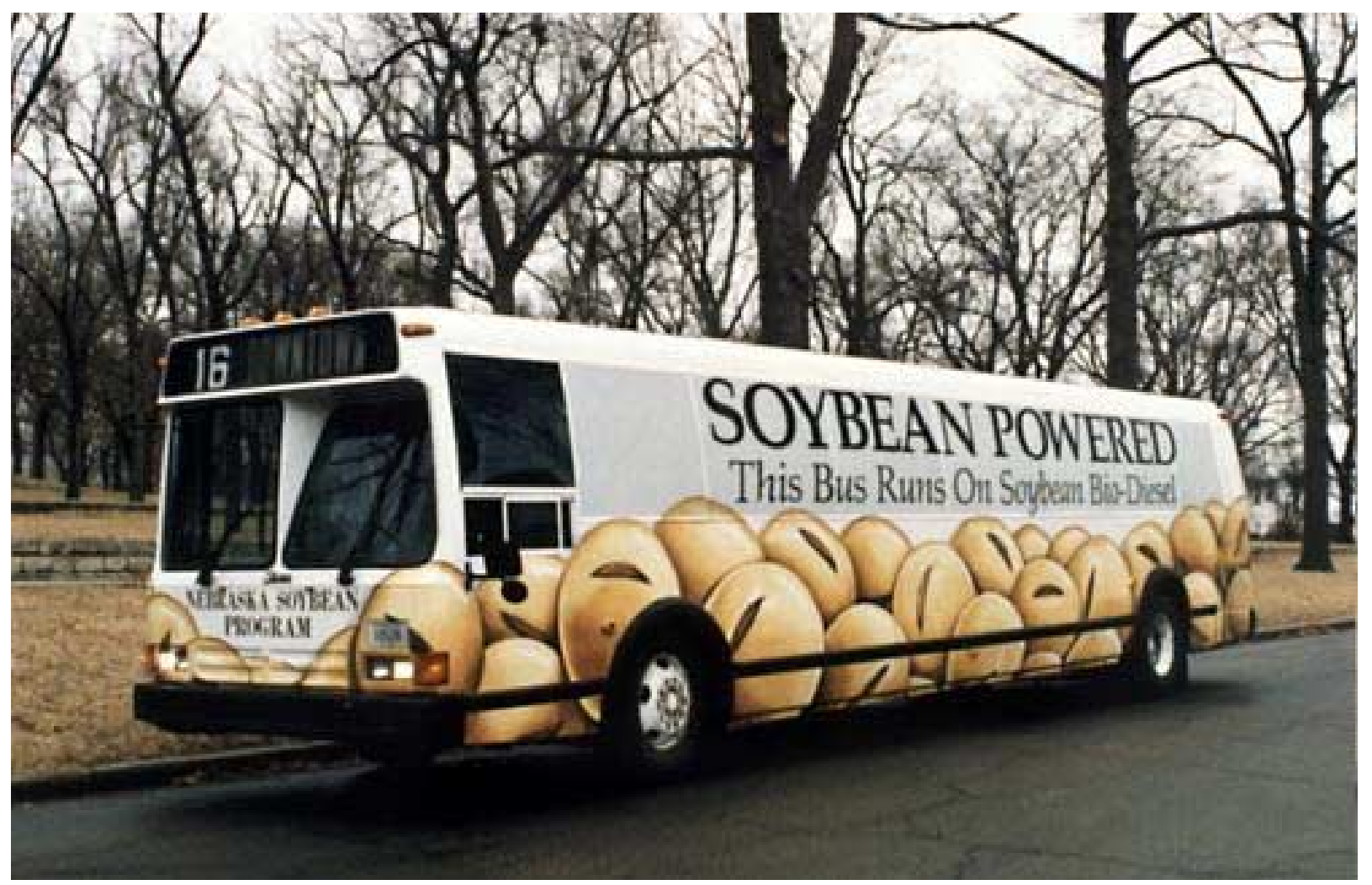

A Joint Study Sponsored by:

U.S. Department of Agriculture and

U.S. Department of Energy

May 1998 


\section{NOTICE}

This report was prepared as an account of work sponsored by an agency of the United States government. Neither the United States government nor any agency thereof, nor any of their employees, makes any warranty, express or implied, or assumes any legal liability or responsibility for the accuracy, completeness, or usefulness of any information, apparatus, product, or process disclosed, or represents that its use would not infringe privately owned rights. Reference herein to any specific commercial product, process, or service by trade name, trademark, manufacturer, or otherwise does not necessarily constitute or imply its endorsement, recommendation, or favoring by the United States government or any agency thereof. The views and opinions of authors expressed herein do not necessarily state or reflect those of the United States government or any agency thereof.

Available electronically at http://www.doe.gov/bridge

Available for a processing fee to U.S. Department of Energy and its contractors, in paper, from:

U.S. Department of Energy

Office of Scientific and Technical Information

P.O. Box 62

Oak Ridge, TN 37831-0062

phone: 865.576 .8401

fax: 865.576.5728

email: reports@adonis.osti.gov

Available for sale to the public, in paper, from:

U.S. Department of Commerce

National Technical Information Service

5285 Port Royal Road

Springfield, VA 22161

phone: 800.553 .6847

fax: 703.605.6900

email: orders@ntis.fedworld.gov

online ordering: http://www.ntis.gov/ordering.htm 


\section{An Overview of Biodiesel and Petroleum Diesel Life Cycles}

John Sheehan

Vince Camobreco

James Duffield

Michael Graboski

Housein Shapouri

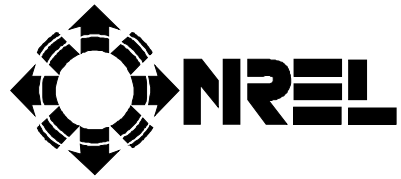

National Renewable Energy Laboratory 1617 Cole Boulevard Golden, Colorado 80401-3393 A national laboratory of the U.S. Department of Energy Operated by Midwest Research Institute Under Contract No. DE-AC02-83CH10093

Prepared under Task No. BF886002

May 1998 


\section{Acknowledgments}

Life cycle studies require thoughtfulness, hard work, and patience. We have been fortunate to have all these. The core team of workers comes from a variety of organizations, and their ability to collaborate on such a project is a tribute to their professionalism and to the dedication of these organizations.

\section{From the U.S. Department of Energy's National Renewable Energy Laboratory...}

- John Sheehan initiated and organized this effort, and provided detailed process modeling for the soybean crushing and biodiesel production technologies.

- K. Shaine Tyson, NREL project manager for DOE's Biodiesel Program, provided overview and management for the work and shared her insights based on her experience conducting a life cycle study for ethanol.

\section{From the U.S. Department of Agriculture's Office of Energy...}

a Jim Duffield coordinated this study for USDA, and was the lead contributor to the soybean agriculture portion of the model.

- Housein Shapouri, a coauthor of the soybean agriculture section, provided invaluable support in collecting and analyzing USDA's data on soybean farm practices.

\section{From Ecobalance, Inc., and the Colorado Institute for Fuels and High Altitude Engine Research (CIFER) at the Colorado School of Mines...}

Ecobalance, Inc.

a Vince Camobreco coordinated this study for Ecobalance with support from DOE, and tirelessly led the effort to construct the life cycle models for petroleum diesel and biodiesel using Ecobalance's invaluable software tools designed for this type of work. Remi Coulon and Jacques Besnainou provided technical oversight of the model development, and provided invaluable insight on life cycle modeling.

\section{CIFER}

- Mike Graboski, with the support of USDA's Office of Energy, took the lead in collecting and analyzing all the available data on biodiesel and petroleum diesel performance in bus engines.

We would be remiss if we did not recognize the hours of volunteer time put in by our stakeholders and peer reviewers. Their efforts lend credibility to this work. Finally, we want to thank the leaders at DOE and USDA for their support and patience during this long and trying effort. In particular, we would like to thank...

口 Roger Conway, USDA Office of Energy

John Ferrell and Mike Voorhies, DOE Office of Fuels Development

This overview is extracted from a detailed, comprehensive report entitled Life Cycle Inventories of Biodiesel and Petroleum Diesel for Use in an Urban Bus., NREL/SR-580-24089 UC Category 1503, National Renewable Energy Laboratory, Golden, CO. That report contains the detail engineering analysis, assumptions, and other technical material that supports this overview. For a copy of that report, contact the same addresses provided on the previous page. 


\section{Executive Summary}

\section{What is biodiesel?}

Biodiesel is a renewable diesel fuel substitute that can be made by chemically combining any natural oil or fat with an alcohol such as methanol or ethanol. Methanol has been the most commonly used alcohol in the commercial production of biodiesel. In Europe, biodiesel is widely available in both its neat form (100\% biodiesel, also known as B100) and in blends with petroleum diesel. Most European biodiesel is made from rapeseed oil (a cousin of canola oil). In the United States, initial interest in producing and using biodiesel has focused on the use of soybean oil as the primary feedstock, mainly because this country is the world's largest producer of soybean oil.

\section{Why biodiesel?}

Proponents of biodiesel as a substitute for diesel fuel (neat or in blends) point to its advantages:

\section{$\checkmark \quad$ It can reduce our dependence on foreign petroleum...}

Petroleum imports are at record levels in the United States, and will continue to rise as domestic oil supplies shrink. Our transportation sector, with its great demand for gasoline and diesel fuel, relies almost exclusively on petroleum for energy. Biodiesel can be produced domestically from agricultural oils and from waste fats and oils. Because it can be used directly in diesel engines, biodiesel offers the immediate potential to reduce our demand for petroleum.

\section{$\checkmark \quad$ It can leverage limited supplies of fossil fuels...}

Regardless of whose perspective we choose to believe on the future of coal, oil, and natural gas, their supply is, ultimately, limited. Biodiesel can help us leverage our use of these fuels.

\section{$\checkmark$ It can help reduce greenhouse gas emissions...}

The burning of fossil fuels during the past century has dramatically increased the levels of carbon dioxide $\left(\mathrm{CO}_{2}\right)$ and other "greenhouse gases" that trap heat in our atmosphere. Their implications are hotly debated, but the levels of these gases have unquestionably risen at unprecedented rates in the context of geological time ${ }^{1}$. To the extent that biodiesel is truly renewable, it could help reduce greenhouse gas emissions from the transportation sector.

\section{$\checkmark \quad$ It can help reduce air pollution and related public health risks...}

One of the U.S. Environmental Protection Agency's (EPA) primary charges is to reduce public health risks associated with environmental pollution. Biodiesel can play a role in reducing emissions of many air pollutants, especially those targeted by EPA in urban areas. These include particulate matter $(\mathrm{PM})$, carbon monoxide $(\mathrm{CO})$, hydrocarbons $(\mathrm{HC})$, sulfur oxides $\left(\mathrm{SO}_{\mathrm{x}}\right)$, nitrogen oxides $\left(\mathrm{NO}_{\mathrm{x}}\right)$, and air toxics.

\footnotetext{
${ }^{1}$ Revelle published the groundbreaking work on atmospheric $\mathrm{CO}_{2}$ buildup during the International Geophysical Year of 1957, in which he clearly stated the problem of greenhouse gases. He wrote: "Human beings are carrying out a large-scale geophysical experiment of a kind that could not have happened in the past nor be produced in the future. Within a few centuries, we are returning to the atmosphere and the oceans the concentrated organic carbon stored in sedimentary rocks over hundreds of millions of years.” Revelle, R.; Suess, H. Tellus 9(11):18-21, 1957.
} 


\section{$\checkmark \quad$ It can benefit our domestic economy...}

Spending on foreign imports of petroleum takes dollars away from our economy. Biodiesel can help us shift this spending to domestically produced energy, and offers new energy-related markets to farmers.

\section{$\checkmark$ One gallon of biodiesel provides the same benefits used neat (100\%) or used in blends, such as B20 (20\% biodiesel with 80\% diesel fuel)}

Because the tailpipe emissions of biodiesel vary linearly with the blend level, the benefit of any blend level of biodiesel can be estimated by using the following formula: percent biodiesel multiplied by biodiesel life cycle inventory plus percent diesel fuel multiplied by diesel fuel life cycle inventory.

\section{Why a life cycle analysis?}

Life cycle analyses look at the whole picture of how a fuel is made, from "cradle to grave." The life cycles begin with the extraction of all raw materials to make petroleum diesel and biodiesel, and end with using the fuels in an urban bus. Examining global issues, such as $\mathrm{CO}_{2}$ emissions, requires a comprehensive life cycle analysis. Understanding the benefits of biodiesel requires us to compare its life cycle emissions to those of petroleum diesel. This study examines biodiesel energy's balance, its effect on greenhouse gas emissions, and its effects on the generation of air, water, and solid waste pollutants for every operation needed to made biodiesel and diesel fuel. We made no attempt to quantify its domestic economic benefits.

\section{This study provides a life cycle inventory of environmental and energy flows to and from the environment for both petroleum diesel and biodiesel, as well as for blends of biodiesel with petroleum diesel.}

\section{Scope}

Life cycle analysis is a complex science. One characteristic of the process is that you have to choose very specific technologies and assumptions to represent very complex and diverse industries and systems. So life cycles can oversimplify "reality." Also, you cannot model a system or process without data. So the availability of published data often determines which technologies and assumptions are modeled in a life cycle analysis. For example, a great deal of information is available from bus engine tests and bus demonstrations of soybean-derived biodiesel, so we chose to model soybean oil production and conversion to biodiesel, and based the end use on bus applications.

\section{Findings}

Life cycle analyses all have similar limitations. Incomplete data are the rule rather than the exception. We have varying degrees of confidence in the results, but the most reliable conclusions are for overall energy balance and $\mathrm{CO}_{2}$ emissions. For these two measures, our data are the most complete. More importantly, our sensitivity studies show that the estimates of $\mathrm{CO}_{2}$ emissions and energy requirements are very robust: they show little change in response to changes in key assumptions. 


\section{Reductions in petroleum and fossil energy consumption}

Biodiesel offers tremendous potential as one component of a strategy for reducing petroleum oil dependence and minimizing fossil fuel consumption.

The benefit of using biodiesel is proportionate to
the blend level of biodiesel used. Substituting
B100 for petroleum diesel in buses reduces the life
cycle consumption of petroleum by $95 \%$. A $20 \%$
blend of biodiesel and petroleum diesel (B20)
causes the life cycle consumption of petroleum to
drop $19 \%$.

Biodiesel and petroleum diesel production processes are almost equally efficient at converting raw energy resources (in this case, petroleum or soybean oil) into fuels. Biodiesel's advantage is that its largest raw resource (soy oil) is renewable. So biodiesel requires less fossil energy (only 0.31 units) to make a 1 unit of fuel.

Biodiesel yields 3.2 units of fuel product energy for
every unit of fossil energy consumed in its life
cycle. The production of B20 yields 0.98 units of
fuel product energy for every unit of fossil energy
consumed.

By contrast, society uses 1.2 units of fossil resources to produce 1 unit of petroleum diesel. Such measures confirm the "renewable" nature of biodiesel.

\section{Reductions in $\mathrm{CO}_{2}$ emissions}

Because biodiesel production requires such small amounts of fossil fuel, its $\mathrm{CO}_{2}$ life cycle emissions are, not surprisingly, much lower than those of petroleum diesel. Displacing petroleum diesel with biodiesel in urban buses is an extremely effective strategy for reducing $\mathrm{CO}_{2}$ emissions.

\section{Biodiesel reduces net $\mathrm{CO}_{2}$ emissions by $78.45 \%$ compared to petroleum diesel. For $\mathrm{B2O}_{1} \mathrm{CO}_{2}$ emissions from urban buses drop $15.66 \%$.}

\section{Changes in air pollutant emissions}

The effect of biodiesel on air quality is complex and requires an understanding of the chemical interactions of air pollutants. To begin such an analysis, you need to know the amounts and type of air pollutants each fuel releases into the environment. Biodiesel, as it is available today, substantially reduces some air pollutants; it leads to increases in others.

Overview of Biodiesel and Petroleum Diesel Life Cycles 


\section{Using B100 in urban buses substantially reduces life cycle emissions of total particulate matter $(32 \%), \mathrm{CO}(35 \%)$, and $\mathrm{SO}_{\mathrm{x}}(8 \%)$, relative to petroleum diesel's life cycle.}

Biodiesel reduces particulate, carbon monoxide, and sulfur dioxide emissions compared to diesel fuel. The EPA targets these three emissions because they pose public health risks, especially in urban areas where they can affect more people. Because transportation emissions contribute significantly to urban concentrations of these pollutants, reducing tailpipe emissions is a powerful tool for improving air quality. Using biodiesel in buses operating in urban areas significantly reduces these pollutants.

\section{Tailpipe emissions of particulates smaller than 10 microns are $68 \%$ lower for buses that run on biodiesel (compared to petroleum diesel). Tailpipe CO emissions are $46 \%$ lower. Biodiesel completely eliminates tailpipe $\mathrm{SO}_{x}$ emissions.}

The reductions in air emissions reported here are proportional to the amount of biodiesel in the fuel. Thus, for $\mathrm{B} 20$, users can expect to see $20 \%$ of the reductions reported for B100.

$\mathrm{NO}_{\mathrm{x}}$ is one of three pollutants implicated in the formation of ground-level ozone and smog in urban areas $\left(\mathrm{NO}_{\mathrm{x}}, \mathrm{CO}\right.$, and $\left.\mathrm{HCs}\right)$. Biodiesel increases tailpipe $\mathrm{NO}_{\mathrm{x}}$ emissions, and these emission sources dominate its life cycle $\mathrm{NO}_{x}$ emission levels.

\section{The use of B100 in urban buses increases $\mathrm{NO}_{x}$ life cycle emissions by $13.35 \%$. Blending biodiesel with petroleum proportionately lowers $\mathrm{NO}_{x}$ emissions. B20 exhibits a 2.67\% increase in life $\mathrm{NO}_{x}$ Cycle emissions. Most of this increase is directly attributable to increases in NO $\mathrm{O}_{x}$ tailpipe emissions. B100, for example, increases $\mathbf{N O}_{x}$ tailpipe levels by $8.89 \%$.}

Our results are based on the performance of current fuel and engine technologies. Our study points out the need for research on improving engine design and biodiesel fuel formulation to address this problem.

The biodiesel life cycle also produces more hydrocarbon (HC) emissions compared to the diesel fuel life cycle. Most of the biodiesel life cycle emissions are produced during farming and soybean processing operations. Tailpipe HC emissions are actually lower for biodiesel than for diesel fuel. 


\section{Total life cycle emissions of HCs are 35\% higher for B100 than for petroleum diesel. However, HC emissions at the bus's tailpipe are $37 \%$ lower.}

These results point out opportunities for improving the life cycle of biodiesel. Future agricultural research should focus on ways of reducing HC releases from today's agricultural systems.

\section{Next Steps}

We designed this study to identify and quantify the advantages of biodiesel as a substitute for petroleum diesel. These advantages are substantial, especially in the areas of energy security and control of greenhouse gases. We have also identified weaknesses or areas of concern for biodiesel - such as its emissions of $\mathrm{NO}_{\mathrm{x}}$ and $\mathrm{HCs}$. We see these as opportunities for further research to resolve these concerns. We hope our findings will be used to focus research on these critical issues.

Much can be done to build on and improve the work we have done here. Next steps for this work include:

- Use the life cycle inventory to assess the relative effects of petroleum diesel and biodiesel on our environment and on public health risks to gain an understanding of the benefits associated with biodiesel.

- Quantify the costs and benefits of biodiesel.

- Assess the economic impact of biodiesel as an alternative fuel (e.g., its effects on jobs and the trade deficit).

- Evaluate other feedstock sources.

- Incorporate new health effects data on HC emissions from biodiesel and petroleum diesel.

- Develop regional life cycle models for biodiesel use.

- Evaluate performance of newer diesel engines and new fuel production technologies. 


\section{Table of Contents}

Executive Summary ..................................................................................................................ii

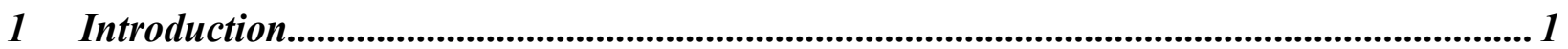

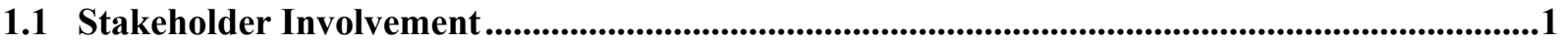

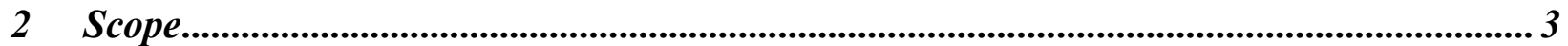

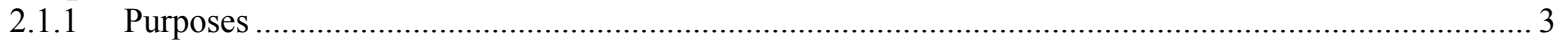

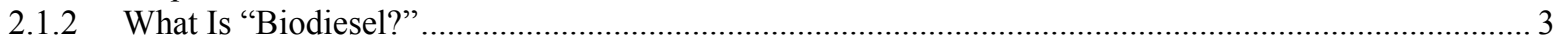

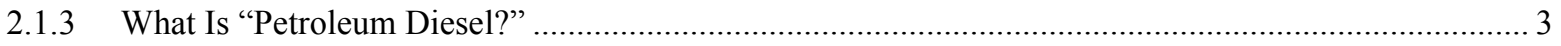

2.1.4 Defining the Product Application........................................................................................... 3

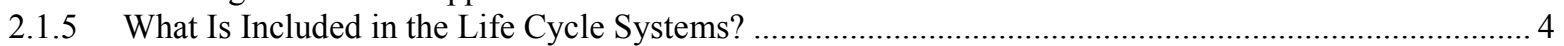

2.1.6 What Are the Geographic Boundaries? ................................................................................ 4

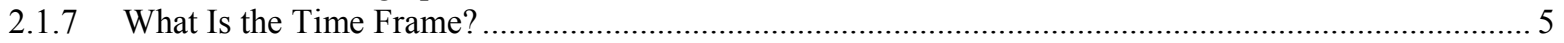

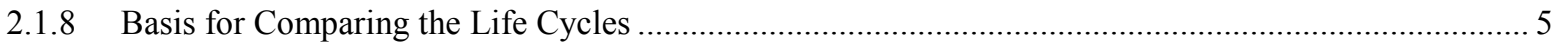

3 Key Assumptions .................................................................................................................... 6

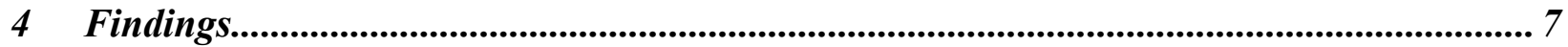

4.1 Results of the Base-Case Study ……...................................................................................................8

4.1.1 Life Cycle Energy Balance …………………………………………………………………... 8

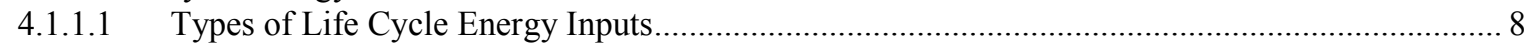

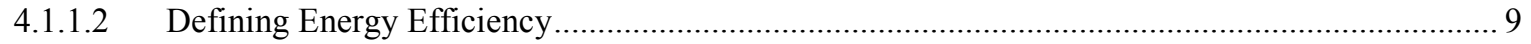

4.1.1.3 Petroleum Diesel Life Cycle Energy Consumption.................................................................. 10

4.1.1.4 Biodiesel Life Cycle Energy Demand ................................................................................. 13

4.1.1.5 Effect of Biodiesel on Life Cycle Energy Demands................................................................. 13

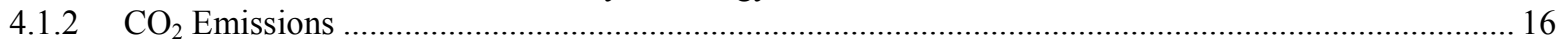

4.1.2.1 Accounting for Biomass-Derived Carbon …………………………………………………….... 16

4.1.2.2 Comparison of $\mathrm{CO}_{2}$ Emissions for Biodiesel and Petroleum Diesel ............................................ 18

4.1.3 Primary Resource Consumption for Biodiesel and Petroleum Diesel................................................. 19

4.1.4 Life Cycle Emissions of Regulated and Nonregulated Air Pollutants............................................... 20

4.1.4.1 Comparison of Life Cycle Air Emissions for Biodiesel and Petroleum Diesel ........................... 22

4.1.5 Life Cycle Emissions of Water Effluents ............................................................................. 24

4.1.6 Comparison of Solid Waste Life Cycle Flows ......................................................................... 25

4.2 Sensitivity Studies..............................................................................................................................25

4.2.1 The Effect of Enhanced Location for Biodiesel Production and Use ...............................................2 25

4.2.2 The Effect of Energy Requirements for Conversion of Soybean Oil to Biodiesel ............................... 28

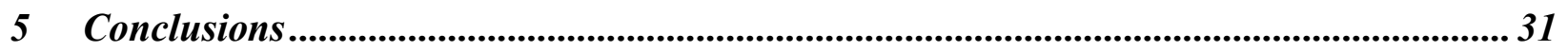

5.1 Life Cycle Energy and Environmental Flows ................................................................................31

5.2 Next Steps.........................................................................................................................................32

$6 \quad$ Life Cycle Data Tables................................................................................................................... 33 


\section{Tables}

Table 1: Geographic Scope of the Petroleum Diesel Life Cycle...................................................................5

Table 2: Geographic Scope of the Biodiesel Life Cycle .................................................................................5

Table 3: Primary Energy Requirements for the Petroleum Diesel Life Cycle ..........................................10

Table 4: Fossil Energy Requirements for the Petroleum Diesel Life Cycle ............................................12

Table 5: Primary Energy Requirements for Biodiesel Life Cycle .......................................................... 14

Table 6: Fossil Energy Requirements for the Biodiesel Life Cycle ........................................................15

Table 7: Tailpipe Contribution to Total Life Cycle $\mathrm{CO}_{2}$ for Petroleum Diesel and Biodiesel ( $\mathrm{g} \mathrm{CO}_{2} / \mathrm{bhp}$ -

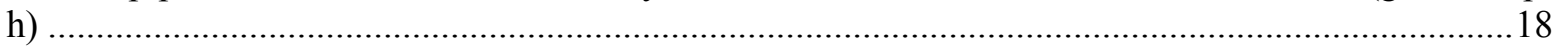

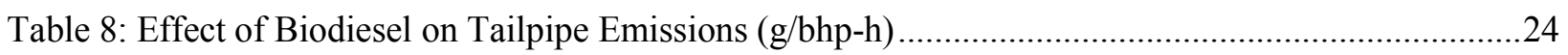

Table 9: Model Parameters for the Chicago Area Biodiesel Scenario ......................................................26

Table 10: Range of Energy Inputs for Soybean Oil Conversion Tested in LCI Model ............................28

Table 11: Primary Energy Demand for the Petroleum Diesel Life Cycle Inventory .................................34

Table 12: Fossil Energy Requirements for the Petroleum Diesel Life Cycle ...........................................34

Table 13: Primary Energy Requirements for Biodiesel Life Cycle .........................................................35

Table 14: Fossil Energy Requirements for the Biodiesel Life Cycle .......................................................35

Table 15: Biomass Carbon Balance for Biodiesel Life Cycle (g/bhp-h).................................................36

Table 16: LCI Inventory of Raw Material Consumption for Petroleum Diesel (kg/bhp-h) ......................37

Table 17: Life Cycle Consumption of Primary Resources for Biodiesel ..................................................37

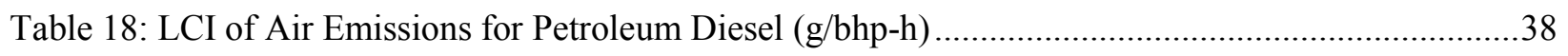

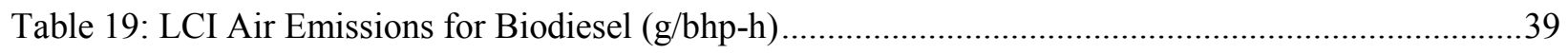

Table 20: Air Emissions for Petroleum Diesel, B20, and B100 (g/bhp-h) ............................................40

Table 21: Relative Change in Life Cycle Air Emissions for Fuels Containing 20\% and 100\% Biodiesel 41 


\section{Figures}

Figure 1: Ranking of Primary Energy Demand for the Stages of Petroleum Diesel................................11

Figure 2: Process Energy Demand for Petroleum Diesel Life Cycle .....................................................11

Figure 3: Ranking of Fossil Energy Demand for Stages of the Petroleum Diesel Life Cycle ....................12

Figure 4: Ranking of Primary Energy Demand for Stages of the Biodiesel Life Cycle ...........................14

Figure 5: Process Energy Requirements for Biodiesel Life Cycle.......................................................15

Figure 6: Fossil Energy Requirements versus Fuel Product Energy for the Biodiesel Life Cycle .............16

Figure 7: Biomass Carbon Balance for Biodiesel Life Cycle (g carbon/bhp-h) .....................................17

Figure 8: Comparison of $\mathrm{Net}_{\mathrm{CO}_{2}}$ Life Cycle Emissions for Petroleum Diesel and Biodiesel Blends ........18

Figure 9: Effect of Biodiesel Blend Level on $\mathrm{CO}_{2}$ Emissions ............................................................19

Figure 10: Petroleum Consumption for Petroleum Diesel, B20, and B100 ...........................................20

Figure 11: Coal and Natural Gas Consumption for Petroleum Diesel, B20, and B100 ...........................20

Figure 12: Water Use for Petroleum Diesel, B20, and B100 ...........................................................21

Figure 13: Life Cycle Air Emissions for B100 and B20 Compared to Petroleum Diesel Life Cycle Air

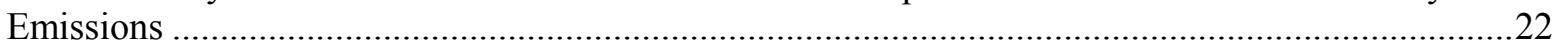

Figure 14: Comparison of Total Wastewater Flows for Petroleum Diesel and Biodiesel Life Cycles .......24

Figure 15: Hazardous Waste Generation for Petroleum Diesel, B20, and B100 ....................................25

Figure 16: Nonhazardous Waste Generation for Petroleum Diesel, B20, and B100 .............................26

Figure 17: The Effect of an Enhanced Location for Biodiesel on Life Cycle Consumption of Primary

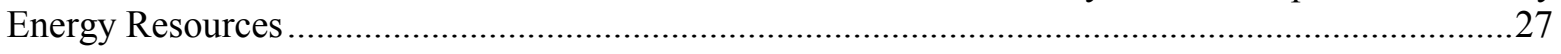

Figure 18 : Reductions in Life Cycle Air Emissions for the Chicago Area Biodiesel Scenario .................27

Figure 19: Water and Solid Waste Emissions Reductions for the Chicago Area Biodiesel Scenario.........28

Figure 20: The Effect of Conversion Energy Requirements on Primary Energy Resource Demands for

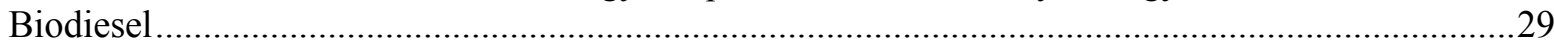

Figure 21: The Effect of Soybean Oil Conversion Energy Demands on Air Emissions for Biodiesel.......30

Figure 22: The Effect of Soybean Oil Conversion Energy Demands on Water and Solid Waste Emissions

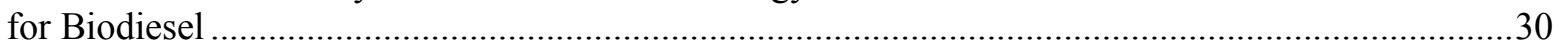

Figure 23: Effect of Biodiesel Blend on Life Cycle Air Emissions of $\mathrm{CH}_{4}, \mathrm{SO}_{\mathrm{x}}, \mathrm{HF}, \mathrm{PM} 10$, and $\mathrm{CO}$......41

Figure 24: Effect of Biodiesel Blend Level on Air Emissions of $\mathrm{NO}_{\mathrm{x}}, \mathrm{NMHC}^{2}$ and $\mathrm{HCl}$........................42

Figure 25: Primary Energy Balance for the Petroleum Diesel Fuel Life Cycle (with Mass Allocation) ....43

Figure 26: Primary Energy Balance for Petroleum Diesel Fuel Life Cycle (No Mass Allocation) ............44

Figure 27: Primary Energy Balance for Biodiesel Fuel Life Cycle (with Mass Allocation) ......................45

Figure 28: Primary Energy Balance for Biodiesel Fuel Life Cycle (No Mass Allocation)........................46 
This report presents the findings from a study of the life cycle inventories (LCIs) for petroleum diesel and biodiesel. An LCI comprehensively quantifies all the energy and environmental flows associated with a product from "cradle to grave." It provides information on:

- Raw materials extracted from the environment

- Energy resources consumed

- Air, water, and solid waste emissions generated.

By "cradle to grave," we mean all the steps from the first extraction of raw materials to the end use of the fuel. Comparing the LCIs of two or more fuels provides insights to their relative strengths and weaknesses. LCIs are also used to examine greenhouse gas emissions because these emissions can be produced anywhere in a fuel's life cycle. LCIs include other environmental emissions as well, particularly regulated air emissions such as carbon monoxide $(\mathrm{CO})$, hydrocarbons $(\mathrm{HCs})$, nitrogen oxides $\left(\mathrm{NO}_{\mathrm{x}}\right)$, sulfur oxides $\left(\mathrm{SO}_{\mathrm{x}}\right)$, and particulate matter $(\mathrm{PM})$. These LCI data will be used by industry and government decision makers considering biodiesel as an alternative fuel. This study is the product of a highly effective partnership between the U.S. Department of Agriculture (USDA) and the U.S. Department of Energy (DOE). This partnership has brought together the agricultural and energy expertise needed to adequately address an LCI of biodiesel.

\subsection{Stakeholder Involvement}

A good life cycle study uses every opportunity to obtain input from everyone who has a stake in the final outcome. This is especially true for life cycle studies being conducted to support important government policy decisions. Many early decisions made in setting the scope of the study (see section 2) can have a profound effect on its outcome. All stakeholders must therefore have an opportunity to:

- Discuss the key assumptions and options.

- Provide input throughout the project to ensure that the best available data are used and interpreted properly.

- Provide their perspective on the results as they become available to help the researchers avoid "tunnel vision."

The most important reason for stakeholder involvement is credibility. When studies are done in a vacuum, they stand little chance of getting acceptance from the industries involved. In the end, LCI results are only as good as the "buy-in" or level of credibility they engender.

We made stakeholder involvement a top priority. The following groups provided input:

- Petroleum Industry

- Oilseed Processing Industry

- Animal Renderers and Recyclers

- Chemical Process Industry 
- Biodiesel Producers

- Engine Manufacturers

- U.S. Department of Agriculture

- U.S. Department of Energy

- U.S. Environmental Protection Agency

- State and Local Governments

- Environmental Public Interest Groups.

Stakeholders were given many opportunities to communicate with us in writing, by phone, and by e-mail, as well as in our face-to-face meetings.

1. Before pen was put to paper, USDA and DOE brought together a consortium of stakeholders at a meeting hosted by USDA in Washington, DC, to discuss the needs and goals of our study.

2. Based on input from this group, a preliminary scoping document was put together and distributed for review.

3. A second face-to-face meeting with stakeholders was held to work out the details of the project scope.

4. Once the basic data were collected on all aspects of the petroleum diesel and biodiesel life cycles, the stakeholders reconvened to review the data. Feedback from this meeting resulted in our updating data sources and filling in gaps.

5. Finally, once results from the LCI model were available, we sought detailed comments from a representative group of stakeholders (those willing to put in the time to study our results). They were given a first draft of this report. Their comments have been carefully compiled. Wherever possible, we made changes to the model and the report to reflect their concerns and criticisms. This document is a product of that final review.

The quality of our results is much better for the input of these groups. We are indebted to those who participated. 


\subsubsection{Purposes}

The purposes of this study were to (1) conduct an LCI to quantify and compare the comprehensive sets of environmental flows (to and from the environment) associated with biodiesel and petroleum-based diesel, over their life cycles; and (2) provide the information to answer the questions posed by policy makers:

\subsubsection{What Is "Biodiesel?"}

In its most general sense, "biodiesel" refers to any diesel fuel substitute derived from renewable biomass. More specifically, biodiesel refers to a family of products made from vegetable oils or animal fats and alcohol, such as methanol or ethanol, called alkyl esters of fatty acids. For these to be considered as viable transportation fuels, they must meet stringent quality standards. One popular process for producing biodiesel, modeled in this report, is "transesterification."

Biodiesel is made from a variety of natural oils, especially rapeseed oil (a close cousin of canola oil) and soybean oil. Rapeseed oil dominates the growing biodiesel industry in Europe. In the United States, biodiesel is made from soybean oil because more soybean oil is produced here than all other sources of fats and oil combined. There are many other feedstock candidates, including recycled cooking oils, animal fats, and other oilseed crops. We selected soybean oil because of the vast number of data about this oil as a biodiesel feedstock.

We chose methanol for our model because it is the most widely used alcohol for biodiesel production, it is easy to process, and is relatively low cost. Thus, our working definition of biodiesel is a diesel fuel substitute made by transesterifying soybean oil with methanol. In industry parlance, it is called soy methyl ester or methyl soyate.

\subsubsection{What Is "Petroleum Diesel?"}

We defined petroleum diesel as "on-highway" low-sulfur diesel made from crude oil. Recent regulations promulgated by the U.S. Environmental Protection Agency (EPA), as part of its enforcement of the 1990 Clean Air Act Amendments, set tougher restrictions for on-road versus off-road diesel. The "on-highway" diesel must now meet limits for sulfur content that are an order of magnitude lower than previously allowed ( $0.05 \mathrm{wt} \%$ versus $0.5 \%$ sulfur). We restrict our evaluation of petroleum diesel to this diesel ${ }^{2}$.

\subsubsection{Defining the Product Application}

The fuels' end uses can greatly affect the life cycle flows. Potential markets for biodiesel cover a wide range of applications, including most truck operations, stationary generation, mining equipment, marine diesel engines, and bus fleets. We compare petroleum diesel and biodiesel in urban buses because many

\footnotetext{
${ }^{2}$ In our analysis, low-sulfur diesel fuel is used in urban buses. This is not true for agricultural use of diesel fuel in soybean production. Data for "off-highway" diesel-powered tractors characterize performance and emissions of these engines. This diesel is not held to the same strict standard for sulfur content.
} 
end-use data are available. The U.S. biodiesel industry early on identified the urban bus market as a nearterm opportunity, and many data are available on the performance of diesel bus engines.

\subsubsection{What Is Included in the Life Cycle Systems?}

Major operations within the boundary of the petroleum diesel system include:

- Extract crude oil from the ground

- Transport crude oil to an oil refinery

- Refine crude oil to diesel fuel

- Transport diesel fuel to its point of use

- Use the fuel in a diesel bus engine.

For the biodiesel system, major operations include:

- Produce soybeans

- Transport soybeans to a soy crushing facility

- Recover soybean oil at the crusher

- Transport soybean oil to a biodiesel manufacturing facility

- Convert soybean oil to biodiesel

- Transport biodiesel fuel to the point of use

- Use the fuel in a diesel bus engine.

This is not a comprehensive list of what we modeled. These operations include detailed processes described in detail in the comprehensive report, Life Cycle Inventories of Biodiesel and Petroleum Diesel for Use in an Urban Bus. For example, crude oil extraction includes flows from operations such as onshore and offshore drilling and natural gas separation. Onshore drilling is further characterized as either conventional or advanced technology.

In addition to the energy and environmental flows in each step, we include energy and environmental inputs from raw materials production. Generally, life cycle flows are characterized for all raw materials from the point of extraction. For example, methanol use in the biodiesel manufacturing facility contributes life cycle flows that go back to the extraction of natural gas. Likewise, we include life cycle flows from intermediate energy sources such as electricity - back to the extraction of coal, oil, natural gas, limestone, and other primary resources.

\subsubsection{What Are the Geographic Boundaries?}

The LCA is limited to the use of petroleum diesel and biodiesel in the United States; however, it includes some steps that go beyond domestic boundaries. Petroleum diesel's life cycle, in particular, includes foreign crude oil production because half the crude oil used in the United States is imported. Other aspects of the geographic limits involve the choice of national versus regional or even site-specific assessment. For domestic operations, we rely on national average data. For foreign operations, we rely on industry average data. Electricity generation is modeled on a national basis. Table 1 and Table 2 present specific information on the geographic scope of the analysis for each stage of the petroleum diesel and biodiesel life cycles. 
Table 1: Geographic Scope of the Petroleum Diesel Life Cycle

\begin{tabular}{|l|l|}
\hline \multicolumn{1}{|c|}{ Life Cycle Stage } & \multicolumn{1}{c|}{ Geographic Scope } \\
\hline Crude Oil Extraction & $\begin{array}{l}\text { International average based on the consumption of crude oil in the } \\
\text { United States }\end{array}$ \\
\hline Crude Oil Transportation & International average transportation distances to the United States \\
\hline Crude Oil Refining & U.S. national average \\
\hline Diesel Fuel Transportation & U.S. national average \\
\hline Diesel Fuel Use & U.S. national average based on urban bus use \\
\hline
\end{tabular}

Table 2: Geographic Scope of the Biodiesel Life Cycle

\begin{tabular}{|l|l|}
\hline \multicolumn{1}{|c|}{ Life Cycle Stage } & \multicolumn{1}{c|}{ Geographic Scope } \\
\hline Soybean Agriculture & Average based on data from the 14 key soybean-producing states \\
\hline Soybean Transportation & U.S. national average \\
\hline Soybean Crushing & $\begin{array}{l}\text { U.S. national average based on modeling of a generic U.S. crushing } \\
\text { facility }\end{array}$ \\
\hline Soybean Oil Transport & U.S. national average \\
\hline Soybean Oil Conversion & U.S. average based on modeling of a generic biodiesel facility \\
\hline Biodiesel Transportation & U.S. national average \\
\hline Biodiesel Fuel Use & U.S. national average based on urban bus use \\
\hline
\end{tabular}

\subsubsection{What Is the Time Frame?}

We were faced with two basic options: (1) model technology and markets as they are today; or (2) model a futuristic scenario based on projected technology and markets. We chose to focus on the present, so we consider production and end-use technologies now available for petroleum diesel and biodiesel. In doing so, we ignore future advances in production efficiency, emission reduction, new technology, and other changes that reasonable people anticipate. The benefit of basing the analysis on current technology and markets it that the analysis is far more "grounded" and objective because it relies on documented data rather than on projections. The results provide a baseline for considering future scenarios.

\subsubsection{Basis for Comparing the Life Cycles}

Common sense dictates that two fuels should be compared on the same basis. So the "service" that the fuels provide, in our case the work that the bus engine provide, is the unit of comparison. For example, for light-duty vehicles, like automobiles, the service provided by the fuel is that it propels the vehicle for 1 mile. For heavy-duty diesel engines, the common unit of "work" is a brake-horsepower hour (bhp-h). Once this shared function is defined, a comparison of fuel life cycles for diesel engines characterizes all life cycle flows per bhp-h of diesel bus service. 


\section{Key Assumptions}

Details of the assumptions and modeling steps of the life cycle are presented in the comprehensive report, Life Cycle Inventories of Biodiesel and Petroleum Diesel Used in an Urban Bus. However, there are two assumptions worth noting here for a better appreciation of the LCIs shown in this report. One, national average distances were used to describe the transportation distances for all feedstocks, intermediate products, and fuels. We also tested the effect of this assumption in a sensitivity analysis to see what impact this assumption has on the LCI results. Two, both fuels were assumed to be used in engines calibrated to meet 1994 EPA regulations for diesel exhaust when operated on low-sulfur petroleum diesel. Other assumptions that will help the reader understand the fuel cycles we modeled include:

- Sources of crude oil, domestic and foreign, are split almost evenly.

- Publicly available refinery data were used to model a "generic" refinery.

- Engine emissions from petroleum diesel are taken from published 1994 engine certification data.

Biodiesel assumptions include:

- Agriculture practices and yields are based on weighted averages for 14 soybean-producing states.

- Emissions are based on actual engine data for biodiesel emissions that are then modeled as changes in the oxygen content ${ }^{3}$ in the fuel.

- Energy efficiencies of biodiesel-fueled engines are identical to those of petroleum diesel-fueled engines ${ }^{4}$.

- Biomass-derived carbon dioxide $\left(\mathrm{CO}_{2}\right)$ in the fuel emissions is recycled in soybean production.

- Soybean crushing and soy oil esterification data were based on published data and engineering models.

\footnotetext{
${ }^{3}$ Diesel fuel contains no oxygen. The amount of oxygen is a measure of biodiesel content in the fuel. Also, percent oxygen proves to be a good basis for predicting emissions.

${ }^{4}$ This is substantiated with an analysis of engine performance data.
} 


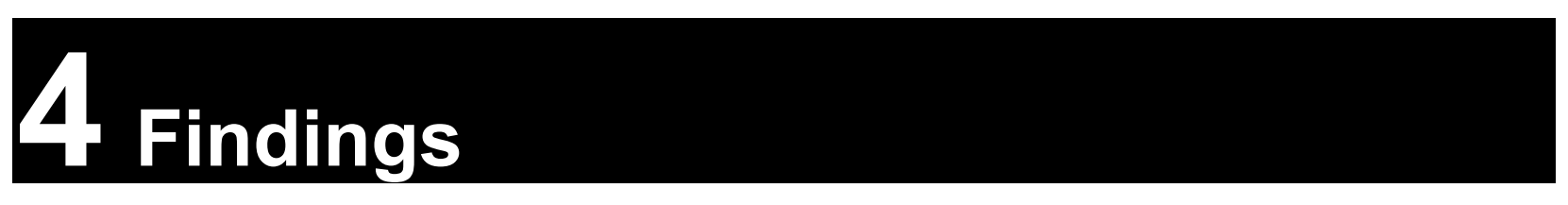

LCI results are presented for 100\% biodiesel (B100), a 20\% blend of biodiesel with petroleum diesel (B20), and petroleum diesel. These results include estimates of:

- Overall energy requirements

- $\mathrm{CO}_{2}$ emissions

- Other regulated and non-regulated air emissions. Regulated pollutants include carbon monoxide (CO), particulate matter smaller than 10 microns (PM10), non-methane hydrocarbons (NMHC), and nitrogen oxides $\left(\mathrm{NO}_{\mathrm{x}}\right)$. Non-regulated air emissions include methane $\left(\mathrm{CH}_{4}\right)$, formaldehyde, benzene, total hydrocarbons (THC), and total particulate matter (TPM).

- Water emissions

- Solid wastes.

These life cycle flows are presented for the base-case scenarios and for two sensitivity studies. The base case describes petroleum diesel and biodiesel life cycle flows for "national average" scenarios.

We conducted sensitivity studies on the biodiesel life cycle to establish sensitivities associated with key assumptions.

1. We felt it was important to understand the impact of location on biodiesel production. This allows us to consider the benefits of the best agricultural productivity available in the United States and the shortest distances for transporting fuel and materials. It also sets an upper bound on biodiesel benefits from the perspective of current agricultural practices and transportation logistics.

2. We identified the conversion of soybean oil to biodiesel as an aspect of the life cycle that has significant impact on energy use and emissions and that has a broad range of efficiencies, depending on the commercial technology used.

Our base-case estimate of the energy requirements for soy oil conversion is based on a preliminary engineering design that was loosely based on data from a transesterification plant in Kansas City, Missouri. Our energy budget proved to be much lower than that reported for this facility. A literature review of recent technology revealed that our design estimate is at the high end of the range of recently published literature values. To deal with this disparity, we decided to look at the range of reported energy budgets as a sensitivity study.

Changes in engine and processing technologies may also create avenues for improving biodiesel on a life cycle basis. We opted to forego this area in our sensitivity analysis because of limited data. Thus, we present the results of two sensitivity studies:

- We compared the base case for B100 with the LCI for an optimal biodiesel location (Chicago), based on an evaluation of regions with the most efficient soybean production, local concentration of soybean producers, and large end-use markets for urban buses.

- We compared results for a range of high and low energy demands for soybean conversion to biodiesel to determine the impact of this biodiesel life cycle stage on overall emissions and energy flows. We 
based low and high values for energy consumption on a literature survey of the most recent, commercially available, technologies.

\subsection{Results of the Base-Case Study}

The LCI results allow a side-by-side comparison of biodiesel and petroleum diesel fuels. Both LCIs reflect generic "national average" models. The only exception is soybean agriculture data, which are provided for each of the 14 key soybean-producing states. These were used because they provided a level of detail that was not available at a national level.

In most cases, biodiesel is interchangeable with petroleum diesel without engine modifications. However, one key issue for biodiesel is the effect of regional climate on its performance. Its cold flow properties may limit its use in certain parts of the country during the winter. Researchers are evaluating ways to mitigate biodiesel's cold flow properties, but no clear solution is at hand. Low-sulfur \#2 diesel fuel has similar limitations that are being addressed with the use of additives and by blending with \#1 diesel fuel.

The LCI results that are covered in the following sections include (1) life cycle energy balances, (2) $\mathrm{CO}_{2}$ cycles for each life cycle, (3) major air pollutants for each life cycle, and (4) the results of both sensitivity analyses.

\subsubsection{Life Cycle Energy Balance}

LCIs provide an opportunity to quantify the total energy demands and the overall energy efficiencies of processes and products. We need to understand the overall energy requirements of biodiesel to be able to understand the extent to which biodiesel made from soybean oil is renewable. The more fossil energy required to make a fuel, the less this fuel is renewable. Thus, the renewable nature of a fuel can vary across the spectrum of "completely renewable" (no fossil energy input) to nonrenewable (fossil energy inputs as much or more than the energy output of the fuel $)^{5}$. Energy efficiency estimates help us determine how much additional energy must be expended to convert the energy available in raw materials used in the fuel's life cycle to a useful transportation fuel. The following sections describe these basic concepts in more detail, as well as the results of our analysis of the life cycle energy balances for biodiesel and petroleum diesel.

\subsubsection{Types of Life Cycle Energy Inputs}

We tracked several types of energy flows through each fuel life cycle. Each energy flow is defined below.

- Total Primary Energy. All raw materials extracted from the environment can contain ${ }^{6}$ energy. In estimating the total primary energy inputs to each fuel's life cycle, we consider the cumulative energy content of all resources extracted from the environment.

\footnotetext{
${ }^{5}$ This statement is an oversimplification. We consider the energy trapped in soybean oil to be renewable because it is solar energy stored in liquid form through biological processes that are much more rapid than the geologic time frame associated with fossil energy formation. Also, other forms of nonrenewable energy besides fossil fuel exist.

6 The energy "contained" in a raw material is the amount of energy that would be released by the complete combustion of that raw material. This "heat of combustion" can be measured as either a higher or a lower heating value. Combustion causes $\mathrm{CO}_{2}$ and water to form. Higher heating values consider the amount of energy released when the final combustion products are gaseous $\mathrm{CO}_{2}$ and liquid water. Lower heating values take into account the loss of energy associated with the vaporization of the liquid water combustion product. Our energy content is based on the lower heating values for each material.
} 
- Feedstock Energy. Energy contained in raw materials that end up directly in the final fuel product is termed "feedstock energy." For biodiesel production, feedstock energy includes the energy contained in the soybean oil and methanol feedstocks that are converted to biodiesel. Likewise, the petroleum directly converted to diesel in a refinery contains primary energy that is considered a feedstock energy input for petroleum diesel. Feedstock energy is a subset of the primary energy inputs.

- Process Energy. The second major subset of primary energy is "process energy." This is limited to energy inputs in the life cycle exclusive of the energy contained in the feedstock (as defined in the previous bullet). It is the energy contained in raw materials extracted from the environment that does not contribute to the energy of the fuel product itself, but is needed in the processing of feedstock energy into its final fuel product form. Process energy consists primarily of coal, natural gas, uranium, and hydroelectric power sources consumed directly or indirectly in the fuel's life cycle.

- Fossil Energy. Because we are concerned about the renewable nature of biodiesel, we also track the primary energy that comes from fossil sources specifically (coal, oil, and natural gas). All three of the previously defined energy flows can be categorized as fossil or nonfossil energy.

- Fuel Product Energy. The energy contained in the final fuel product, which is available to do work in an engine, is what we refer to as the "fuel product energy." All other things being equal, fuel product energy is a function of the energy density of each fuel.

\subsubsection{Defining Energy Efficiency}

We report two types of energy efficiency. The first is the overall "life cycle energy efficiency." The second is the "fossil energy ratio." Each illuminates a different aspect of the life cycle energy balance for the fuels studied.

The calculation of the life cycle energy efficiency is the ratio of fuel product energy to total primary energy:

$$
\text { Life Cycle Energy Efficiency = Fuel Product Energy/Total Primary Energy }
$$

This ratio estimates the total amount of energy that goes into a fuel cycle compared to the energy contained in the fuel product. This efficiency accounts for losses of feedstock energy and additional process energy needed to make the fuel.

The fossil energy ratio tells us something about the degree to which a fuel is or is not renewable. It is defined as the ratio of the final fuel product energy to the amount of fossil energy required to make the fuel:

\section{Fossil Energy Ratio = Fuel Energy/Fossil Energy Inputs}

If the fossil energy ratio has a value of zero, a fuel is completely nonrenewable and provides no usable fuel product energy because of the fossil energy consumed to make the fuel. If the fossil energy ratio is 1 , it is still nonrenewable because no energy is lost in the process of converting the fossil energy to a usable fuel. For fossil energy ratios greater than 1 , the fuel begins to leverage the fossil energy required to make it available for transportation. As a fuel approaches "complete" renewability, its fossil energy ratio approaches "infinity." That is, a completely renewable fuel has no fossil energy requirements.

From a policy perspective, these are important considerations. Policy makers want to understand how much a fuel increases the renewability of our energy supply. Another implication of the fossil energy ratio is the question of climate change. Higher fossil energy ratios imply lower net $\mathrm{CO}_{2}$ emissions. This is a secondary aspect of the ratio, as we are explicitly estimating total $\mathrm{CO}_{2}$ emissions from each fuel's life cycle. Nevertheless, the fossil energy ratio checks on our calculation of $\mathrm{CO}_{2}$ life cycle flows (the two should be correlated). 


\subsubsection{Petroleum Diesel Life Cycle Energy Consumption}

Table 3 and Figure 1 show the total primary energy requirements for the key steps in producing and using petroleum diesel. The LCI model shows that $1.2007 \mathrm{MJ}$ of primary energy is used to make $1 \mathrm{MJ}$ of petroleum diesel fuel. This corresponds to a life cycle energy efficiency of $83.28 \%{ }^{7}$.

The distribution of the primary energy requirements for each stage of the petroleum diesel life cycle is shown in Table 3. In Figure 1, the stages of petroleum diesel production are ranked from highest to lowest in terms of primary energy demand. Ninety-three percent of the primary energy demand is for extracting crude oil from the ground. About $88 \%$ of the energy shown for crude oil extraction is associated with the energy value of the crude oil. The crude oil refinery step for making diesel fuel dominates the remaining $7 \%$ of the primary energy use.

Removing the feedstock energy of the crude from the primary energy total allows us to analyze the relative contributions of the process energy used in each life cycle. Process energy used in each stage of the petroleum life cycle is shown in Figure 2. Process energy demand represents $20 \%$ of the energy ultimately available in the petroleum diesel fuel product. About $90 \%$ of the total process energy is in refining $(60 \%)$ and extraction $(29 \%)$. The next largest contribution to total process energy is for transporting foreign crude oil to domestic petroleum refiners.

Table 3: Primary Energy Requirements for the Petroleum Diesel Life Cycle

\begin{tabular}{|l|c|c|}
\hline \multicolumn{1}{|c|}{ Stage } & Primary Energy (MJ per MJ of Fuel) & Percent \\
\hline Domestic Crude Production & 0.5731 & $47.73 \%$ \\
\hline Foreign Crude Oil Production & 0.5400 & $44.97 \%$ \\
\hline Domestic Crude Transport & 0.0033 & $0.28 \%$ \\
\hline Foreign Crude Transport & 0.0131 & $1.09 \%$ \\
\hline Crude Oil Refining & 0.0650 & $5.41 \%$ \\
\hline Diesel Fuel Transport & 0.0063 & $0.52 \%$ \\
\hline Total & 1.2007 & $100.00 \%$ \\
\hline
\end{tabular}

There are some significant implications in the process energy results shown in Figure 2 regarding trends for foreign and domestic crude oil production and use. Transportation of foreign crude oil by tanker carries a fourfold penalty for energy consumption compared to domestic petroleum transport because it increases the travel distance for foreign oil by roughly a factor of four.

At the same time, domestic crude oil extraction is more energy intensive than foreign crude oil production. Advanced oil recovery practices in the United States represent $11 \%$ of the total production volume, compared to $3 \%$ for foreign oil extraction. Advanced oil recovery uses twice as much primary energy per kilogram of oil than conventional extraction. Advanced crude oil extraction requires almost 20 times more process energy than onshore domestic crude oil extraction because the processes are energy intensive and the amount of oil recovered is lower than with other practices. Domestic crude oil supply is essentially equal to foreign oil supply (50.26\% versus $49.74 \%)$ in our model, but its process energy requirement is $62 \%$ higher than that of foreign crude oil production (see Figure 2).

${ }^{7}$ Using the total primary energy reported in Table 3, Life Cycle Energy Efficiency $=1 \mathrm{MJ}$ of Fuel Product Energy/1.2007 MJ of Primary Energy Input $=0.8328$. 


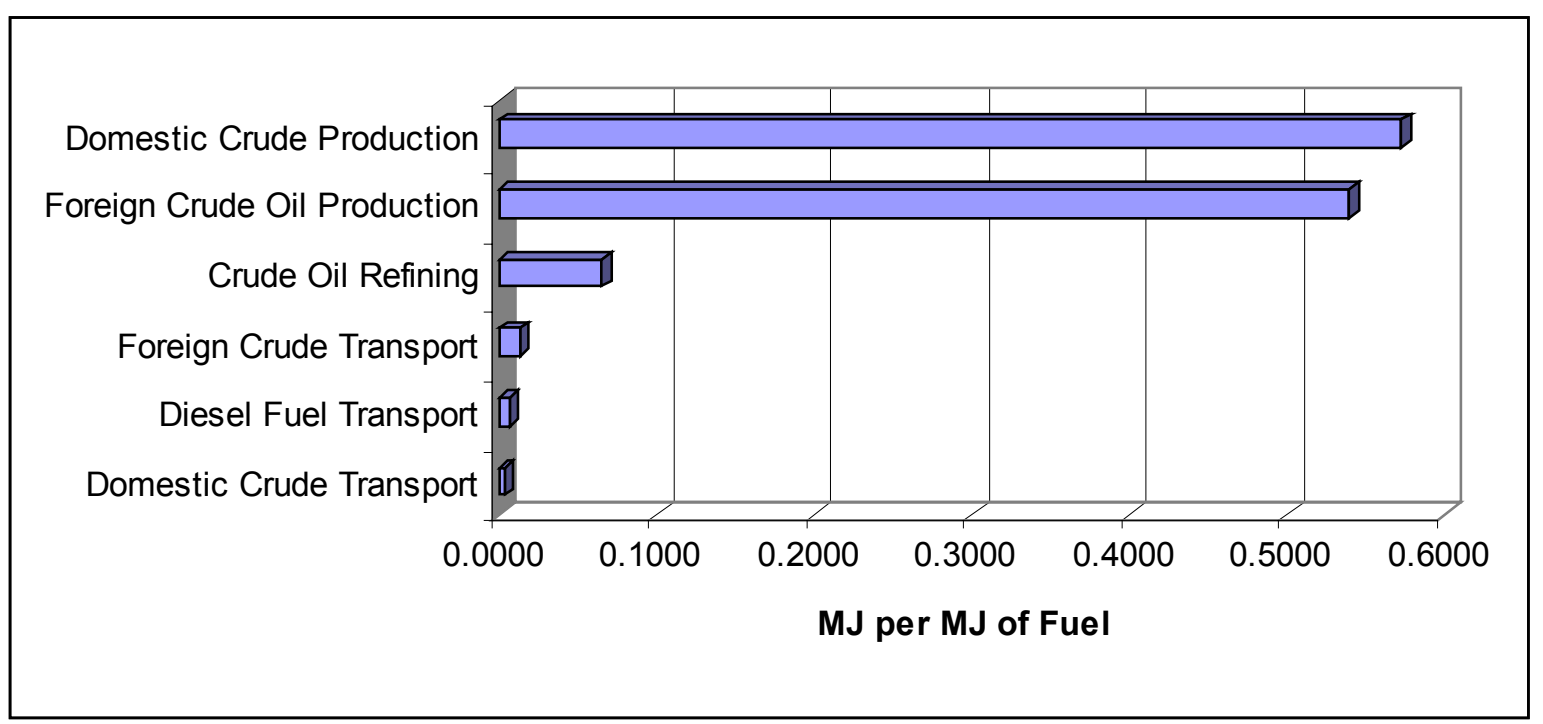

Figure 1: Ranking of Primary Energy Demand for the Stages of Petroleum Diesel

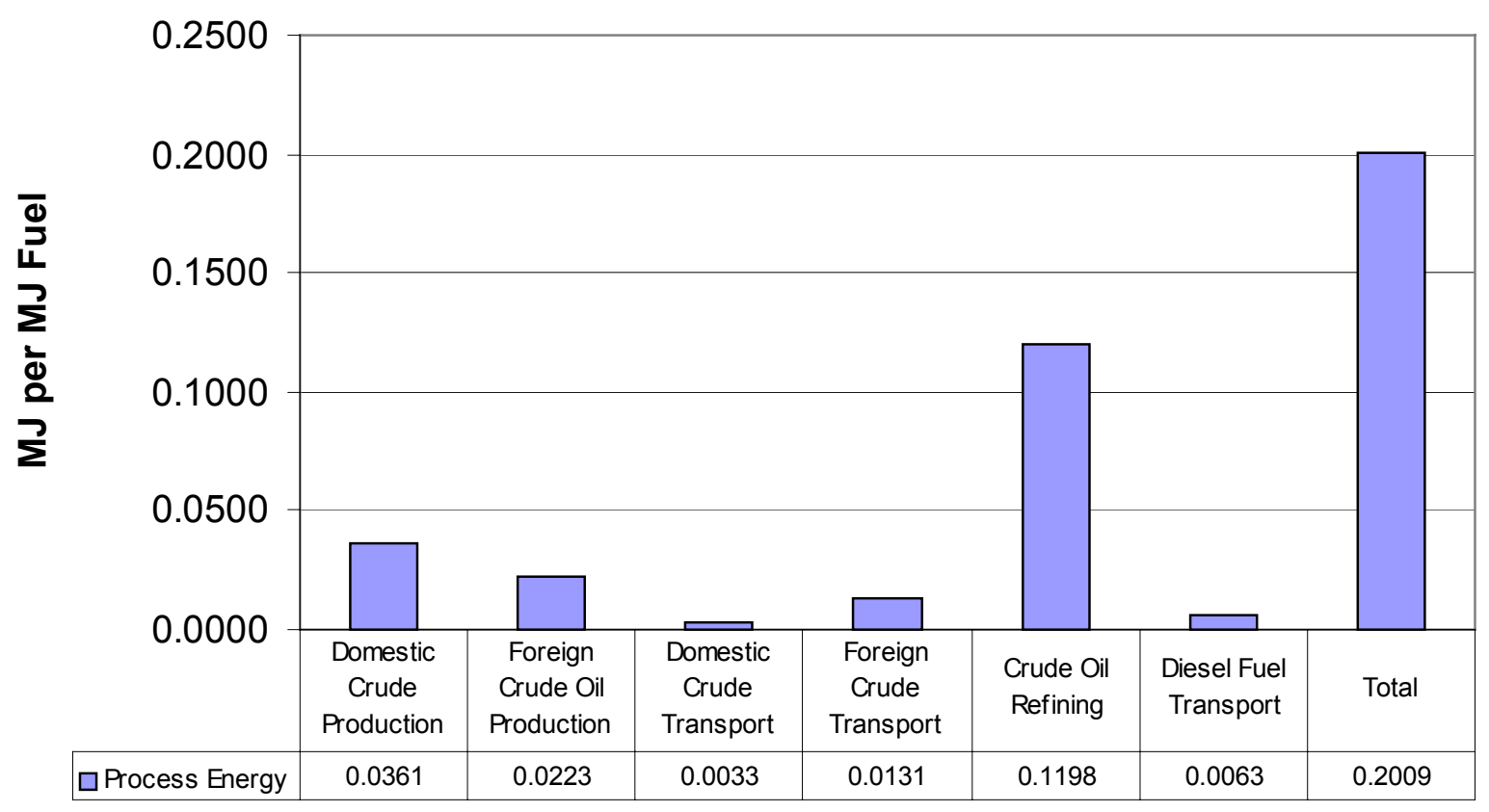

Figure 2: Process Energy Demand for Petroleum Diesel Life Cycle

If our present trend of increased dependence on foreign oil continues, we can expect the life cycle energy efficiency of petroleum diesel to worsen because of the higher energy costs of transporting foreign crude to the United States. Also, with declining domestic oil supplies, we may see increased energy penalties for domestic crude oil extraction, as advanced oil recovery becomes more common. 
Table 4 and Figure 3 summarize the fossil energy inputs with respect to petroleum diesel's energy output. Petroleum diesel uses 1.1995 MJ of fossil energy to produce $1 \mathrm{MJ}$ of fuel product energy. This corresponds to a fossil energy ratio of $0.8337^{8}$. Because the main feedstock for diesel production is a fossil fuel, this ratio is, not surprisingly, almost identical to the life cycle energy efficiency of $83.28 \%$. In fact, fossil energy associated with the crude oil feedstock accounts for $93 \%$ of the total fossil energy consumed in the life cycle. The fossil energy ratio is slightly less than the life cycle energy ratio because there is a very small contribution to the total primary energy demand, which is met through hydroelectric and nuclear power supplies related to electricity generation.

Table 4: Fossil Energy Requirements for the Petroleum Diesel Life Cycle

\begin{tabular}{|l|c|c|}
\hline \multicolumn{1}{|c|}{ Stage } & Fossil Energy (MJ per MJ of Fuel) & Percent \\
\hline Domestic Crude Production & 0.572809 & $47.75 \%$ \\
\hline Foreign Crude Oil Production & 0.539784 & $45.00 \%$ \\
\hline Domestic Crude Transport & 0.003235 & $0.27 \%$ \\
\hline Foreign Crude Transport & 0.013021 & $1.09 \%$ \\
\hline Crude Oil Refining & 0.064499 & $5.38 \%$ \\
\hline Diesel Fuel Transport & 0.006174 & $0.51 \%$ \\
\hline Total & 1.199522 & $100.00 \%$ \\
\hline
\end{tabular}

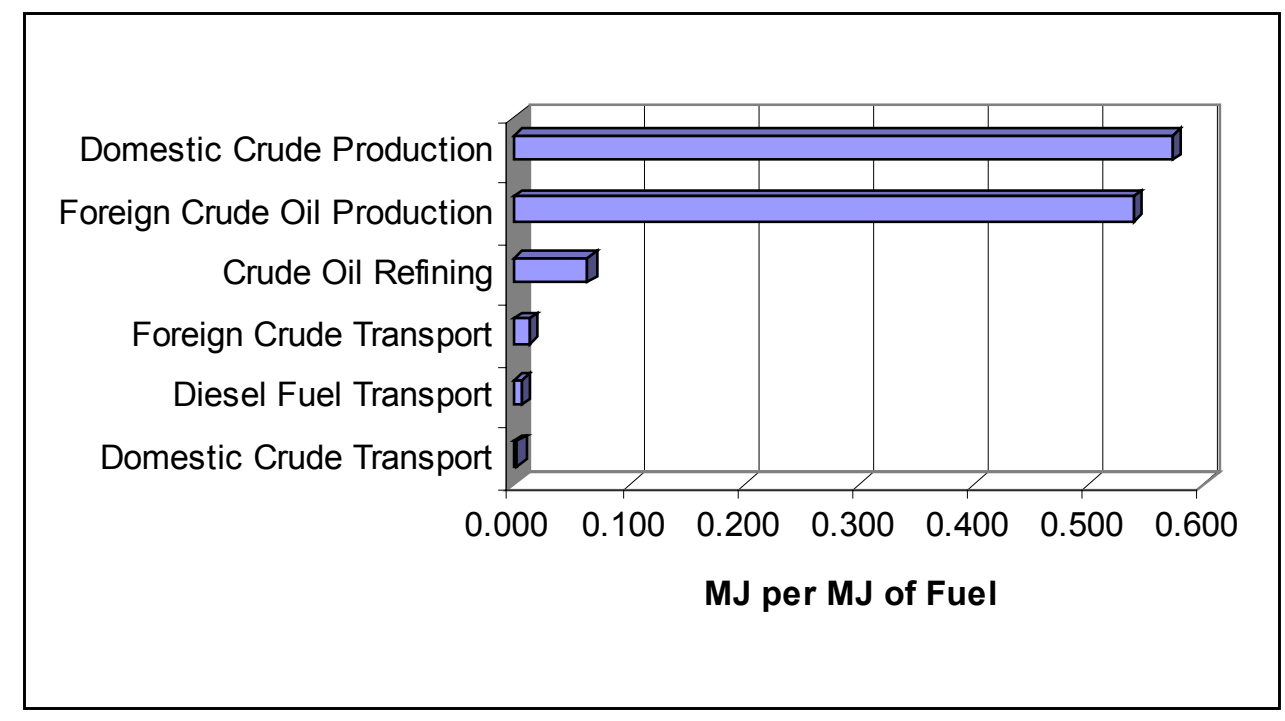

Figure 3: Ranking of Fossil Energy Demand for Stages of the Petroleum Diesel Life Cycle

${ }^{8}$ Fossil Energy Ratio = 1 MJ Fuel Energy/1.1995 MJ of Fossil Energy Input $=0.8337$. 


\subsubsection{Biodiesel Life Cycle Energy Demand}

Table 5 and Figure 4 present the total primary energy demand used in each stage of the biodiesel life cycle. One MJ of biodiesel requires an input of $1.2414 \mathrm{MJ}$ of primary energy, resulting in a life cycle energy efficiency of $80.55 \%$. Biodiesel is comparable to petroleum diesel in the conversion of primary energy to fuel product energy ( $80.55 \%$ versus $83.28 \%$ ). The largest contribution to primary energy ( $87 \%)$ is the soybean oil conversion step because this is where the feedstock energy associated with the soybean oil is included ${ }^{9}$. As with the petroleum life cycle, the stages of the life cycle that are burdened with the feedstock energy overwhelm all other stages. Had the soybean oil energy been included with the farming operation, soybean agriculture would have been the dominant consumer of primary energy. This is analogous to placing the crude oil feedstock energy in the extraction stage for petroleum diesel fuel. The next two largest primary energy demands are for soybean crushing and soybean oil conversion. They account for most of the remaining $13 \%$ of the total demand. When we look at process energy separately from primary energy, we see that energy demands in the biodiesel life cycle are not dominated by soybean oil conversion (Figure 5). The soybean crushing demands $34.25 \%$ of the total process energy; soy oil conversion demands $34.55 \%$. Agriculture accounts for almost $25 \%$ of the total demand. Each transportation step is only $2 \%-3 \%$ of the process energy used in the life cycle.

Table 6 and Figure 6 summarize the fossil energy requirements for the biodiesel life cycle. Because 90\% of its feedstock requirements (soybean oil) are renewable, biodiesel's fossil energy ratio is favorable. Biodiesel uses $0.3110 \mathrm{MJ}$ of fossil energy to produce $1 \mathrm{MJ}$ of fuel product; this equates to a fossil energy ratio of 3.215. In other words, the biodiesel life cycle produces more than three times as much energy in its final fuel product as it uses in fossil energy. Fossil energy demand for the conversion step is almost twice that of its process energy demand, making this stage of the life cycle the largest contributor to fossil energy demand. The use of methanol as a feedstock in the production of biodiesel accounts for this high fossil energy demand. We have counted the feedstock energy of methanol coming into the life cycle at this point, assuming that the methanol is produced from natural gas. This points out an opportunity for further improvement of the fossil energy ratio by substituting natural gas-derived methanol with renewable sources of methanol, ethanol, or other alcohols.

\subsubsection{Effect of Biodiesel on Life Cycle Energy Demands}

Compared on the basis of primary energy inputs, biodiesel and petroleum diesel are essentially equivalent. Biodiesel has a life cycle energy efficiency of $80.55 \%$, compared to $83.28 \%$ for petroleum diesel. The slightly lower efficiency reflects a slightly higher demand for process energy across the life of cycle for biodiesel. On the basis of fossil energy inputs, biodiesel enhances the effective use of this finite energy resource because it leverages fossil energy inputs by more than three to one.

\footnotetext{
${ }^{9}$ Energy contained in the soybean oil represents, in effect, the one place in the biodiesel life cycle where input of solar energy is accounted for. Total radiant energy available to soybean crops is essentially viewed as "free" in the life cycle calculations. It becomes an accountable element of the life cycle only after it has been incorporated in the soybean oil. This is analogous to counting the feedstock energy of crude petroleum as the point in its life cycle where solar energy input occurs. Petroleum is essentially stored solar energy. The difference between petroleum and soybean oil as sinks for solar energy is their time scale. Soybean oil traps solar energy on a rapid ("real time") basis; petroleum storage occurs in geologic time. This difference in the dynamic nature of solar energy use is the key to our definitions of renewable and nonrenewable energy.
} 
Table 5: Primary Energy Requirements for Biodiesel Life Cycle

\begin{tabular}{|l|c|c|}
\hline \multicolumn{1}{|c|}{ Stage } & $\begin{array}{c}\text { Primary Energy } \\
\text { (MJ per MJ of Fuel })\end{array}$ & Percent \\
\hline Soybean Agriculture & 0.0660 & $5.32 \%$ \\
\hline Soybean Transport & 0.0034 & $0.27 \%$ \\
\hline Soybean Crushing & 0.0803 & $6.47 \%$ \\
\hline Soy Oil Transport & 0.0072 & $0.58 \%$ \\
\hline Soy Oil Conversion & 1.0801 & $87.01 \%$ \\
\hline Biodiesel Transport & 0.0044 & $0.35 \%$ \\
\hline Total & 1.2414 & $100.00 \%$ \\
\hline
\end{tabular}

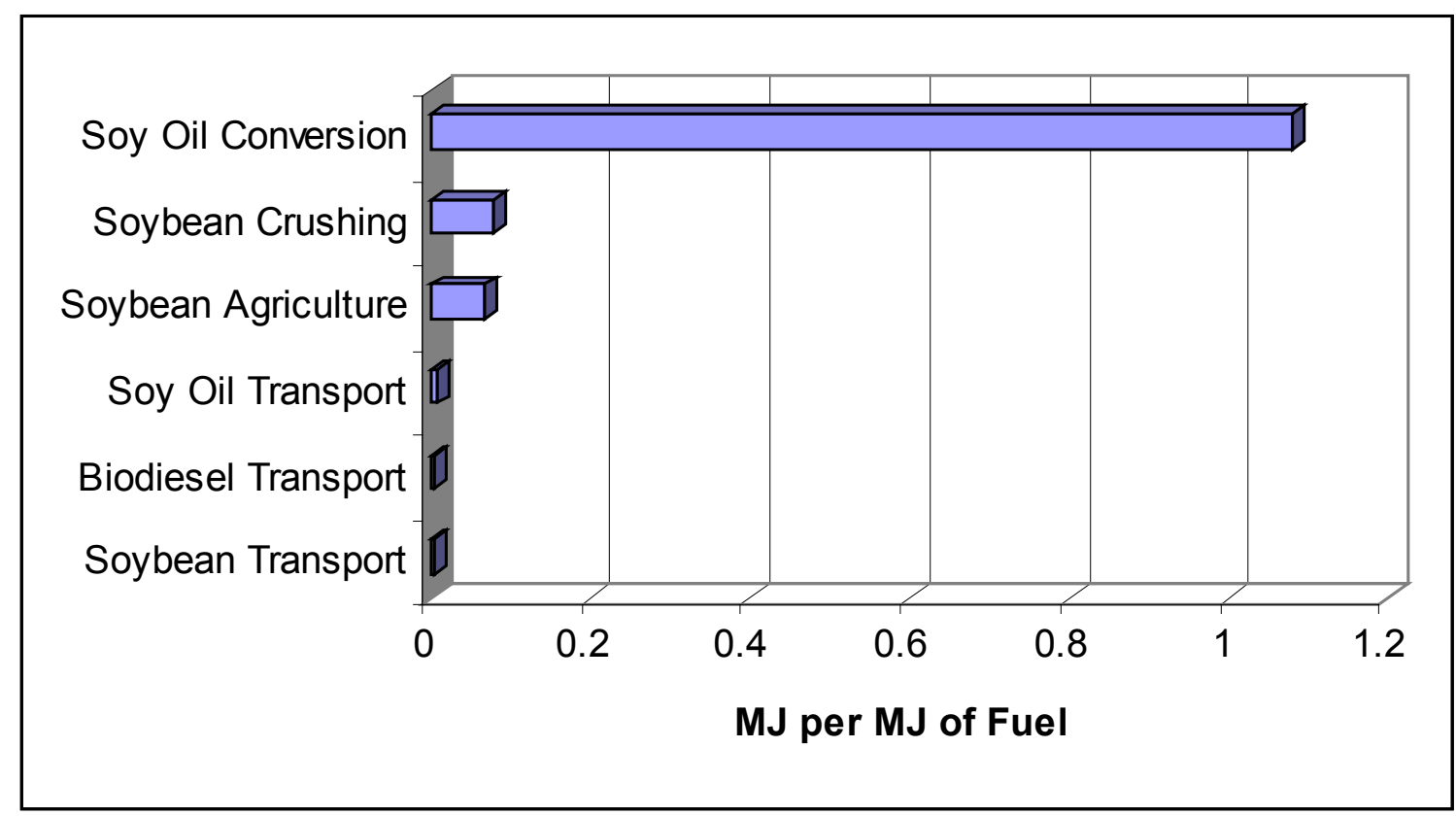

Figure 4: Ranking of Primary Energy Demand for Stages of the Biodiesel Life Cycle 


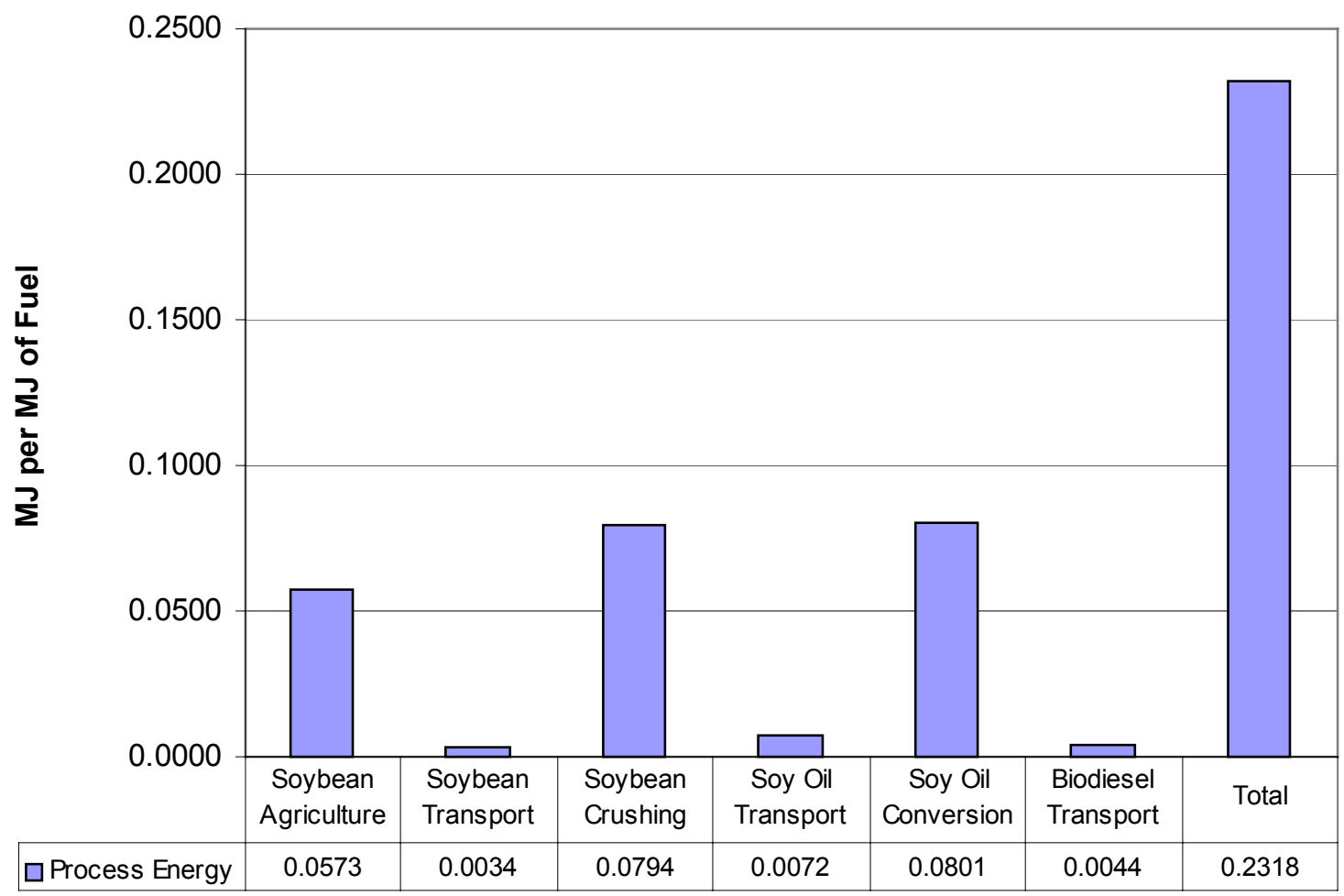

Figure 5: Process Energy Requirements for Biodiesel Life Cycle

Table 6: Fossil Energy Requirements for the Biodiesel Life Cycle

\begin{tabular}{|l|c|c|}
\hline \multicolumn{1}{|c|}{ Stage } & Fossil Energy (MJ per MJ of Fuel) & Percent \\
\hline Soybean Agriculture & 0.0656 & $21.08 \%$ \\
\hline Soybean Transport & 0.0034 & $1.09 \%$ \\
\hline Soybean Crushing & 0.0796 & $25.61 \%$ \\
\hline Soy Oil Transport & 0.0072 & $2.31 \%$ \\
\hline Soy Oil Conversion & 0.1508 & $48.49 \%$ \\
\hline Biodiesel Transport & 0.0044 & $1.41 \%$ \\
\hline Total & 0.3110 & $100.00 \%$ \\
\hline
\end{tabular}




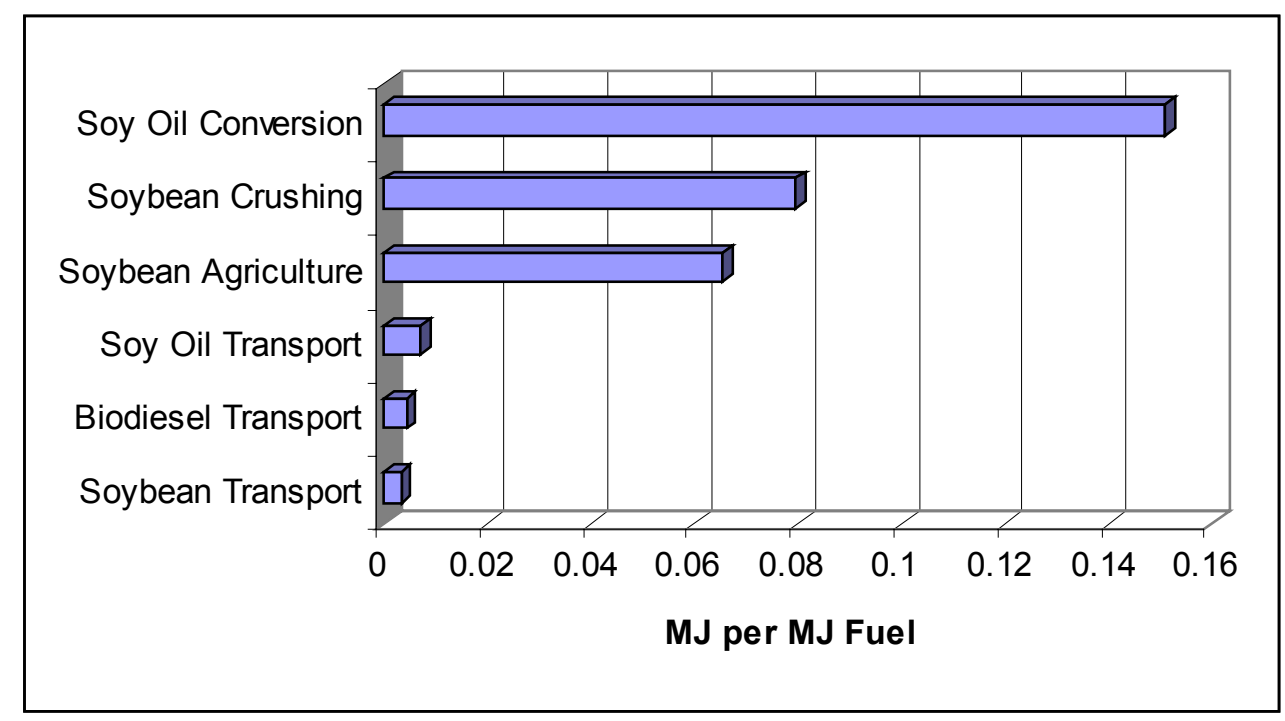

Figure 6: Fossil Energy Requirements versus Fuel Product Energy for the Biodiesel Life Cycle

\subsection{2 $\mathrm{CO}_{2}$ Emissions}

\subsubsection{Accounting for Biomass-Derived Carbon}

Biomass plays a unique role in the dynamics of carbon flow in our biosphere. Carbon is biologically cycled when plants such as soybean crops convert atmospheric $\mathrm{CO}_{2}$ to carbon-based compounds through photosynthesis. This carbon is eventually returned to the atmosphere as organisms consume the biological carbon compounds and respire. Biomass-derived fuels reduce the net atmospheric carbon in two ways. First, they participate in the relatively rapid biological cycling of carbon to the atmosphere (via engine tailpipe emissions) and from the atmosphere (via photosynthesis). Second, they displace fossil fuels. Fossil fuel combustion releases carbon that took millions of years to be removed from the atmosphere; combustion of biomass fuels participates in a process that allows $\mathrm{CO}_{2}$ to be rapidly recycled to fuel. The net effect of shifting from fossil fuels to biomass-derived fuels is thus to reduce the amount of $\mathrm{CO}_{2}$ in the atmosphere.

Because of the differences in the dynamics of fossil carbon flow and biomass carbon flow to and from the atmosphere, biomass carbon must be accounted for separately from fossil-derived carbon. The LCI model tracks carbon from the point at which it is taken up as biomass via photosynthesis to its final combustion as biodiesel used in an urban bus. The biomass-derived carbon that becomes $\mathrm{CO}_{2}$ leaving the tailpipe is subtracted from the total $\mathrm{CO}_{2}$ emitted by the bus because it is ultimately reused to produce new soybean oil. To ensure that we accurately credit the biodiesel LCI for the amount of recycled $\mathrm{CO}_{2}$, we provide a material balance on biomass carbon.

The material balance shows all the biomass carbon flows associated with the delivery of 1 bhp-h of engine work (Figure 7). For illustration, only the case of $100 \%$ biodiesel is shown. Lower blend rates proportionately lower the amount of biomass carbon credited as part of the recycled $\mathrm{CO}_{2}$. Carbon incorporated in the meal fraction of the soybeans is not included in the carbon balance. Only carbon in the fatty acids and triglycerides used to produce biodiesel are tracked. Not all the carbon incorporated in fatty acids and triglycerides becomes $\mathrm{CO}_{2}$ after biodiesel is combusted. Some oil is lost in the meal by-product. Glycerol is removed from the triglycerides as a by-product. Fatty acids are removed as soaps and waste. Finally, carbon released in combustion ends up as $\mathrm{CO}_{2}, \mathrm{CO}$, THC, and TPM. Of the 169.34 grams of carbon absorbed in the soybean agriculture stage, only 148.39 grams (87\%) end up in biodiesel. After 


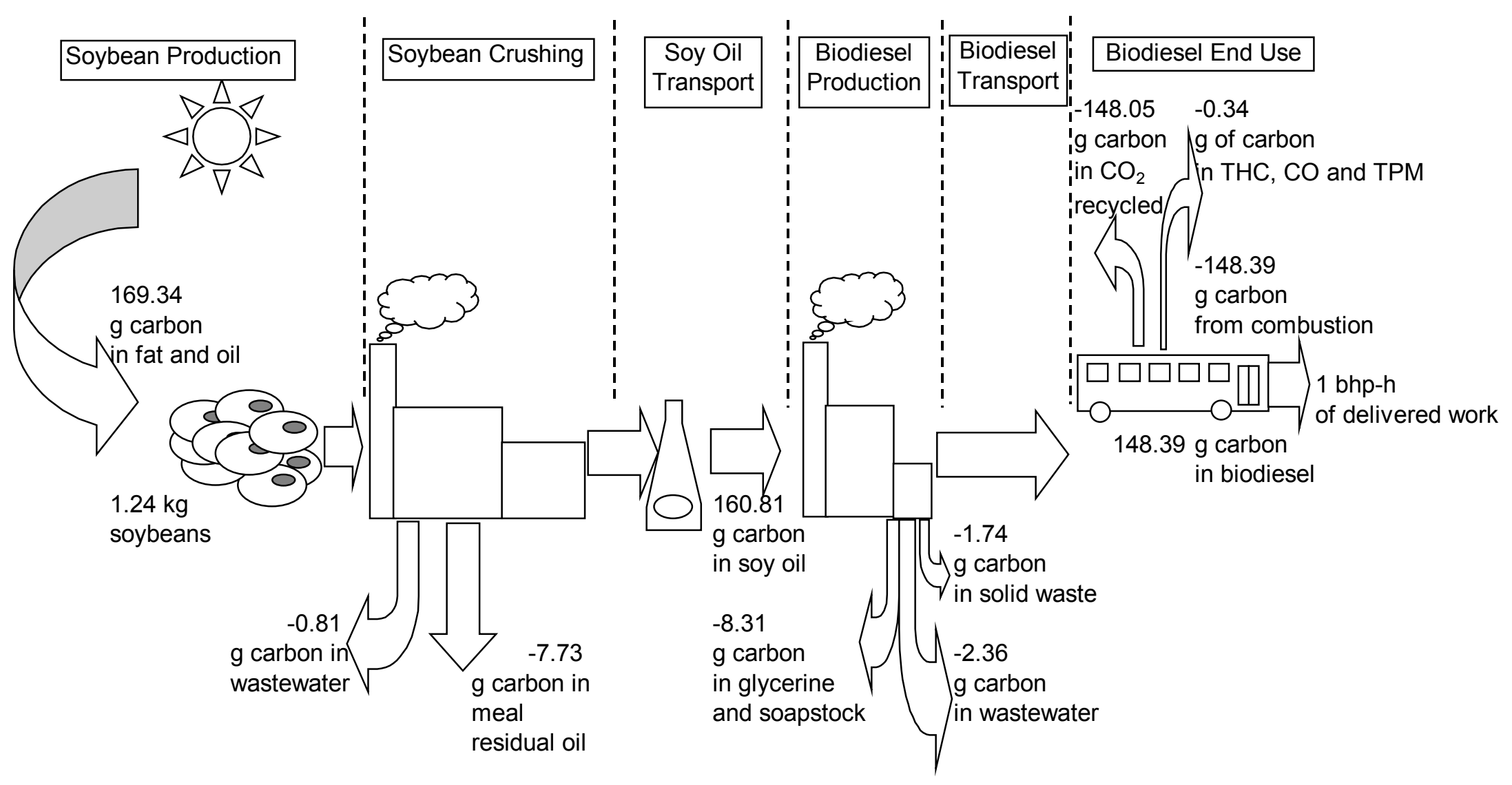

Figure 7: Biomass Carbon Balance for Biodiesel Life Cycle (g carbon/bhp-h) $)^{10}$

${ }^{10}$ All numbers presented as carbon equivalent. To calculate actual $\mathrm{CO}_{2}$ emissions, multiply carbon equivalent numbers by 3.67 (the ratio of the molecular weight of $\mathrm{CO}_{2}$ divided by the molecular weight of carbon). 
accounting for carbon that ends up in other combustion products, 148.05 grams of carbon end up as 543.34 grams of tailpipe $\mathrm{CO}_{2}$. This $\mathrm{CO}_{2}$ is subtracted from the diesel engine emissions as part of the biological recycle of carbon. No credit is taken for the $13 \%$ of the carbon that ends up in various byproducts and waste streams.

\subsubsection{Comparison of $\mathrm{CO}_{2}$ Emissions for Biodiesel and Petroleum Diesel}

Table 7 and Figure 8 summarize $\mathrm{CO}_{2}$ flows from the total life cycles of biodiesel and petroleum diesel and the total $\mathrm{CO}_{2}$ released at the tailpipe for each fuel. The dominant source of $\mathrm{CO}_{2}$ for both the petroleum diesel and the biodiesel life cycles is the combustion of fuel in the bus. For petroleum diesel, $\mathrm{CO}_{2}$ emitted from the tailpipe represents $86.54 \%$ of the total $\mathrm{CO}_{2}$ emitted across the entire life cycle of the fuel. Most remaining $\mathrm{CO}_{2}$ comes from emissions at the oil refinery, which contribute $9.6 \%$ of the total $\mathrm{CO}_{2}$ emissions. For biodiesel, $84.43 \%$ of the $\mathrm{CO}_{2}$ emissions occur at the tailpipe. The remaining $\mathrm{CO}_{2}$ comes almost equally from soybean agriculture, soybean crushing, and soy oil conversion to biodiesel. Figure 9 shows the effect of biodiesel blend levels on $\mathrm{CO}_{2}$ emissions.

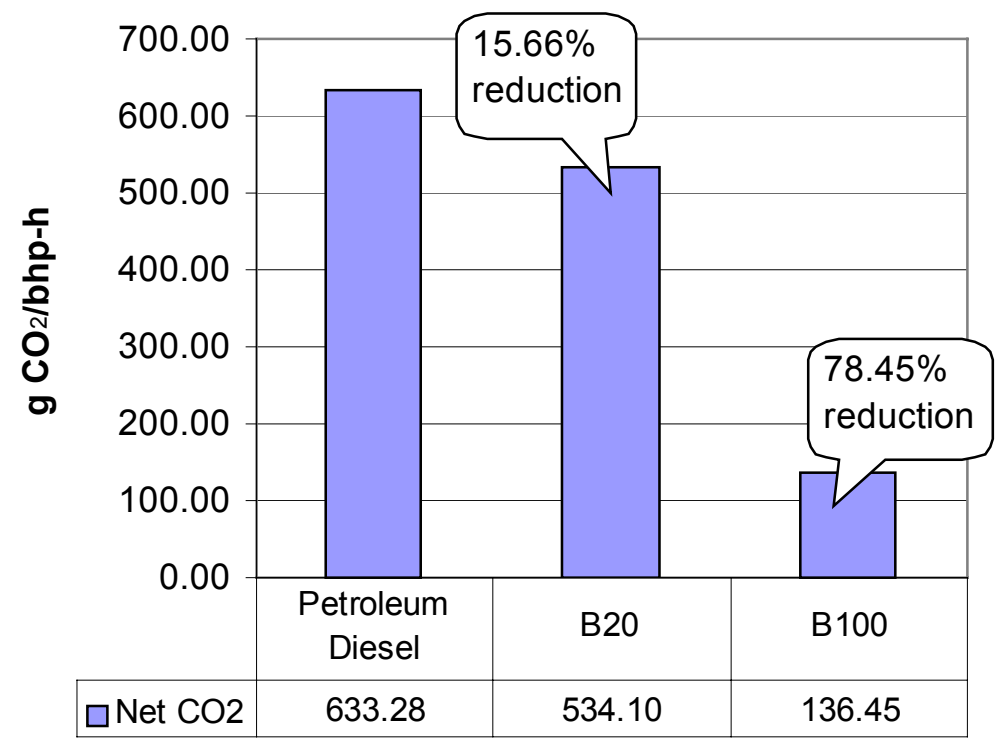

Figure 8: Comparison of Net $\mathrm{CO}_{2}$ Life Cycle Emissions for Petroleum Diesel and Biodiesel Blends ${ }^{11}$

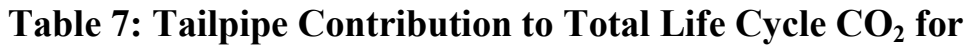
Petroleum Diesel and Biodiesel

(g CO$/$ /bhp-h)

\begin{tabular}{|l|c|c|c|c|c|c|c|}
\hline Fuel & $\begin{array}{c}\text { Total Life } \\
\text { Cycle Fossil } \\
\mathrm{CO}_{2}\end{array}$ & $\begin{array}{c}\text { Total Life } \\
\text { Cycle Biomass } \\
\mathrm{CO}_{2}\end{array}$ & $\begin{array}{c}\text { Total Life } \\
\mathrm{Cycle} \\
\mathrm{CO}_{2}\end{array}$ & $\begin{array}{c}\text { Tailpipe } \\
\text { Fossil } \\
\mathrm{CO}_{2}\end{array}$ & $\begin{array}{c}\text { Tailpipe } \\
\text { Biomass } \\
\mathrm{CO}_{2}\end{array}$ & $\begin{array}{c}\text { Total } \\
\text { Tailpipe } \\
\mathrm{CO}_{2}\end{array}$ & $\begin{array}{c}\text { \% of Total } \\
\mathrm{CO}_{2} \text { from } \\
\text { Tailpipe }\end{array}$ \\
\hline Petroleum Diesel & 633.28 & 0.00 & 633.28 & 548.02 & 0.00 & 548.02 & $86.54 \%$ \\
\hline B100 & 136.45 & 543.34 & 679.78 & 30.62 & 543.34 & 573.96 & $84.43 \%$ \\
\hline
\end{tabular}

${ }^{11}$ Net $\mathrm{CO}_{2}$ calculated by setting biomass $\mathrm{CO}_{2}$ emissions from the tailpipe to zero. 


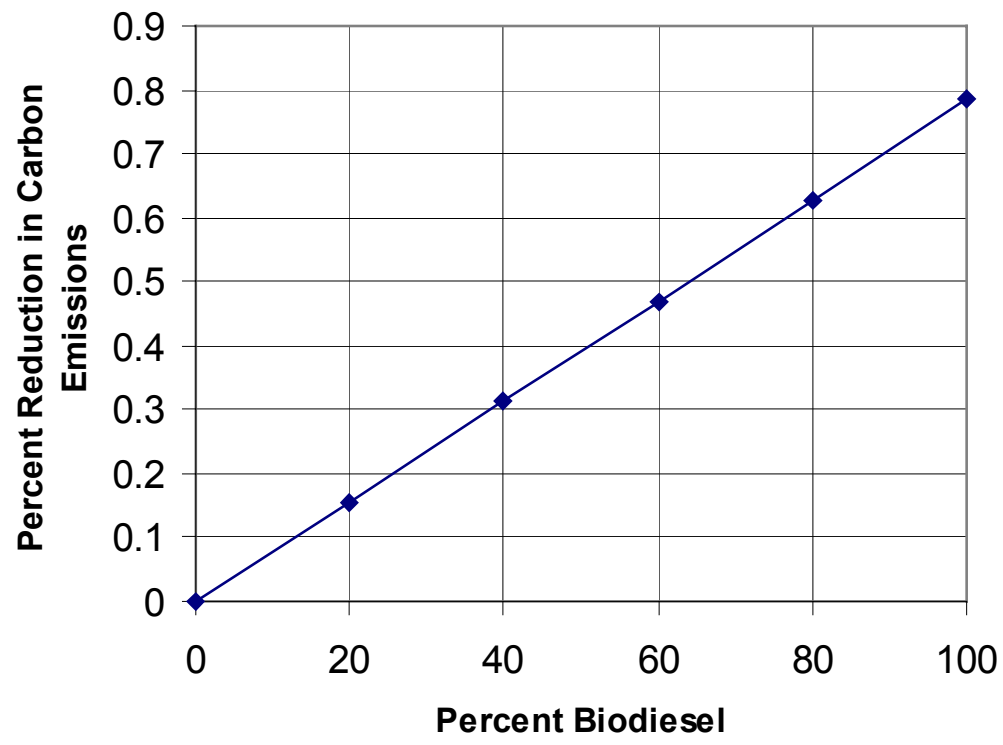

Figure 9: Effect of Biodiesel Blend Level on $\mathrm{CO}_{2}$ Emissions

At the tailpipe, biodiesel (most of which is renewable) emits $4.7 \%$ more $\mathrm{CO}_{2}$ than petroleum diesel. The nonrenewable portion comes from the methanol. Biodiesel generates $573.96 \mathrm{~g} / \mathrm{bhp}-\mathrm{h}$ compared to 548.02 $\mathrm{g} / \mathrm{bhp}$-h for petroleum diesel. The higher $\mathrm{CO}_{2}$ levels result from more complete combustion and the concomitant reductions in other carbon-containing tailpipe emissions. As Figure 8 shows, the overall life cycle emissions of $\mathrm{CO}_{2}$ from $\mathrm{B} 100$ are $78.45 \%$ lower than those of petroleum diesel. The reduction is a direct result of carbon recycling in soybean plants. $\mathrm{B} 20$ reduces net $\mathrm{CO}_{2}$ emissions by $15.66 \%$.

\subsubsection{Primary Resource Consumption for Biodiesel and Petroleum Diesel}

B100 effects a $95 \%$ reduction in life cycle consumption of petroleum. Figure 10 compares petroleum oil consumption for petroleum diesel, B20, and B100. TB20 provides a proportionate reduction of $19 \%$.

Coal and natural gas consumption is a different story (Figure 11). B100 increases life cycle consumption of coal by $19 \%$. This reflects the higher overall demand for electricity in the biodiesel life cycle, relative to petroleum diesel. Electricity demand for soybean crushing is the dominant factor in electricity consumption for biodiesel because of the mechanical processing and solids handling equipment involved. Life cycle consumption of natural gas increases by $77 \%$ for biodiesel versus petroleum diesel. Two factors contribute to this increase: (1) the assumed use of natural gas for the supply of steam and process heat in soybean crushing and soy oil conversion, and (2) the use of natural gas to produce methanol used in the conversion step.

The biodiesel life cycle uses much more water than does the petroleum diesel life cycle. Water use for petroleum diesel is not even visible on a plot scaled to show biodiesel use (Figure 12): the biodiesel life cycle's water use is three orders of magnitude higher. The impact of this water use is not addressed in this report. We offer no simple way to compare water use between the two life cycles because there is no simple equivalency in its use and final disposition. 


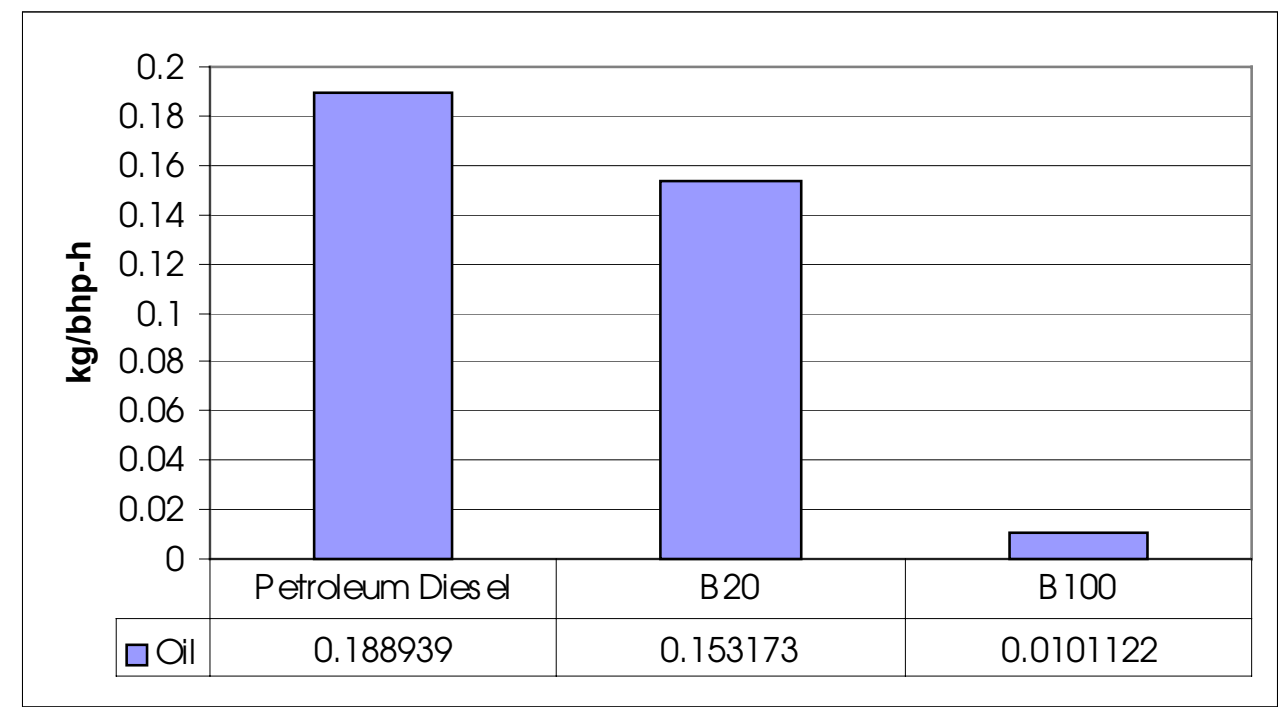

Figure 10: Petroleum Consumption for Petroleum Diesel, B20, and B100

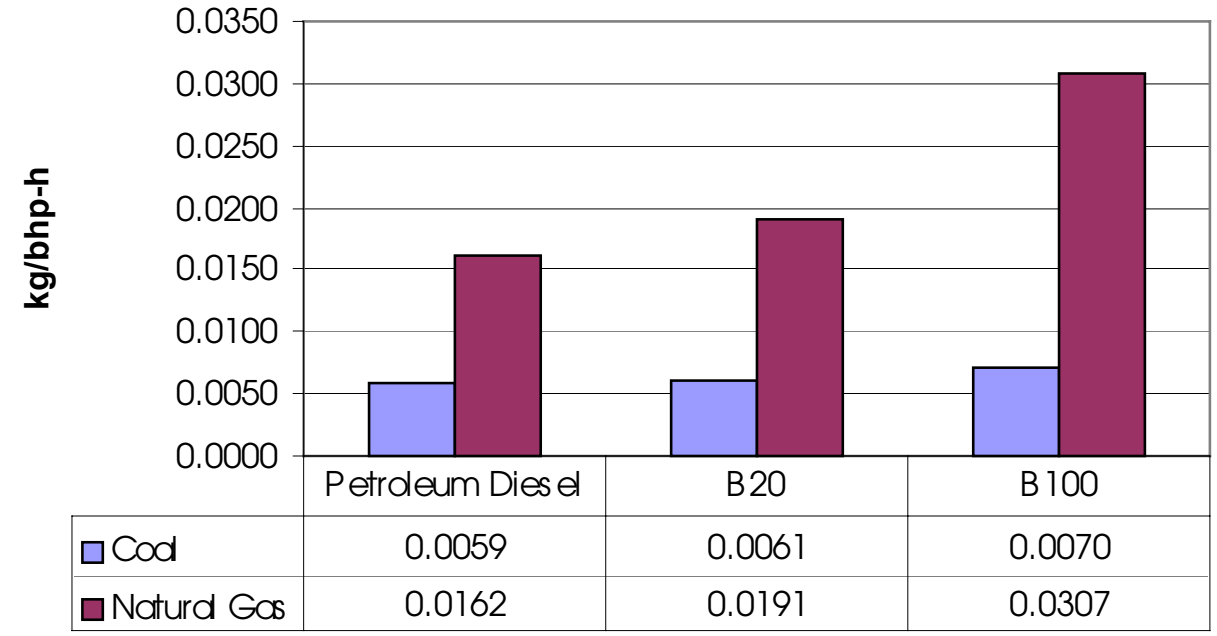

Figure 11: Coal and Natural Gas Consumption for Petroleum Diesel, B20, and B100

\subsubsection{Life Cycle Emissions of Regulated and Nonregulated Air Pollutants}

Regulated air pollutants include the following:

- Carbon Monoxide (CO)

- Nitrogen Oxides $\left(\mathrm{NO}_{\mathrm{x}}\right)$

- Particulate Matter Smaller Than 10 Microns (PM10)

- $\quad$ Sulfur Oxides $\left(\mathrm{SO}_{\mathrm{x}}\right)$

- Non-Methane Hydrocarbons (NMHC) 


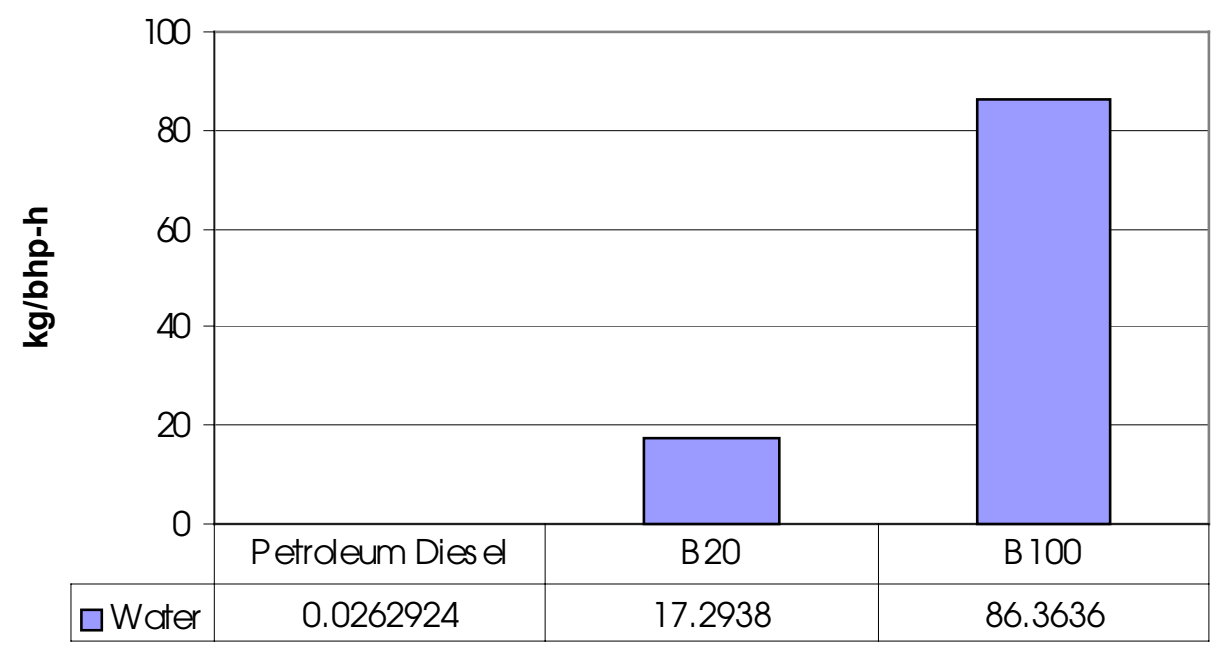

Figure 12: Water Use for Petroleum Diesel, B20, and B100

The emissions of these air pollutants are regulated at the tailpipe for diesel engines. $\mathrm{SO}_{\mathrm{x}}$ has no specific tailpipe limits, but it is controlled through the sulfur content of the fuel. Other air emissions included in this study are $\mathrm{CH}_{4}$, benzene, formaldehyde, nitrous oxide $\left(\mathrm{N}_{2} \mathrm{O}\right)$, hydrochloric acid $(\mathrm{HCl})$, hydrofluoric acid (HF), and ammonia. $\mathrm{N}_{2} \mathrm{O}$ is associated with agricultural field emissions. $\mathrm{HCl}$ and $\mathrm{HF}$ are associated with coal combustion in electric power stations. Ammonia is released primarily during fertilizer production.

In this section, we discuss overall differences in the emissions of the biodiesel and petroleum life cycles. More detail on the sources of the differences is presented in the comprehensive report, Life Cycle Inventories of Biodiesel and Petroleum Diesel for Use in an Urban Bus. Because of variations in how various data sources for the life cycle stages report PM and $\mathrm{HC}$ emissions, we report them differently from the EPA definitions. Benzene and formaldehyde emissions are not consistently reported. Some sources explicitly define emissions for NMHC; others do not specify this distinction. HC data are reported as THC, defined as:

$\mathrm{THC}=\left(\mathrm{CH}_{4}+\right.$ Benzene + formaldehyde $\left.+\mathrm{HC}_{\text {unspecified }}+\mathrm{HC}_{n o \mathrm{CH}} 4\right)$

where:

$$
\begin{aligned}
& \mathrm{THC}=\text { total hydrocarbons } \\
& \mathrm{CH}_{4}=\text { methane } \\
& \mathrm{HC}_{\text {unspecified }}=\text { unspecified hydrocarbons } \\
& \mathrm{HC}_{\mathrm{noCH} 4}=\text { hydrocarbons excluding methane }
\end{aligned}
$$

Likewise, particulates are combined as a single category according to the following formula:

$$
T P M=(P M 10+P M \text { unspecified })
$$

where:

$\mathrm{TPM}=$ total particulate matter

PM10 = particulate matter smaller than 10 microns

$\mathrm{PM}_{\text {unspecified }}=$ unspecified particulate matter 


\subsubsection{Comparison of Life Cycle Air Emissions for Biodiesel and Petroleum Diesel}

Figure 13 summarizes the differences in life cycle air emissions for B100 and B20 versus petroleum diesel fuel. Replacing petroleum diesel with biodiesel in an urban bus reduces life cycle air emissions for all but three of the pollutants we tracked. The largest reduction $(34.5 \%)$ in air emissions that occurs when $\mathrm{B} 100$ or B20 is used as a substitute for petroleum diesel is for CO. The effectiveness of B20 in reducing life cycle emissions of $\mathrm{CO}$ drops proportionately with the blend level. Biodiesel could, therefore, effectively reduce $\mathrm{CO}$ emissions in CO non-attainment areas $^{12}$.

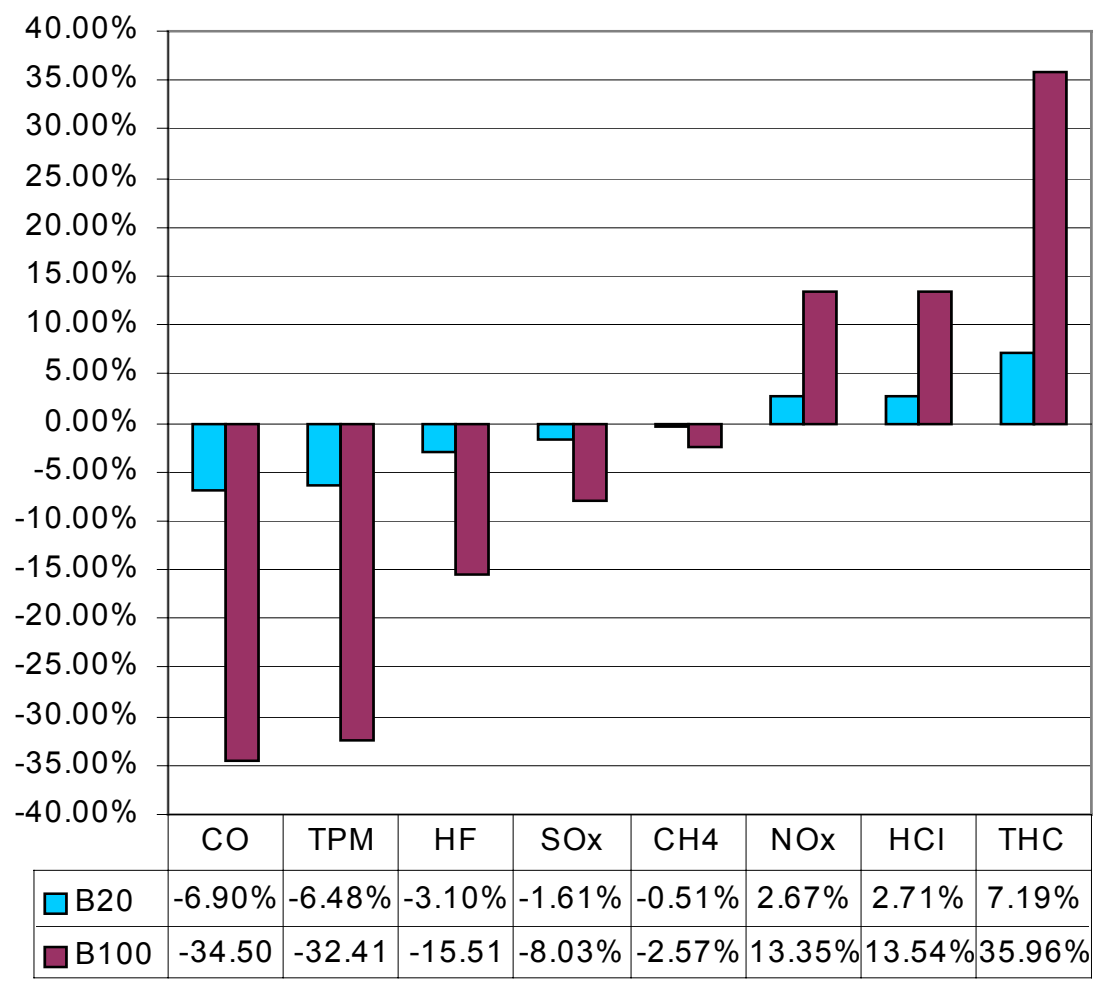

\section{Figure 13: Life Cycle Air Emissions for B100 and B20 Compared to Petroleum Diesel Life Cycle Air Emissions}

B100 exhibits life cycle TPM emissions that are $32.41 \%$ lower than those of the petroleum diesel life cycle. As with $\mathrm{CO}$, the effectiveness of biodiesel in reducing TPM drops proportionately with blend level. This is a direct result of reductions in PM10 at the tailpipe, which are $68 \%$ lower for urban buses operating on B100 versus petroleum diesel. PM10 emitted from mobile sources is a major EPA target because of its role in respiratory disease. Urban areas represent the greatest risk in terms of numbers of people exposed and levels of PM10. Using biodiesel in urban buses may be an option for controlling life cycle emissions of TPM and tailpipe emissions of PM10 $0^{13}$.

\footnotetext{
${ }^{12}$ Urban areas in the United States that do not currently meet National Ambient Air Quality Standards for CO levels.

${ }^{13}$ Among the options EPA is considering, are regulations that would control levels of PM2.5 (particles of 2.5 microns or smaller), as opposed to PM10. That is, EPA is focusing its attention on the very smallest particles in
} 
Biodiesel's life cycle produces $35 \%$ more THC than petroleum diesel's life cycle, even though tailpipe THC emissions for B100 are 37\% lower. Most of the biodiesel life cycle THC emissions are produced during agricultural operations and soybean crushing. To understand the implications of the higher life cycle emissions, it is important to remember that $\mathrm{HC}$ emissions, as with all the air pollutants discussed, have localized effects. Where these emissions occur is important. The fact that biodiesel's tailpipe HC emissions are lower than diesel fuel's may indicate that the biodiesel life cycle has beneficial effects on urban air quality (although diesel engines have very low $\mathrm{HC}$ emission levels and diesel $\mathrm{HC}$ emissions have not been a concern in the past).

Methane $\left(\mathrm{CH}_{4}\right)$ is a special subset of THC emissions and a greenhouse gas. $\mathrm{CH}_{4}$ emissions are $25 \%$ of the life cycle emissions of THC for B100 and 32\% for B20. All occur in the fuel production and use steps and are associated with producing the methanol used to transesterify soy oil. $\mathrm{CH}_{4}$ life cycle emissions are $2.57 \%$ lower for B100 and $0.51 \%$ for B20, compared to petroleum diesel. Though the reductions achieved with biodiesel are small, they could be significant when estimated on the basis of its " $\mathrm{CO}_{2}$ equivalent"warming potential ${ }^{14}$.

Perhaps the next most critical pollutant from the perspectives of human health and environmental quality is $\mathrm{NO}_{\mathrm{x}}$. The triumvirate of $\mathrm{CO}, \mathrm{THC}$, and $\mathrm{NO}_{\mathrm{x}}$ is the key to controlling ground-level ozone and smog in urban areas. Their relative importance is not at all clear because they interact in a complex set of chemical reactions catalyzed by sunlight ${ }^{15}$. Biodiesel effectively reduces tailpipe emissions of $\mathrm{CO}$ and THC. However, both $\mathrm{B} 100$ and $\mathrm{B} 20$ have life cycle and tailpipe emissions of $\mathrm{NO}_{\mathrm{x}}$ that are higher than those of petroleum diesel. B100 and B20 exhibit $13.35 \%$ and $2.67 \%$ higher life cycle emissions, respectively, compared to petroleum diesel. TPM and $\mathrm{NO}_{\mathrm{x}}$ emissions are inversely related in diesel engine exhaust; reducing one often leads to increasing the other. Reducing $\mathrm{NO}_{\mathrm{x}}$ emissions involves a combination of fuel research and engine technology research. Within these two arenas, there may be solutions for meeting the tougher future standards for $\mathrm{NO}_{\mathrm{x}}$ without sacrificing the other benefits of this fuel.

$\mathrm{B} 100$ and $\mathrm{B} 20$ life cycle $\mathrm{SO}_{\mathrm{x}}$ emissions are lower than those of petroleum diesel $(8.03 \%$ and $1.61 \%$, respectively). This is a relatively low reduction given that biodiesel completely eliminates $\mathrm{SO}_{\mathrm{x}}$ at the tailpipe. The amount of $\mathrm{SO}_{\mathrm{x}}$ in the emissions from a diesel engine is a function of sulfur content in the fuel. With this in mind, EPA regulates diesel fuel's sulfur content, rather than tailpipe $\mathrm{SO}_{\mathrm{x}}$ emissions. The latest requirements for diesel fuel include $0.05 \mathrm{wt} \%$ sulfur for on-highway fuel. Biodiesel can eliminate tailpipe $\mathrm{SO}_{\mathrm{x}}$ emissions because it is sulfur-free. On a life cycle basis, the $\mathrm{SO}_{\mathrm{x}}$ emissions eliminated at the tailpipe are offset by creating $\mathrm{SO}_{\mathrm{x}}$ emissions when we produce the electricity used in the biodiesel life cycle.

$\mathrm{HCl}$ and $\mathrm{HF}$ emissions are emitted in very low levels as a part of the life cycles of both petroleum diesel and biodiesel. We tracked them because they may contribute to acidification in the environment. Both pollutants occur as a result of coal combustion in electric power generation. HF levels drop with biodiesel in proportion to the amount of electricity consumed over the life cycle of the fuel. This amounts to $15.51 \%$ reductions for $\mathrm{B} 100 . \mathrm{HCl}$ emissions, on the other hand, increase with biodiesel blend. Biodiesel has additional sources of $\mathrm{HCl}$ associated with the production and use of inorganic acids and bases used in the conversion step. B100 increases emissions of $\mathrm{HCl}$ by $13.54 \%$.

ambient air. Data collected in this study focus on PM10. Our results bode well for lowering levels of PM10, but no information on the effect of biodiesel on this new class of smaller particles is available.

${ }^{14} \mathrm{CH}_{4}$ is a more potent greenhouse gas, but its half-life in the atmosphere is less than that of $\mathrm{CO}_{2}$. These complications illustrate why we have avoided making quantitative judgments about the life cycle impacts of biodiesel. We leave it to others to evaluate the comparative inventories of biodiesel and diesel in terms of their positive and negative impacts.

${ }^{15}$ For an excellent discussion of the complexities of urban air pollution, see Seinfeld, John H., "Urban Air Pollution: State of the Science" in Science 243:745-752. 
The results shown so far describe life cycle emission levels. Many people are also interested in only a subset of life cycle emissions, those being tailpipe emissions. For the reader's convenience, Table 8 provides the data used to model tailpipe emissions for biodiesel, diesel, and B20.

Table 8: Effect of Biodiesel on Tailpipe Emissions (g/bhp-h)

\begin{tabular}{|l|c|c|c|}
\hline \multicolumn{1}{|c|}{ Emission } & $\begin{array}{c}\text { Diesel Fuel } \\
\text { Baseline }\end{array}$ & $\begin{array}{c}20 \% \text { Biodiesel } \\
\text { Blend }\end{array}$ & $\begin{array}{c}100 \% \text { Neat } \\
\text { Biodiesel }\end{array}$ \\
\hline Carbon Dioxide (fossil) & 633.28 & 534.10 & 136.45 \\
\hline Carbon Dioxide (biomass) & 0 & 108.7 & 543.34 \\
\hline Carbon Monoxide & 1.2 & 1.089 & 0.6452 \\
\hline Hydrocarbons & 0.1 & 0.09265 & 0.06327 \\
\hline Particulate Matter (PM10) & 0.08 & 0.0691 & 0.02554 \\
\hline Sulfur Oxides (as $\left.\mathrm{SO}_{2}\right)$ & 0.17 & 0.14 & 0 \\
\hline Nitrogen Oxides $\left(\mathrm{as} \mathrm{NO}_{2}\right)$ & 4.8 & 4.885 & 5.227 \\
\hline
\end{tabular}

\subsubsection{Life Cycle Emissions of Water Effluents}

We tracked a number of waterborne effluents through the life cycles for petroleum diesel and biodiesel such as biological oxygen demand and chemical oxygen demand. However, relatively few data were consistently available. Therefore, comparisons of the two life cycles are limited to total wastewater flow. Foreign and domestic crude oil extraction account for $78 \%$ of the total wastewater flow in the petroleum diesel life cycle. Only about $12 \%$ is associated with the refinery. Two-thirds of the total wastewater flows in the biodiesel life cycle come from the soy oil conversion process. This step generates relatively dilute wastewater that contains oil and soap from soybean oil processing. A comparison of total wastewater flows from the life cycles for petroleum diesel and biodiesel is shown in Figure 14. Petroleum diesel generates roughly five times as much wastewater flow as biodiesel.

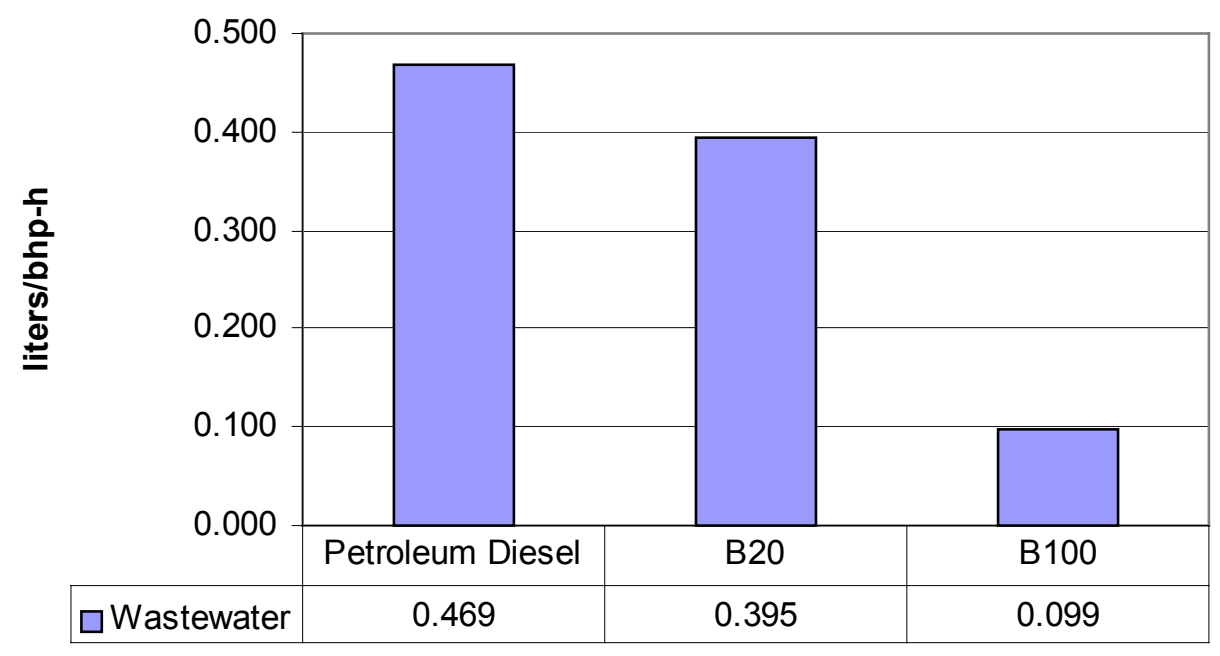

Figure 14: Comparison of Total Wastewater Flows for Petroleum Diesel and Biodiesel Life Cycles 


\subsubsection{Comparison of Solid Waste Life Cycle Flows}

Solid waste from the two life cycles is classified as hazardous or nonhazardous. In the petroleum diesel life cycle, hazardous waste is derived almost entirely from the crude oil refining process. The minor levels of solid waste that show up in foreign crude transport and diesel fuel transport are indirect flows of solid waste attributable to production of diesel fuel and gasoline used in the transportation process. Total hazardous waste generation amounts to $0.41 \mathrm{~g} / \mathrm{bhp}-\mathrm{h}$ of engine work. About half of the nonhazardous waste generated by petroleum diesel is in the crude oil refining step. Another third is generated in the foreign and domestic crude oil extraction steps. Total nonhazardous waste generation in the petroleum diesel life cycle is $2.8 \mathrm{~g} / \mathrm{bhp}-\mathrm{h}$.

Hazardous waste from the biodiesel life cycle amounts to only $0.018 \mathrm{~g} / \mathrm{bhp}-\mathrm{h}$ of engine work. Soybean agriculture contributes $70 \%$ of the hazardous waste from the life cycle, but these flows are indirect charges against agriculture for hazardous waste flows associated with the production of diesel fuel and gasoline used on the farm. Nonhazardous solid waste generated in the biodiesel life cycle is $12.7 \mathrm{~g} / \mathrm{bhp}-\mathrm{h}$ of engine work. This waste is primarily trash and tramp metals removed from soybeans brought into the soybean crushing stage. Figure 15 and Figure 16 show hazardous and nonhazardous solid waste generation for petroleum diesel and biodiesel. The B100 life cycle produces $96 \%$ less hazardous waste compared to petroleum diesel life cycle. Nonhazardous waste, on the other hand, is twice as high for B100.

\subsection{Sensitivity Studies}

\subsubsection{The Effect of Enhanced Location for Biodiesel Production and Use}

We studied the effect of placing biodiesel production and use in a more optimal location, which mimics how similar renewable fuels industries, such as ethanol, have developed. We therefore modeled biodiesel production and use in the Chicago area, which provides a good outlet for biodiesel sales for the urban bus end use. More importantly, it allows us to consider near-term access to some of the best soybean farmland in the United States. This scenario reduces the distances required to move beans, oil, and biodiesel, and allows us to take advantage of high-yield soybean agriculture.

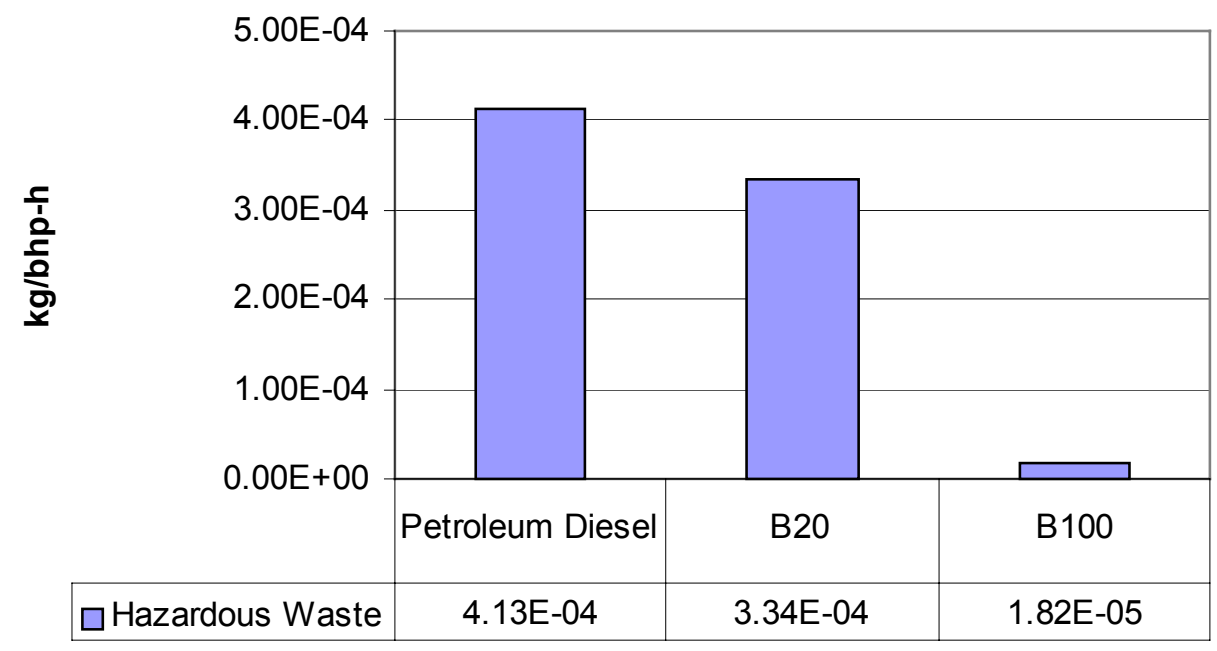

Figure 15: Hazardous Waste Generation for Petroleum Diesel, B20, and B100 


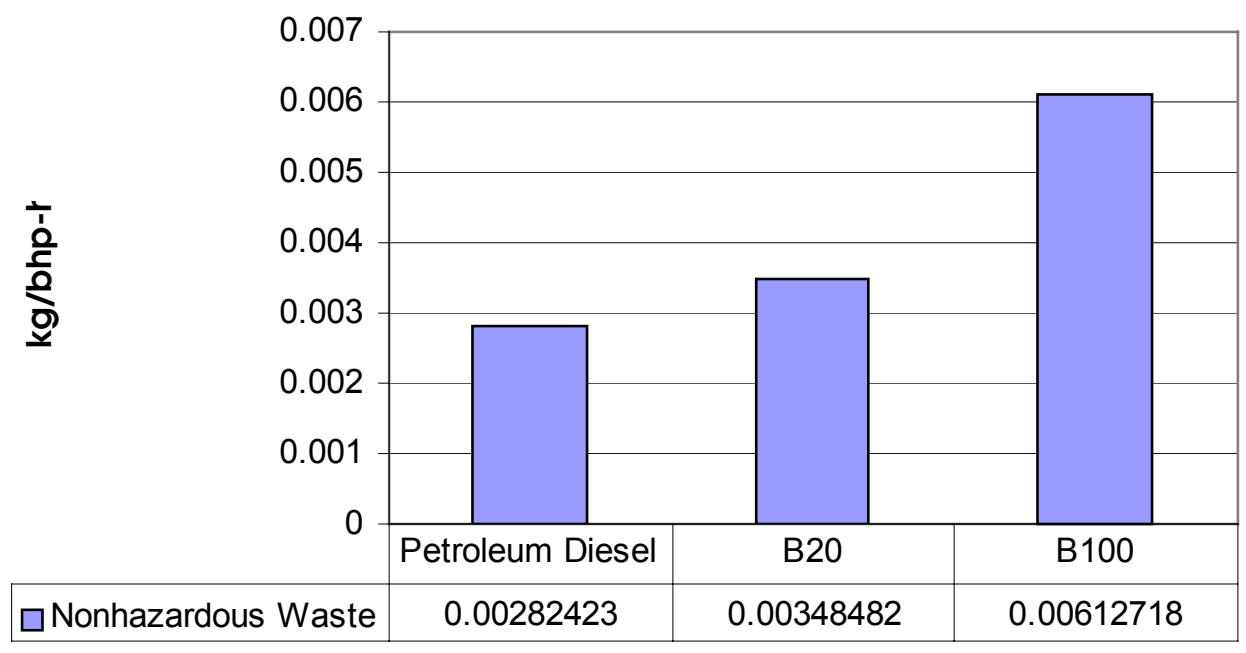

Figure 16: Nonhazardous Waste Generation for Petroleum Diesel, B20, and B100

Basic changes to the model are shown inTable 9. The reduced distance for shipping soybean oil is based on an evaluation of the location of crushing facilities to potential market locations. The results of the model with these assumptions is presented for B100 (the improvements or worsening in life cycle emissions relative to petroleum diesel are proportional to the blend level).

Placing biodiesel production and use in the Chicago area has benefits for energy consumption (see Figure 17). Impacts on natural gas and coal consumption are minor (2\% and $5 \%$ savings, respectively). Petroleum consumption, on the other hand, drops by $23.53 \%$ from the national average base case. This leads to a slight increase in life cycle energy efficiency from the base case value of $80.55 \%$ to $81.84 \%$. Biodiesel's fossil energy ratio increases from 3.22 to 3.43 . The energy savings occur primarily on the farm. Process energy requirements for farming drop by $22 \%$. Energy savings of $56 \%$ are also realized in the soy oil transport step, but this impact is smaller because of the relatively small contribution to energy demand made by this step. Water use drops dramatically (31\%) in the Chicago area scenario.

Table 9: Model Parameters for the Chicago Area Biodiesel Scenario

\begin{tabular}{|l|l|l|}
\hline Model Parameter & \multicolumn{1}{|c|}{ Baseline Scenario } & \multicolumn{1}{c|}{ Chicago Area Scenario } \\
\hline $\begin{array}{l}\text { Soybean } \\
\text { Agriculture }\end{array}$ & $\begin{array}{l}\text { Yields and inputs based on national average } \\
\text { (14 key soybean-producing states) }\end{array}$ & $\begin{array}{l}\text { Yields and inputs based on } \\
\text { production of soybeans from } \\
\text { Illinois and Iowa. 50\% of soybean } \\
\text { supply is taken from each state. }\end{array}$ \\
\hline $\begin{array}{l}\text { Transport } \\
\text { Distances }\end{array}$ & $\begin{array}{l}\text { National average distance for soy oil of 571 } \\
\text { miles }\end{array}$ & $\begin{array}{l}\text { Reduced travel distance of 248 } \\
\text { miles. }\end{array}$ \\
\hline
\end{tabular}

The percent reductions of key air pollutants are tabulated in Figure 18. The change to a more favorable location has modest benefits for air emissions. The exception is for ammonia emissions, which drop by $45 \%$. Ammonia emissions occur as a result of nitrogen fertilizer use. The large drop in life cycle ammonia emissions is due to improved yields and lower nitrogen fertilizer use rates per $\mathrm{kg}$ of soybeans produced. The next largest saving is for PM10 emissions, which drop 10\% from the base case. This is consistent 


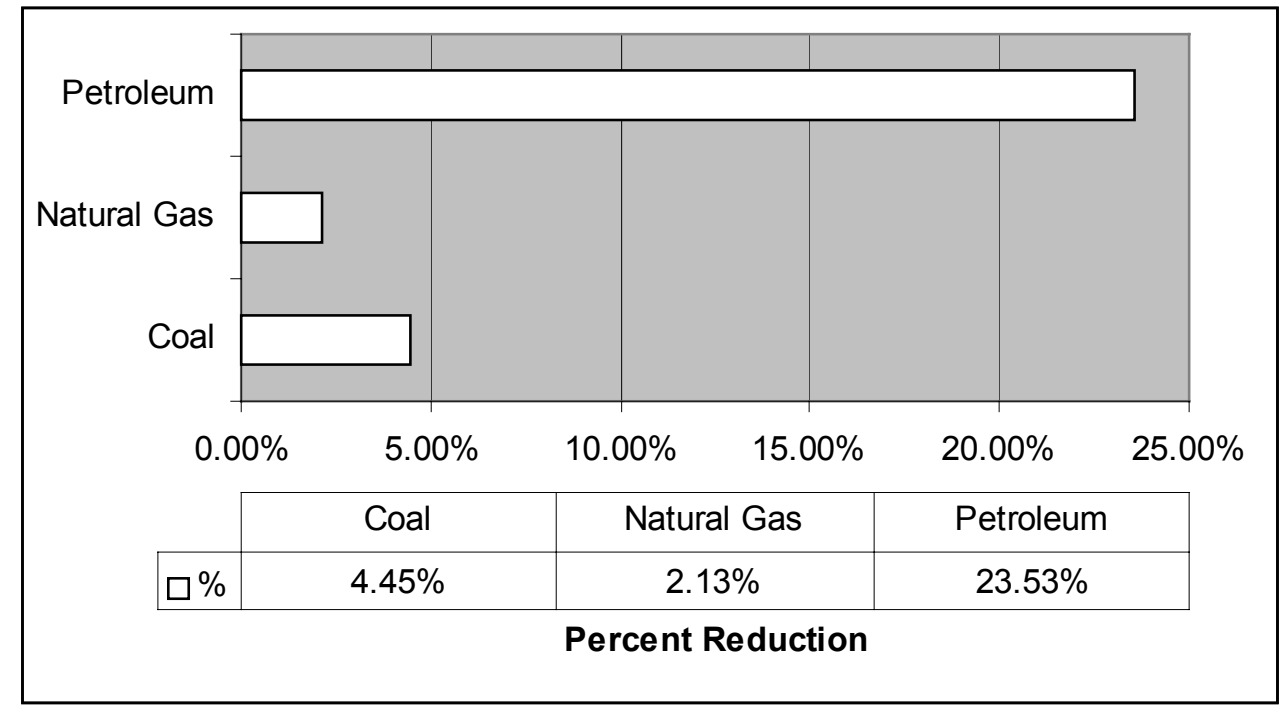

Figure 17: The Effect of an Enhanced Location for Biodiesel on Life Cycle Consumption of Primary Energy Resources

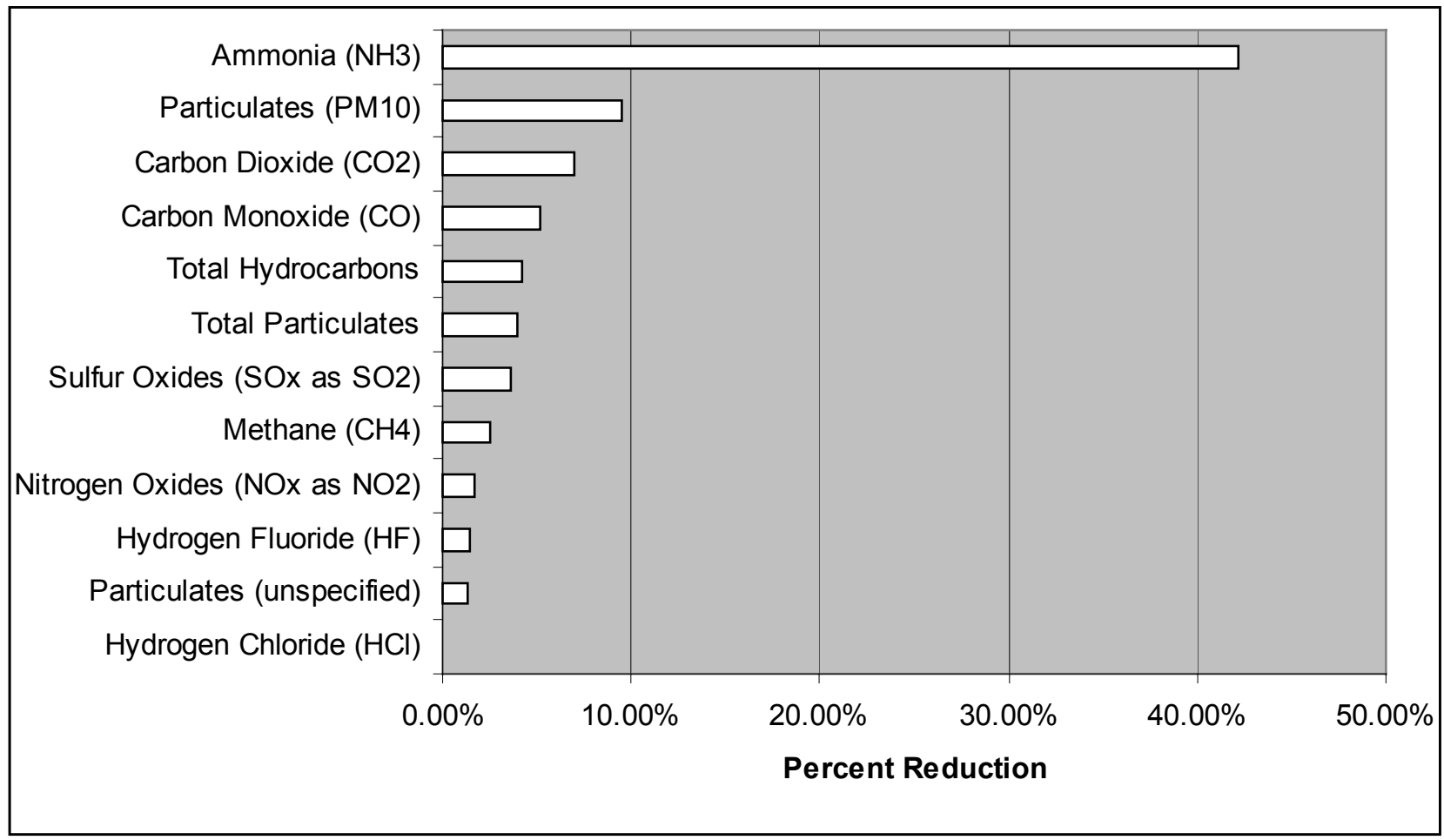

Figure 18 : Reductions in Life Cycle Air Emissions for the Chicago Area Biodiesel Scenario 


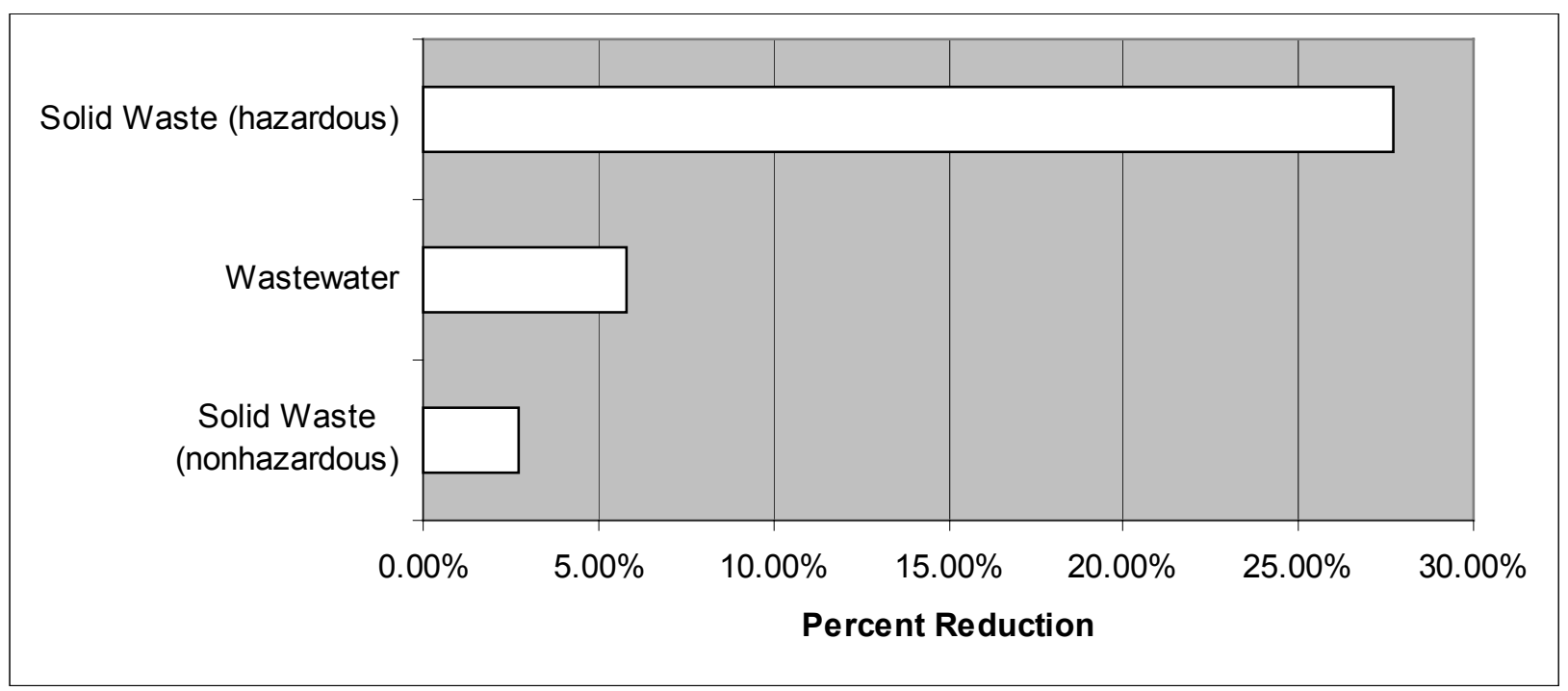

Figure 19: Water and Solid Waste Emissions Reductions for the Chicago Area Biodiesel Scenario

with the reductions in petroleum consumption associated with diesel fuel use on the farm. The Chicago scenario provides an additional savings of $7 \%$ in $\mathrm{CO}_{2}$ emissions. All other emissions savings are less than $5 \%$, compared to the base case.

Reductions in life cycle waste emissions are shown in Figure 19. Hazardous waste emissions are reduced dramatically. The $28 \%$ reduction corresponds to lower levels of diesel fuel use in soybean farming. Wastewater is reduced by $5.79 \%$; nonhazardous solid wastes by $2.72 \%$.

\subsubsection{The Effect of Energy Requirements for Conversion of Soybean Oil to Biodiesel}

A range of energy inputs for converting soybean oil to biodiesel was used in the LCI model to test the effect of these modeling assumptions on the overall LCI of biodiesel. A survey of current commercial technology for biodiesel reveals a high degree of variation on reported steam and electricity requirements for the transesterification process. High and low estimates for both steam and electricity used in the model are indicated in Table 10.

Table 10: Range of Energy Inputs for Soybean Oil Conversion Tested in LCI Model

\begin{tabular}{|l|c|c|c|}
\hline \multicolumn{1}{|c|}{ Energy Use } & Low Value & Baseline Scenario & High Value \\
\hline Steam (kcal/metric ton of biodiesel produced) & $95,022.7$ & $329,793.5$ & $617,922.2$ \\
\hline Electricity (kWh/metric ton of biodiesel produced) & 9.0 & 28.9 & 40.0 \\
\hline
\end{tabular}

Steam requirements vary 3.5-fold from the lowest to the highest value. Electricity varies 4.4-fold. This high degree of variability warrants testing the range of our assumptions to assess the uncertainty of our pertinent results. Also, energy inputs for soybean oil conversion comprise a substantial part of the life cycle, and make this variability even more important.

The effect of conversion energy variability on the demand for primary energy resources is shown in Figure 20. Overall effects on primary energy are considerably smaller than the range of variation in energy inputs. Oil consumption is unaffected. Because natural gas is the sole source of process energy in the conversion model, it is the most affected by the energy requirements assumed for this stage. Natural 
gas consumption increases $16.41 \%$ for the high energy inputs and decreases by $13.5 \%$ for the low energy inputs. Coal consumption ranges from $+6.55 \%$ to $-11.7 \%$ of the base case.

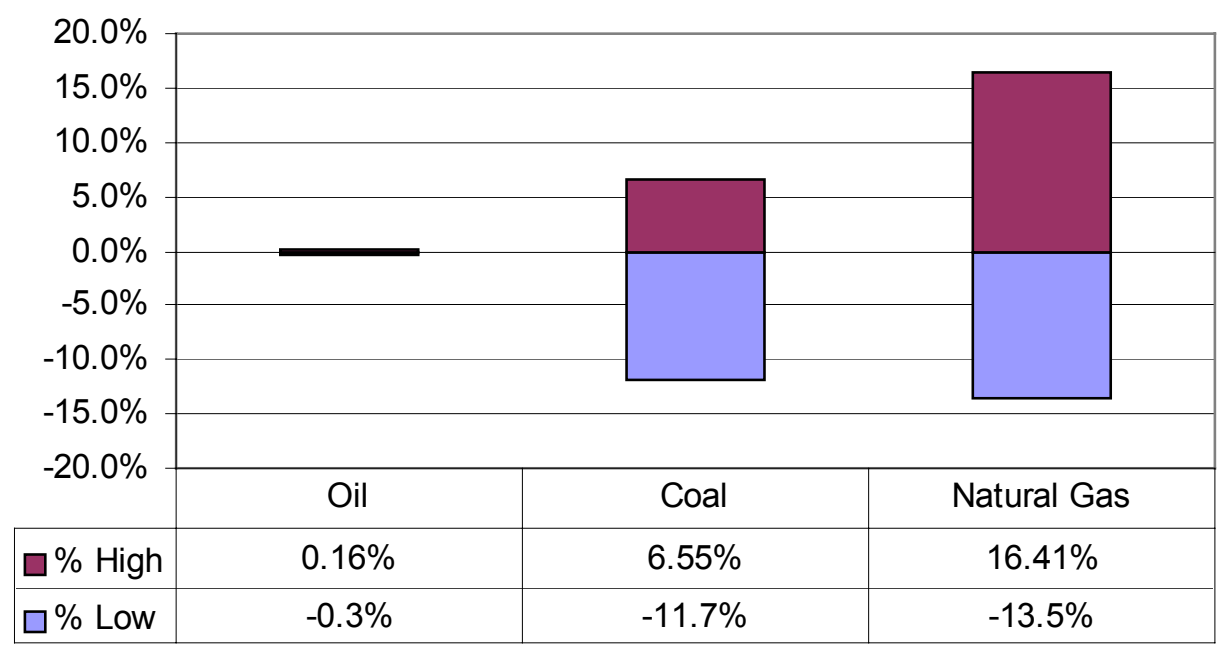

\section{Figure 20: The Effect of Conversion Energy Requirements on Primary Energy Resource Demands for Biodiesel}

Figure 21 presents changes in biodiesel's life cycle air emissions across the range of assumed energy requirements for soybean oil conversion. Life cycle emissions are listed in order of increasing sensitivity to energy requirement assumptions. Changes in steam requirements (and hence natural gas consumption) strongly affect $\mathrm{CH}_{4}$ emissions, which can vary by $14 \%$ in both directions. From a greenhouse gas perspective, this is probably the most significant change observed in this sensitivity study. $\mathrm{CO}_{2}$ shows similar responses. Unspecified $\mathrm{PM}$ and $\mathrm{SO}_{\mathrm{x}}$ emissions are also affected significantly, reflecting emissions from combustion for electricity generation. The other emissions show little response to the energy inputs for soy oil conversion.

The relative changes in solid waste and wastewater emissions are presented in Figure 22. Wastewater and hazardous solid waste emissions change little across the range of assumed energy requirements. Nonhazardous solid waste shows a moderate response. 


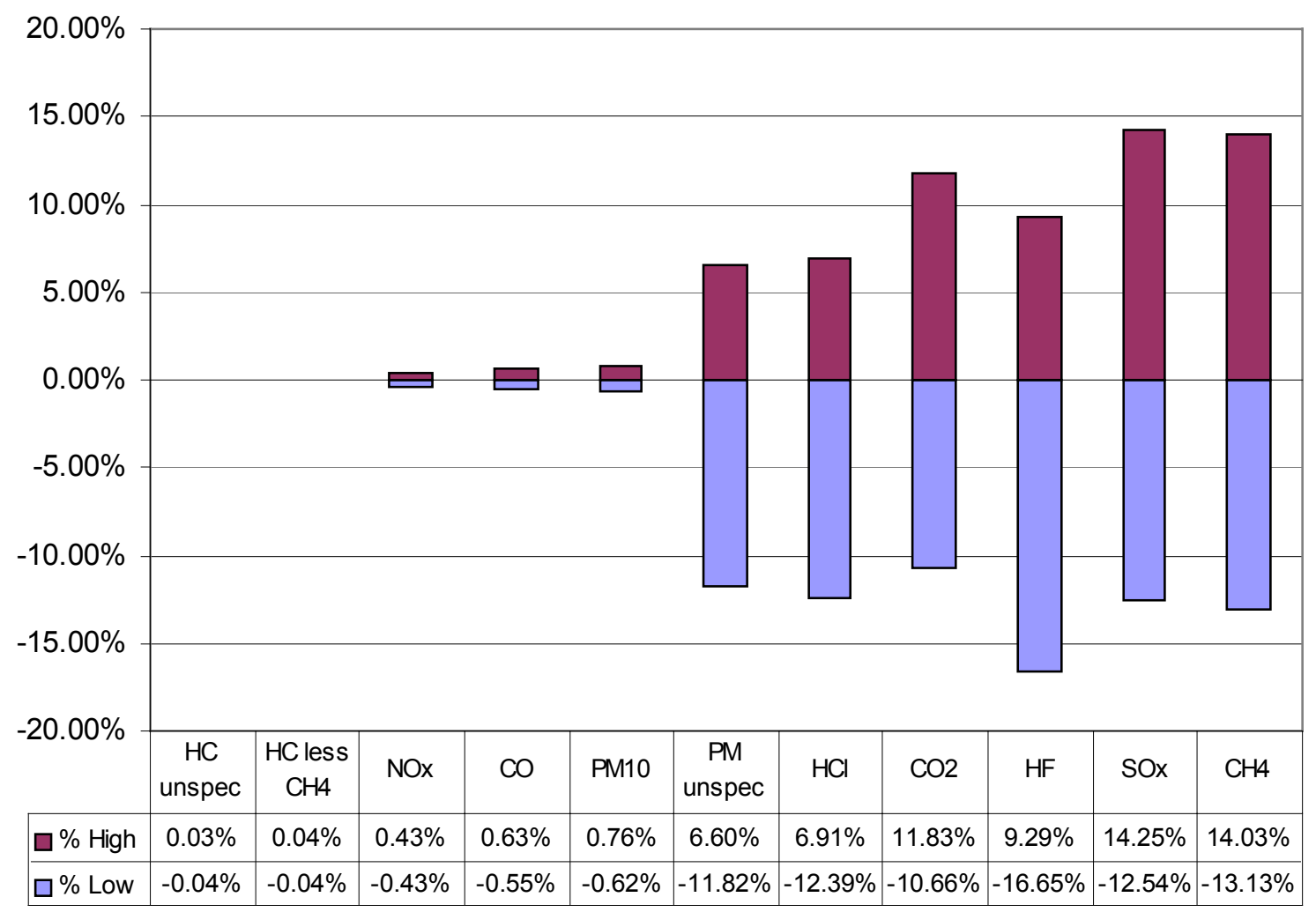

Figure 21: The Effect of Soybean Oil Conversion Energy Demands on Air Emissions for Biodiesel

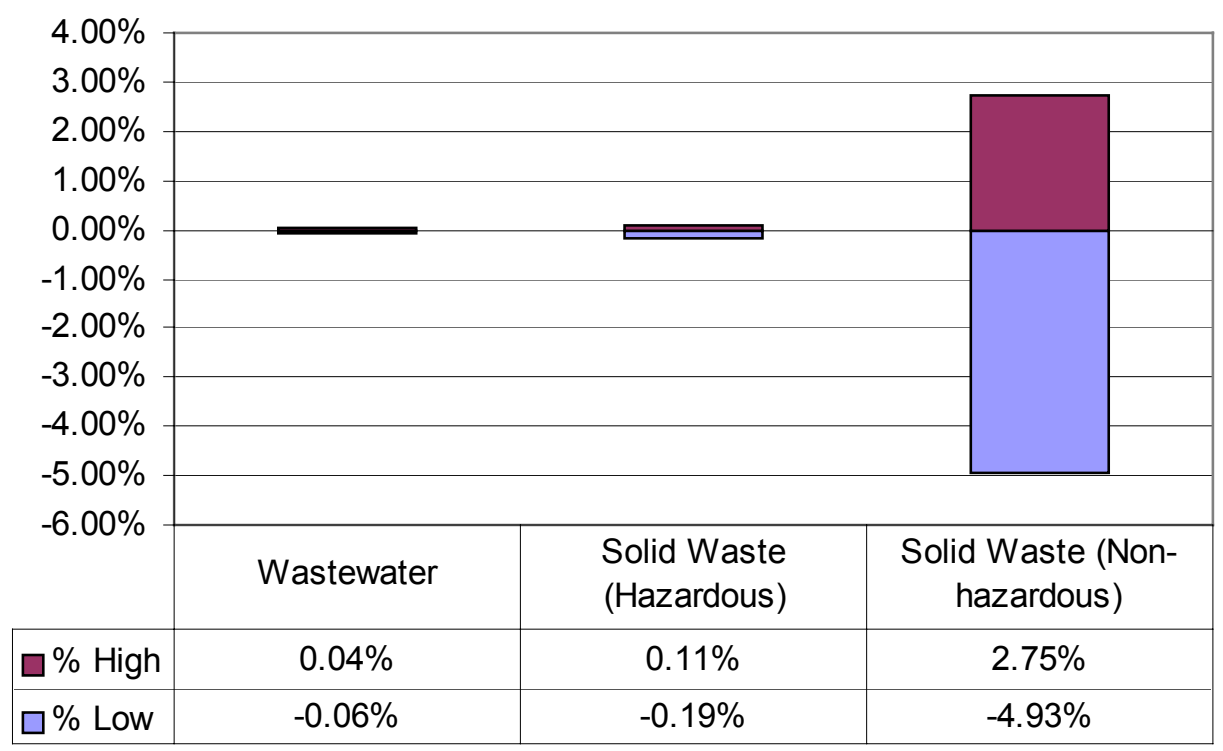

Figure 22: The Effect of Soybean Oil Conversion Energy Demands on Water and Solid Waste Emissions for Biodiesel 
Conducting LCIs is fraught with difficulties. Incomplete data are the rule rather than the exception, so we have varying degrees of confidence in our results. The most complete data, and hence the most reliable conclusions, are for overall energy balance and $\mathrm{CO}_{2}$ emissions. More importantly, our sensitivity studies show that the estimates of $\mathrm{CO}_{2}$ emissions and energy requirements are very robust; that is, they show little change in response to changes in key assumptions.

\subsection{Life Cycle Energy and Environmental Flows}

Major analytical results are presented below in order of decreasing confidence:

- Energy Balance. Biodiesel and petroleum diesel have very similar energy efficiencies. The base-case model estimates life cycle energy efficiencies of $80.55 \%$ for biodiesel versus $83.28 \%$ for petroleum diesel. The lower efficiency for biodiesel reflects slightly higher process energy requirements for converting the energy contained in soybean oil to fuel. In terms of effective use of fossil energy resources, biodiesel yields around 3.2 units of fuel product energy for every unit of fossil energy consumed in the life cycle. By contrast, petroleum diesel's life cycle yields only 0.83 units of fuel product energy per unit of fossil energy consumed. Such measures confirm the "renewable" nature of biodiesel. The life cycle for B20 has a proportionately lower fossil energy ratio (0.98 units of fuel product energy for every unit of fossil energy consumed). B20's fossil energy ratio reflects the impact of adding petroleum diesel into the blend.

- Carbon Dioxide Emissions. The demand for fossil energy associated with biodiesel is low, so its life cycle emissions of $\mathrm{CO}_{2}$ are, not surprisingly, much lower. Per unit of work delivered by a bus engine, $\mathrm{B} 100$ reduces net $\mathrm{CO}_{2}$ emissions by $78.45 \%$ compared to petroleum diesel. B20's life cycle $\mathrm{CO}_{2}$ emissions are $15.66 \%$ lower. Thus, replacing petroleum diesel with biodiesel in urban buses is an extremely effective strategy for reducing $\mathrm{CO}_{2}$ emissions.

- Total Particulate Matter and Carbon Monoxide Emissions. The B100 life cycle produces 32\% less TPM and 35\% less CO than the petroleum diesel life cycle. Most occur because of lower emissions at the tailpipe. PM10 emissions from an urban bus operating on biodiesel are $68 \%$ lower than those from an urban bus operating on petroleum diesel. Biodiesel reduces tailpipe $\mathrm{CO}$ emissions by $46 \%$.

- Nitrogen Oxide Emissions. At the same time, $\mathrm{NO}_{\mathrm{x}}$ emissions are 13\% higher for the B100 life cycle compared to the petroleum diesel life cycle. B20 has $2.67 \%$ higher life cycle emissions of $\mathrm{NO}_{\mathrm{x}}$. Again, this increase is attributed to higher $\mathrm{NO}_{\mathrm{x}}$ emissions at the tailpipe. An urban bus run on $\mathrm{B} 100$ has $\mathrm{NO}_{\mathrm{x}}$ emissions that are $8.89 \%$ higher than a bus operated on petroleum diesel.

- Total Hydrocarbons. We also report 35\% higher life cycle emissions of THC compared to petroleum diesel, but tailpipe THC emissions are 37\% lower for B100 than for petroleum diesel. The increase results from hexane being released during soybean processing and to volatilization of agrochemicals applied on the farm. We have less 
confidence in the $\mathrm{HC}$ air emissions results from this study. Air emissions data are often not reported on the same basis. For example, data run the gamut from specific HC compounds such as $\mathrm{CH}_{4}$ or benzene to broad measures of THCs, which are not measured consistently. Our data set includes numbers reported as unspecified HCs and as NMHCs. We therefore view these data with caution.

- Water and Solid Waste. We report total wastewater and solid waste flows. Our results show that biodiesel life cycle wastewater flows are almost $80 \%$ lower than those of petroleum diesel. Biodiesel is also responsible for only about $5 \%$ of the hazardous waste generated by petroleum diesel. However, we do not have a consistent basis for comparing these flows because their final disposition and composition are so different.

- Water Consumption. On a life cycle basis, B100 uses water at a level that is three orders of magnitude higher than petroleum diesel.

\subsection{Next Steps}

We designed this study to identify and quantify the advantages of biodiesel as a substitute for petroleum diesel. These advantages are substantial, especially in the area of energy security and greenhouse gas control. We have also identified weaknesses or areas of concern for biodiesel-such as its $\mathrm{NO}_{\mathrm{x}}$ and $\mathrm{THC}$ emissions. We see these as opportunities for further research. We hope our findings will be used to focus future biodiesel research on these critical issues.

Next steps for this work include:

$\checkmark$ Use the LCI to assess the relative environmental and public health effects of petroleum diesel and biodiesel to better understand the benefits associated with biodiesel.

$\checkmark$ Quantify the costs and benefits of biodiesel.

$\checkmark$ Assess the economic impact of biodiesel as an alternative fuel (e.g., its effects on jobs and the trade deficit).

$\checkmark$ Evaluate other feedstock sources.

$\checkmark$ Incorporate new health effects data on emissions from biodiesel and petroleum diesel.

$\checkmark$ Develop regional life cycle models for biodiesel use.

$\checkmark$ Evaluate performance of newer diesel engines and new fuel production technologies.

This study provides the building blocks for assessing the relative merits of this fuel under a wide variety of circumstances. It also provides information that local regulators seek when developing approaches to solving our air, water, and solid waste problems. We leave it to these individuals to use this information to customize their evaluations of their particular questions. We ask only that it be used wisely. 


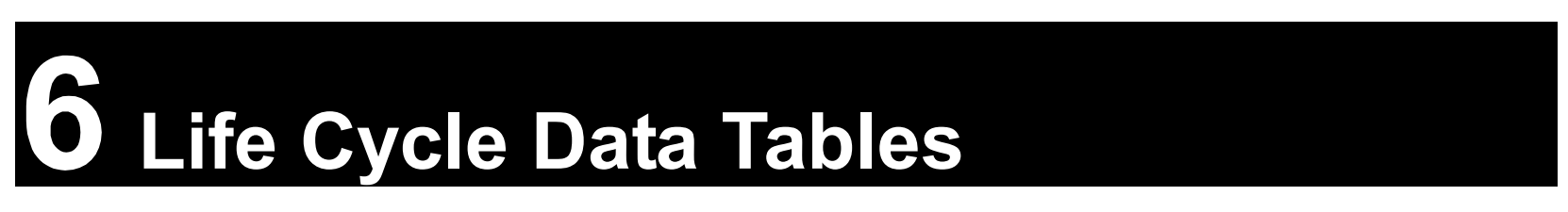

The life cycle analysis produced data describing each major step in the production and use of biodiesel and diesel fuel. These tables are provided here to aid the reader in understanding where various emissions and inputs occurred during the life cycles. In order to understand these tables the following issues need to be considered. First, all the inputs and outflows associated with each step in the life cycles are shown as units per brake horsepower hour of diesel engine service. Second, these data have already been "allocated;" in other words, if a process creates two products, the inputs (energy, chemicals, feedstocks) and the emissions (air, water, solid wastes) have been divided up between the two products based on a mass allocation. Only the fraction of the inputs and emissions that have been allocated to diesel fuel and biodiesel are shown. Third, some inputs, such as electricity, are not shown directly. Instead, the raw materials consumed to make the electricity are shown. So instead of electricity, you will see estimates of coal, natural gas, or uranium inputs. Lastly, the degree of accuracy shown, e.g., number of spaces right of a decimal point, are not indicative of the confidence we place in the number itself. The degree of accuracy shown provides an opportunity for another researcher to reproduce our numbers. Our confidence in how accurately the number reflects actual industry averages may be quite different, and has been described in earlier sections. For more information, please see the detailed, comprehensive report, Life Cycle Inventories of Biodiesel and Petroleum Diesel for Use in an Urban Bus.

The life cycle tables are provided in the following order: energy efficiency, carbon balance, inputs, and air emissions. 
Table 11: Primary Energy Demand for the Petroleum Diesel Life Cycle Inventory

\begin{tabular}{|l|c|c|}
\hline \multicolumn{1}{|c|}{ Stage } & Primary Energy (MJ per MJ of Fuel) & Percent \\
\hline Domestic Crude Production & 0.5731 & $47.73 \%$ \\
\hline Foreign Crude Oil Production & 0.5400 & $44.97 \%$ \\
\hline Domestic Crude Transport & 0.0033 & $0.28 \%$ \\
\hline Foreign Crude Transport & 0.0131 & $1.09 \%$ \\
\hline Crude Oil Refining & 0.0650 & $5.41 \%$ \\
\hline Diesel Fuel Transport & 0.0063 & $0.52 \%$ \\
\hline Total & 1.2007 & $100.00 \%$ \\
\hline
\end{tabular}

Table 12: Fossil Energy Requirements for the Petroleum Diesel Life Cycle

\begin{tabular}{|l|c|l|}
\hline \multicolumn{1}{|c|}{ Stage } & Fossil Energy (MJ per MJ of Fuel) & Percent \\
\hline Domestic Crude Production & 0.572809 & $47.75 \%$ \\
\hline Foreign Crude Oil Production & 0.539784 & $45.00 \%$ \\
\hline Domestic Crude Transport & 0.003235 & $0.27 \%$ \\
\hline Foreign Crude Transport & 0.013021 & $1.09 \%$ \\
\hline Crude Oil Refining & 0.064499 & $5.38 \%$ \\
\hline Diesel Fuel Transport & 0.006174 & $0.51 \%$ \\
\hline Total & 1.199522 & $100.00 \%$ \\
\hline
\end{tabular}


Table 13: Primary Energy Requirements for Biodiesel Life Cycle

\begin{tabular}{|l|c|r|}
\hline Stage & Primary Energy (MJ per MJ of Fuel) & \multicolumn{1}{|c|}{ Percent } \\
\hline Soybean Agriculture & 0.0660 & $5.32 \%$ \\
\hline Soybean Transport & 0.0034 & $0.27 \%$ \\
\hline Soybean Crushing & 0.0803 & $6.47 \%$ \\
\hline Soy Oil Transport & 0.0072 & $0.58 \%$ \\
\hline Soy Oil Conversion & 1.0801 & $87.01 \%$ \\
\hline Biodiesel Transport & 0.0044 & $0.35 \%$ \\
\hline Total & 1.2414 & $100.00 \%$ \\
\hline
\end{tabular}

Table 14: Fossil Energy Requirements for the Biodiesel Life Cycle

\begin{tabular}{|l|c|r|}
\hline Stage & Fossil Energy (MJ per MJ of Fuel) & Percent \\
\hline Soybean Agriculture & 0.0656 & $21.08 \%$ \\
\hline Soybean Transport & 0.0034 & $1.09 \%$ \\
\hline Soybean Crushing & 0.0796 & $25.61 \%$ \\
\hline Soy Oil Transport & 0.0072 & $2.31 \%$ \\
\hline Soy Oil Conversion & 0.1508 & $48.49 \%$ \\
\hline Biodiesel Transport & 0.0044 & $1.41 \%$ \\
\hline Total & 0.3110 & $100.00 \%$ \\
\hline
\end{tabular}


Table 15: Biomass Carbon Balance for Biodiesel Life Cycle (g/bhp-h) ${ }^{16}$

\begin{tabular}{|l|r|r|}
\hline Life Cycle Stage & g carbon per bhp-h & $\mathrm{g} \mathrm{CO}_{2} /$ bhp-h \\
\hline Soybean Production & $\mathbf{1 6 9 . 3 4}$ & $\mathbf{6 2 1 . 4 8}$ \\
\hline $\begin{array}{l}\text { Uptake of carbon in triglycerides and fatty } \\
\text { acids }\end{array}$ & 169.34 & 621.48 \\
\hline Soybean Crushing & $\mathbf{1 6 0 . 8 1}$ & $\mathbf{5 9 0 . 1 6}$ \\
\hline Release of carbon via residual oil in meal & $\mathbf{( 7 . 7 3 )}$ & $(28.36)$ \\
\hline Release of carbon via waste & $(0.81)$ & $(2.97)$ \\
\hline Biodiesel Production & $\mathbf{1 4 8 . 3 9}$ & $\mathbf{5 4 4 . 6 0}$ \\
\hline Release of carbon via glycerine & $(8.26)$ & $(30.32)$ \\
\hline Release of carbon via wastewater & $(2.36)$ & $(8.67)$ \\
\hline Release of carbon via solid waste & $(1.74)$ & $(6.40)$ \\
\hline Release of carbon in soapstock & $(0.05)$ & $(0.17)$ \\
\hline Combustion in bus & & - \\
\hline Release of carbon in biodiesel (total) & $(148.39)$ & $(544.60)$ \\
\hline Release of carbon in CO & $(148.05)$ & $(543.34)$ \\
\hline Release of carbon in HC & $(0.04)$ & $(0.16)$ \\
\hline Release of carbon in CO & $(0.28)$ & $(1.01)$ \\
\hline Release of carbon in PM & $(0.02)$ & $(0.08)$ \\
\hline Release of carbon in HC, CO, and PM & $(0.34)$ & $(1.26)$ \\
\hline
\end{tabular}

\footnotetext{
${ }^{16}$ Highlighted life cycle stages show cumulative carbon moving through the life cycle. Soybean production shows a net inflow of 169 grams of carbon for 1 bhp-h of engine work. Each subsequent stage consumes carbon, so that, at the point of end-use combustion, the carbon which remains is zero. Inflows of carbon are shown as positive numbers and outflows are shown as negative numbers (in parentheses).
} 
Table 16: LCI Inventory of Raw Material Consumption for Petroleum Diesel (kg/bhp-h)

\begin{tabular}{|l|r|r|r|r|r|l|r|}
\hline Raw Material & $\begin{array}{l}\text { Domestic } \\
\text { Crude Oil } \\
\text { Production }\end{array}$ & $\begin{array}{l}\text { Foreign } \\
\text { Crude Oil } \\
\text { Production }\end{array}$ & $\begin{array}{l}\text { Domestic } \\
\text { Crude Oil } \\
\text { Transport }\end{array}$ & $\begin{array}{l}\text { Foreign } \\
\text { Crude Oil } \\
\text { Transport }\end{array}$ & $\begin{array}{l}\text { Crude Oil } \\
\text { Refining }\end{array}$ & $\begin{array}{l}\text { Diesel } \\
\text { Fuel } \\
\text { Transport }\end{array}$ & \multicolumn{1}{l|}{ Total } \\
\hline Coal & 0.00119 & 0.00104 & 0.000334 & 0.000372 & 0.002544 & 0.000405 & 0.00589 \\
\hline Limestone & 0.00023 & 0.00020 & $6.36 \mathrm{E}-05$ & $7.09 \mathrm{E}-05$ & 0.00048 & $7.73 \mathrm{E}-05$ & 0.00112 \\
\hline Natural Gas & 0.00596 & 0.00311 & $5.19 \mathrm{E}-05$ & 0.000188 & 0.00679 & $9.27 \mathrm{E}-05$ & 0.01620 \\
\hline Oil & 0.09331 & 0.09231 & 0.000196 & 0.001793 & 0.000734 & 0.000598 & 0.18894 \\
\hline Perlite & 0 & 0 & $4.21 \mathrm{E}-08$ & $4.05 \mathrm{E}-07$ & $4.24 \mathrm{E}-05$ & $1.33 \mathrm{E}-07$ & 0.00004 \\
\hline $\begin{array}{l}\text { Phosphate } \\
\text { Rock }\end{array}$ & 0 & 0 & 0 & 0 & 0 & 0 & 0 \\
\hline Potash & 0 & 0 & 0 & 0 & 0 & 0 & 0 \\
\hline $\begin{array}{l}\text { Sodium } \\
\text { Chloride }\end{array}$ & 0 & 0 & 0 & 0 & 0 & 0 & 0 \\
\hline Uranium & $2.86 \mathrm{E}-08$ & $2.50 \mathrm{E}-08$ & $8.00 \mathrm{E}-09$ & $8.91 \mathrm{E}-09$ & $6.03 \mathrm{E}-08$ & $9.71 \mathrm{E}-09$ & $1.41 \mathrm{E}-07$ \\
\hline Water Used & 0.02025 & 0.00549 & $3.58 \mathrm{E}-05$ & 0.000258 & 0.000167 & $9.33 \mathrm{E}-05$ & 0.02629 \\
\hline
\end{tabular}

Table 17: Life Cycle Consumption of Primary Resources for Biodiesel

\begin{tabular}{|l|l|l|l|l|l|l|l|}
\hline Raw Material & $\begin{array}{l}\text { Soybean } \\
\text { Agriculture }\end{array}$ & $\begin{array}{l}\text { Soybean } \\
\text { Transport }\end{array}$ & $\begin{array}{l}\text { Soybean } \\
\text { Crushing }\end{array}$ & $\begin{array}{l}\text { Soybean } \\
\text { Oil } \\
\text { Transport }\end{array}$ & $\begin{array}{l}\text { Soybean } \\
\text { Oil } \\
\text { Conversion }\end{array}$ & $\begin{array}{l}\text { Biodiesel } \\
\text { Transport }\end{array}$ & Total \\
\hline Coal & 0.001328 & 0.000017 & 0.003221 & 0.000035 & 0.002405 & 0.000022 & 0.00703 \\
\hline Limestone & 0.000172 & 0.000003 & 0.000614 & 0.000007 & 0.000340 & 0.000004 & 0.00114 \\
\hline Natural Gas & 0.002599 & 0.000046 & 0.008729 & 0.000097 & 0.019219 & 0.000059 & 0.03075 \\
\hline Oil & 0.006826 & 0.000533 & 0.000519 & 0.001133 & 0.000413 & 0.000689 & 0.01011 \\
\hline Perlite & $1.330 \mathrm{E}-06$ & $1.211 \mathrm{E}-07$ & $0.000 \mathrm{E}+00$ & $2.575 \mathrm{E}-07$ & $0.000 \mathrm{E}+00$ & $1.566 \mathrm{E}-07$ & $1.87 \mathrm{E}-06$ \\
\hline Phosphate Rock & 0.009397 & 0 & 0 & 0 & 0 & 0 & 0.00940 \\
\hline Potash & 0.004417 & 0 & 0 & 0 & 0 & 0 & 0.00442 \\
\hline Sodium Chloride & 0 & 0 & 0 & 0 & 0.00350 & 0 & 0.00350 \\
\hline Uranium & $7.293 \mathrm{E}-08$ & $3.97 \mathrm{E}-10$ & $7.721 \mathrm{E}-08$ & $8.44 \mathrm{E}-10$ & $3.542 \mathrm{E}-08$ & $5.15 \mathrm{E}-10$ & $1.87 \mathrm{E}-07$ \\
\hline Water Used & 86.2493 & $7.41 \mathrm{E}-05$ & 0.0007109 & 0.000158 & 0.113338 & $9.58 \mathrm{E}-05$ & 86.364 \\
\hline
\end{tabular}


Table 18: LCI of Air Emissions for Petroleum Diesel (g/bhp-h) ${ }^{17}$

\begin{tabular}{|l|c|c|c|c|l|l|l|l|}
\hline Air Pollutant & $\begin{array}{l}\text { Domestic } \\
\text { Crude Oil } \\
\text { Production }\end{array}$ & $\begin{array}{l}\text { Foreign } \\
\text { Crude Oil } \\
\text { Production }\end{array}$ & $\begin{array}{l}\text { Domestic } \\
\text { Crude } \\
\text { Transport }\end{array}$ & $\begin{array}{l}\text { Foreign } \\
\text { Crude } \\
\text { Transport }\end{array}$ & $\begin{array}{l}\text { Crude } \\
\text { Oil } \\
\text { Refining }\end{array}$ & $\begin{array}{l}\text { Diesel Fuel } \\
\text { Transport }\end{array}$ & $\begin{array}{l}\text { Diesel } \\
\text { Use }\end{array}$ & Total \\
\hline $\mathrm{NH}_{3}$ & $4.39 \mathrm{E}-09$ & $3.84 \mathrm{E}-09$ & $1.85 \mathrm{E}-09$ & $6.69 \mathrm{E}-09$ & $1.08 \mathrm{E}-08$ & $3.92 \mathrm{E}-09$ & $0.00 \mathrm{E}+00$ & $3.15 \mathrm{E}-08$ \\
\hline Benzene & $2.14 \mathrm{E}-05$ & $2.03 \mathrm{E}-05$ & $4.15 \mathrm{E}-08$ & $4.00 \mathrm{E}-07$ & $1.45 \mathrm{E}-07$ & $1.31 \mathrm{E}-07$ & $0.00 \mathrm{E}+00$ & $4.24 \mathrm{E}-05$ \\
\hline $\mathrm{CO}$ & 0.006091 & 0.011088 & 0.001064 & 0.001546 & 0.043144 & 0.006875 & 1.200000 & 1.269810 \\
\hline Formaldehyde & 0.000277 & 0.000281 & 0.000001 & 0.000005 & 0.000002 & 0.000002 & 0.000000 & 0.000568 \\
\hline NMHC & 0.013648 & 0.015506 & 0.000103 & 0.000306 & 0.000470 & 0.001433 & 0.100000 & 0.131467 \\
\hline $\begin{array}{l}\text { Hydrocarbons } \\
\text { (unspecified) }\end{array}$ & $9.76 \mathrm{E}-05$ & $8.54 \mathrm{E}-05$ & $1.02 \mathrm{E}-02$ & $5.53 \mathrm{E}-02$ & $1.82 \mathrm{E}-01$ & $1.19 \mathrm{E}-03$ & $0.00 \mathrm{E}+00$ & $2.49 \mathrm{E}-01$ \\
\hline $\begin{array}{l}\text { Hydrogen } \\
\text { Chloride }\end{array}$ & 0.000644 & 0.000564 & 0.000180 & 0.000201 & 0.001357 & 0.000219 & 0.000000 & 0.003164 \\
\hline $\begin{array}{l}\text { Hydrogen } \\
\text { Fluoride (HF) }\end{array}$ & $8.05 \mathrm{E}-05$ & $7.05 \mathrm{E}-05$ & $2.25 \mathrm{E}-05$ & $2.51 \mathrm{E}-05$ & $1.70 \mathrm{E}-04$ & $2.73 \mathrm{E}-05$ & $0.00 \mathrm{E}+00$ & $3.96 \mathrm{E}-04$ \\
\hline $\mathrm{CH}_{4}$ & 0.045281 & 0.093621 & 0.002656 & 0.004278 & 0.053414 & 0.003589 & 0.000000 & 0.202839 \\
\hline $\mathrm{NO}_{\mathrm{x}}$ & 0.024000 & 0.015720 & 0.006651 & 0.010242 & 0.129891 & 0.022055 & 4.800000 & 5.008558 \\
\hline $\mathrm{N}_{2} \mathrm{O}$ & 0.004049 & 0.001149 & 0.000034 & 0.000082 & 0.001255 & 0.000216 & 0.000000 & 0.006784 \\
\hline PM10 & 0.000194 & 0.000066 & 0.000159 & 0.000006 & 0.001459 & 0.002210 & 0.080000 & 0.084094 \\
\hline $\begin{array}{l}\text { Particulates } \\
\text { (unspecified) }\end{array}$ & 0.016796 & 0.014704 & 0.004956 & 0.008848 & 0.079114 & 0.005864 & 0.000000 & 0.130281 \\
\hline $\mathrm{SO}_{\mathrm{x}}$ & 0.128553 & 0.083197 & 0.011121 & 0.080880 & 0.440475 & 0.009708 & 0.172402 & 0.926335 \\
\hline
\end{tabular}

\footnotetext{
${ }^{17}$ Note that THC (not listed in the table) is the sum of benzene, formaldehyde, hydrocarbons (unspecified), NMHC (non-methane hydrocarbons), and $\mathrm{CH}_{4}$. Similarly, data we report in other parts of this study for TPM (total particulate matter) represent the sum of PM10 and particulates (unspecified). This latter category represents data in which the type of particulates measured was not specified.

${ }^{18}$ Unspecified hydrocarbons are not the sum of $\mathrm{NMHC}$ and $\mathrm{CH}_{4}$. This is because the unspecified category of emissions is ambiguous. We do not know if original data sources were referring to THC or NMHC. This ambiguity is a common problem in life cycle analysis because of the need to use data collected across a wide range of sources.
} 
Table 19: LCI Air Emissions for Biodiesel (g/bhp-h) ${ }^{19}$

\begin{tabular}{|l|r|r|r|r|r|r|r|r|}
\hline Air Pollutant & $\begin{array}{l}\text { Soybean } \\
\text { Agriculture }\end{array}$ & $\begin{array}{l}\text { Soybean } \\
\text { Transport }\end{array}$ & $\begin{array}{l}\text { Soybean } \\
\text { Crushing }\end{array}$ & $\begin{array}{l}\text { Soybean } \\
\text { Oil } \\
\text { Transport }\end{array}$ & $\begin{array}{l}\text { Soybean Oil } \\
\text { Conversion }\end{array}$ & $\begin{array}{l}\text { Biodiesel } \\
\text { Transport }\end{array}$ & $\begin{array}{l}\text { Biodiesel } \\
\text { Use }\end{array}$ & Total \\
\hline $\mathrm{NH}_{3}$ & 0.0734632 & $2.2735 \mathrm{E}-09$ & $8.02 \mathrm{E}-06$ & $4.83 \mathrm{E}-09$ & $5.4472 \mathrm{E}-09$ & $2.94 \mathrm{E}-09$ & 0 & 0.073471 \\
\hline Benzene & $1.313 \mathrm{E}-06$ & $1.195 \mathrm{E}-07$ & 0 & $2.54 \mathrm{E}-07$ & 0 & $1.54 \mathrm{E}-07$ & 0 & $1.84 \mathrm{E}-06$ \\
\hline $\mathrm{CO}$ & 0.136856 & 0.00602014 & 0.01054 & 0.012727 & 0.0125584 & 0.007782 & 0.64524 & 0.831723 \\
\hline Formaldehyde & $1.78 \mathrm{E}-05$ & $1.60 \mathrm{E}-06$ & $5.20 \mathrm{E}-13$ & $3.40 \mathrm{E}-06$ & $2.38 \mathrm{E}-13$ & $2.07 \mathrm{E}-06$ & 0 & $2.48 \mathrm{E}-05$ \\
\hline $\mathrm{NMHC})$ & 0.0539448 & 0.00129623 & 0.323816 & 0.00019 & 0.00031698 & 0.001676 & 0.06327 & 0.44451 \\
\hline $\begin{array}{l}\text { Hydrocarbons } \\
\text { (unspecified) }\end{array}$ & 0.11591 & 0.00070209 & 0.000263 & 0.00442 & 0.0296103 & 0.000908 & 0 & 0.151813 \\
\hline $\mathrm{HCl}$ & 0.000282 & $8.9382 \mathrm{E}-06$ & 0.001738 & $1.9 \mathrm{E}-05$ & 0.00153278 & $1.16 \mathrm{E}-05$ & 0 & 0.003593 \\
\hline $\mathrm{HF}$ & $1.23 \mathrm{E}-05$ & $1.12 \mathrm{E}-06$ & $2.17 \mathrm{E}-04$ & $2.38 \mathrm{E}-06$ & $9.97 \mathrm{E}-05$ & $1.45 \mathrm{E}-06$ & 0 & 0.000334 \\
\hline $\mathrm{CH}_{4}$ & 0.0283374 & 0.00063603 & 0.064765 & 0.001371 & 0.101683 & 0.000823 & 0 & 0.197616 \\
\hline $\mathrm{NO}_{\mathrm{x}}$ & 0.201205 & 0.0166995 & 0.065193 & 0.062899 & 0.0829794 & 0.021588 & 5.22672 & 5.677283 \\
\hline $\mathrm{N}_{2} \mathrm{O}$ & 0.0013084 & 0.00017635 & 0.000315 & $4.07 \mathrm{E}-05$ & 0.00022874 & 0.000228 & 0 & 0.002297 \\
\hline $\mathrm{PM}_{10}$ & 0.0137127 & 0.00201252 & 0.000592 & 0.001541 & 0.00056848 & 0.002602 & 0.025544 & 0.046572 \\
\hline $\begin{array}{l}\text { Particulates } \\
(\mathrm{unspecified)}\end{array}$ & 0.0154781 & 0.00037925 & 0.045433 & 0.000806 & 0.0357402 & 0.000491 & 0 & 0.098329 \\
\hline $\mathrm{SO}_{\mathrm{x}}$ & 0.0939614 & 0.00261499 & 0.248258 & 0.005551 & 0.498182 & 0.003382 & 0 & 0.851949 \\
\hline
\end{tabular}

\footnotetext{
${ }^{19}$ Note that THC (not listed in the table) is the sum of benzene, formaldehyde, hydrocarbons (unspecified), NMHC (non-methane hydrocarbons), and $\mathrm{CH}_{4}$. Similarly, data we report in other parts of this study for TPM (total particulate matter) represent the sum of PM10 and particulates (unspecified). This latter category represents data in which the type of particulates measured was not specified.

${ }^{20}$ Unspecified hydrocarbons are not the sum of $\mathrm{NMHC}$ and $\mathrm{CH}_{4}$. This is because the unspecified category of emissions is ambiguous. We do not know if original data sources were referring to THC or NMHC. This ambiguity is a common problem in life cycle analysis because of the need to use data collected across a wide range of sources.
} 
Table 20: Air Emissions for Petroleum Diesel, B20, and B100 (g/bhp-h) ${ }^{21}$

\begin{tabular}{|l|r|r|r|}
\hline Pollutant & $\begin{array}{l}\text { Petroleum } \\
\text { Diesel }\end{array}$ & B20 & B100 \\
\hline $\mathrm{CH}_{4}$ & 0.202839 & 0.201795 & 0.197616 \\
\hline $\mathrm{NO}_{\mathrm{x}}$ & 0.006784 & 0.005887 & 0.002297 \\
\hline $\mathrm{CO}$ & 1.26981 & 1.18219 & 0.831723 \\
\hline $\mathrm{NMHC}$ & 0.131467 & 0.194075 & 0.44451 \\
\hline Hydrocarbons (unspecified) ${ }^{22}$ & 0.249053 & 0.229605 & 0.151814 \\
\hline Benzene & $4.24 \mathrm{E}-05$ & $3.43 \mathrm{E}-05$ & $1.84 \mathrm{E}-06$ \\
\hline Formaldehyde & 0.000568 & 0.000459 & $2.48 \mathrm{E}-05$ \\
\hline $\mathrm{PM}_{0} 0$ & 0.084094 & 0.076589 & 0.046572 \\
\hline Particulates (Unspecified) & 0.130281 & 0.123891 & 0.098329 \\
\hline $\mathrm{SO}_{\mathrm{x}}$ & 0.926335 & 0.911458 & 0.851949 \\
\hline $\mathrm{NO}_{\mathrm{x}}$ & 5.00856 & 5.1423 & 5.67728 \\
\hline $\mathrm{HCl}$ & 0.003164 & 0.00325 & 0.003593 \\
\hline $\mathrm{HF}$ & 0.000396 & 0.000383 & 0.000334 \\
\hline $\mathrm{NH}_{3}$ & $3.15 \mathrm{E}-08$ & 0.014694 & 0.073471 \\
\hline
\end{tabular}

${ }^{21}$ Note that THC (not listed in the table) is the sum of benzene, formaldehyde, hydrocarbons (unspecified), NMHC (Non Methane Hydrocarbons), and $\mathrm{CH}_{4}$. Similarly, data we report in other parts of this study for TPM (total particulate matter) represent the sum of PM10 and Particulates (unspecified). This latter category represents data in which the type of particulates measured was not specified.

${ }^{22}$ Unspecified hydrocarbons are not the sum of $\mathrm{NMHC}$ and $\mathrm{CH}_{4}$. This is because the unspecified category of emissions is ambiguous. We do not know if original data sources were referring to total hydrocarbons or NMHC. This ambiguity is a common problem in life cycle analysis because of the need to use data collected across a wide range of sources. 
Table 21: Relative Change in Life Cycle Air Emissions for Fuels Containing $20 \%$ and $100 \%$ Biodiesel

\begin{tabular}{|l|r|r|}
\hline Pollutant & B20 & B100 \\
\hline $\mathrm{CO}$ & $-6.90 \%$ & $-34.50 \%$ \\
\hline $\mathrm{PM}$ & $-6.48 \%$ & $-32.41 \%$ \\
\hline $\mathrm{HF}$ & $-3.10 \%$ & $-15.51 \%$ \\
\hline $\mathrm{SOx}$ & $-1.61 \%$ & $-8.03 \%$ \\
\hline $\mathrm{CH}_{4}$ & $-0.51 \%$ & $-2.57 \%$ \\
\hline $\mathrm{NOx}$ & $2.67 \%$ & $13.35 \%$ \\
\hline $\mathrm{HCl}$ & $2.71 \%$ & $13.54 \%$ \\
\hline $\mathrm{HC}$ & $7.19 \%$ & $35.96 \%$ \\
\hline
\end{tabular}

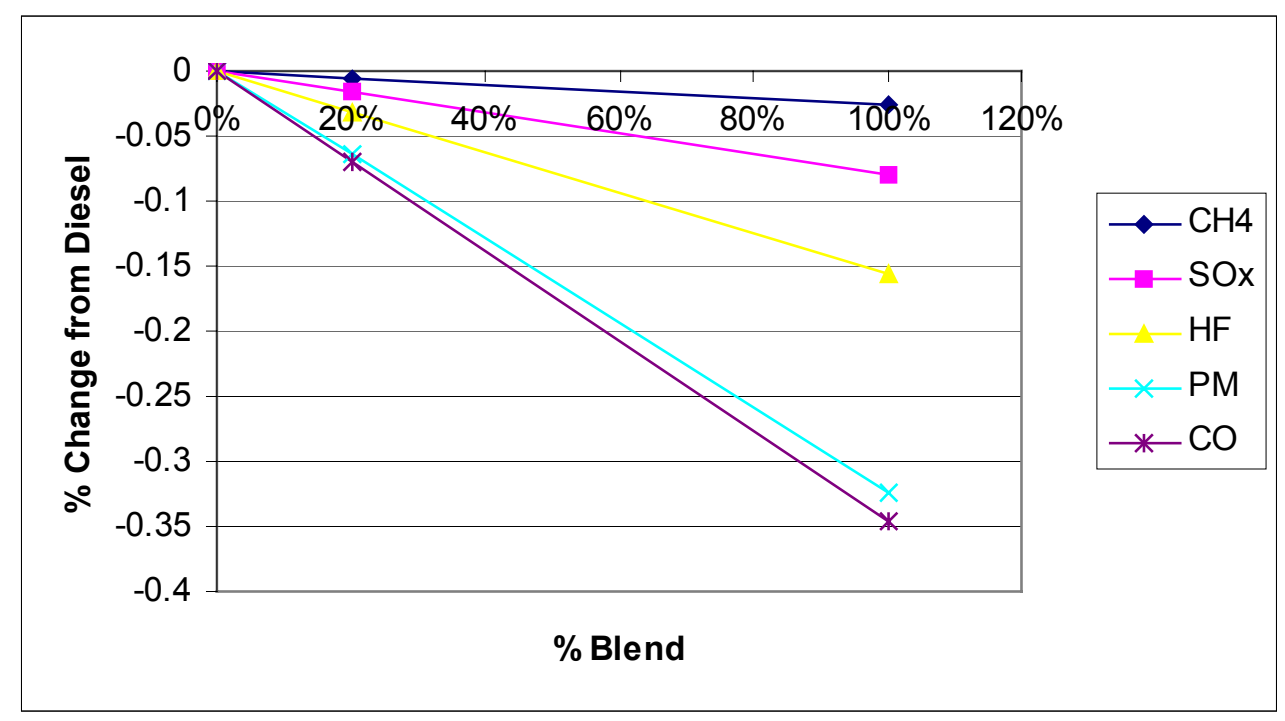

Figure 23: Effect of Biodiesel Blend on Life Cycle Air Emissions of $\mathrm{CH}_{4}, \mathrm{SO}_{\mathrm{x}}, \mathrm{HF}, \mathrm{PM10}$, and CO 


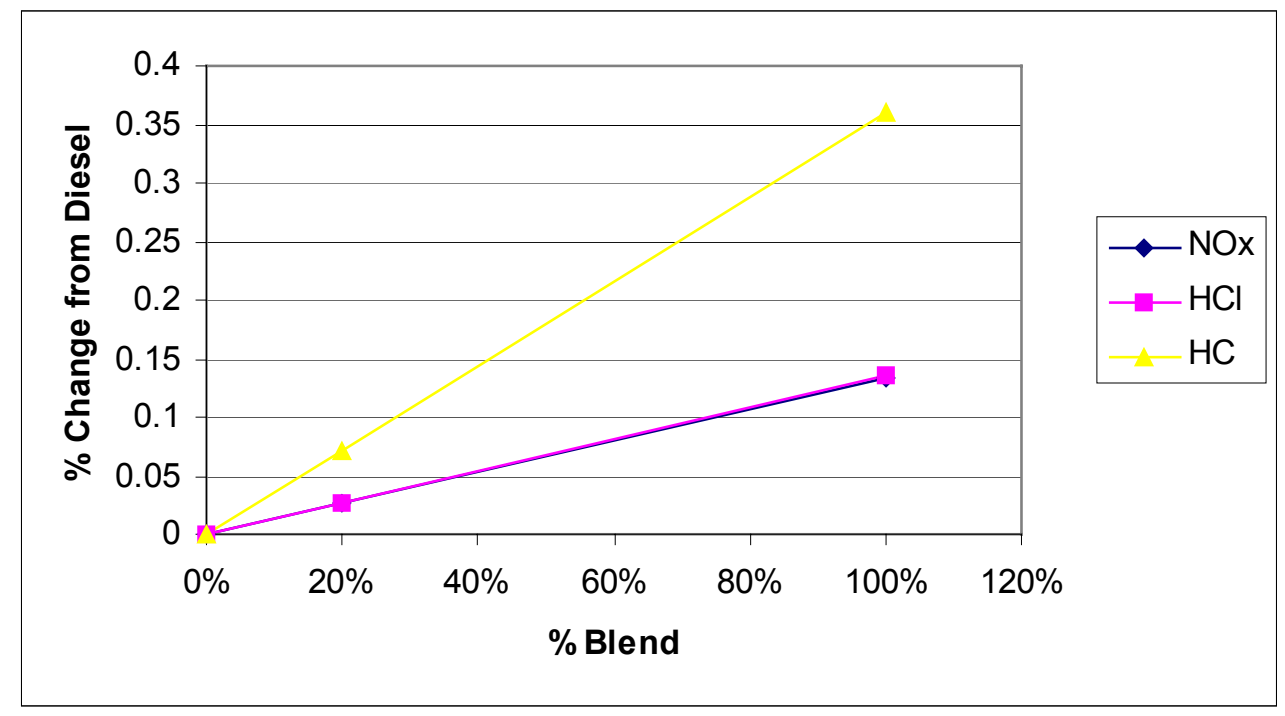

Figure 24: Effect of Biodiesel Blend Level on Air Emissions of $\mathrm{NO}_{\mathrm{x}}, \mathrm{NMHC}$ and $\mathrm{HCl}$ 


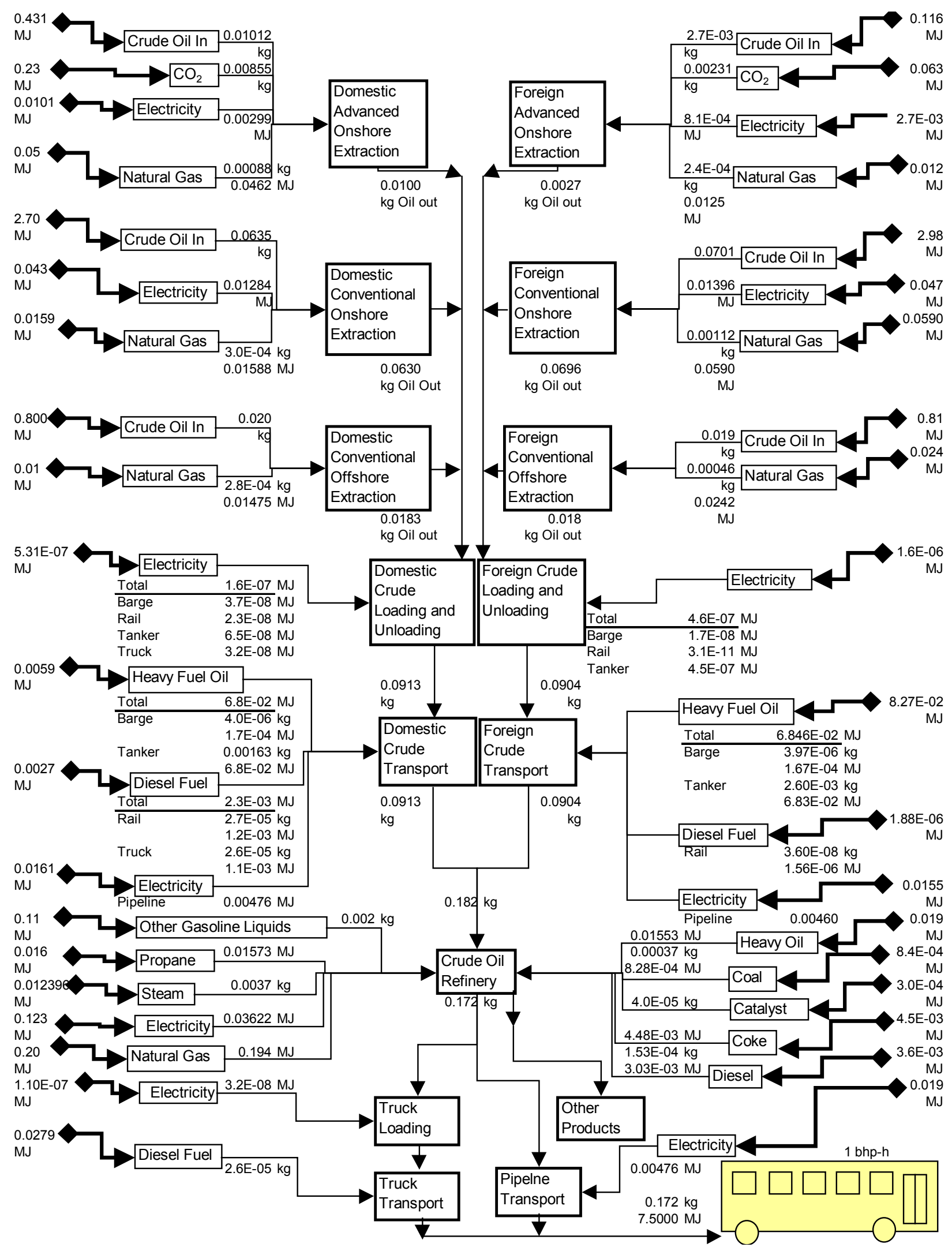

Figure 25: Primary Energy Balance for the Petroleum Diesel Fuel Life Cycle (with Mass Allocation) 


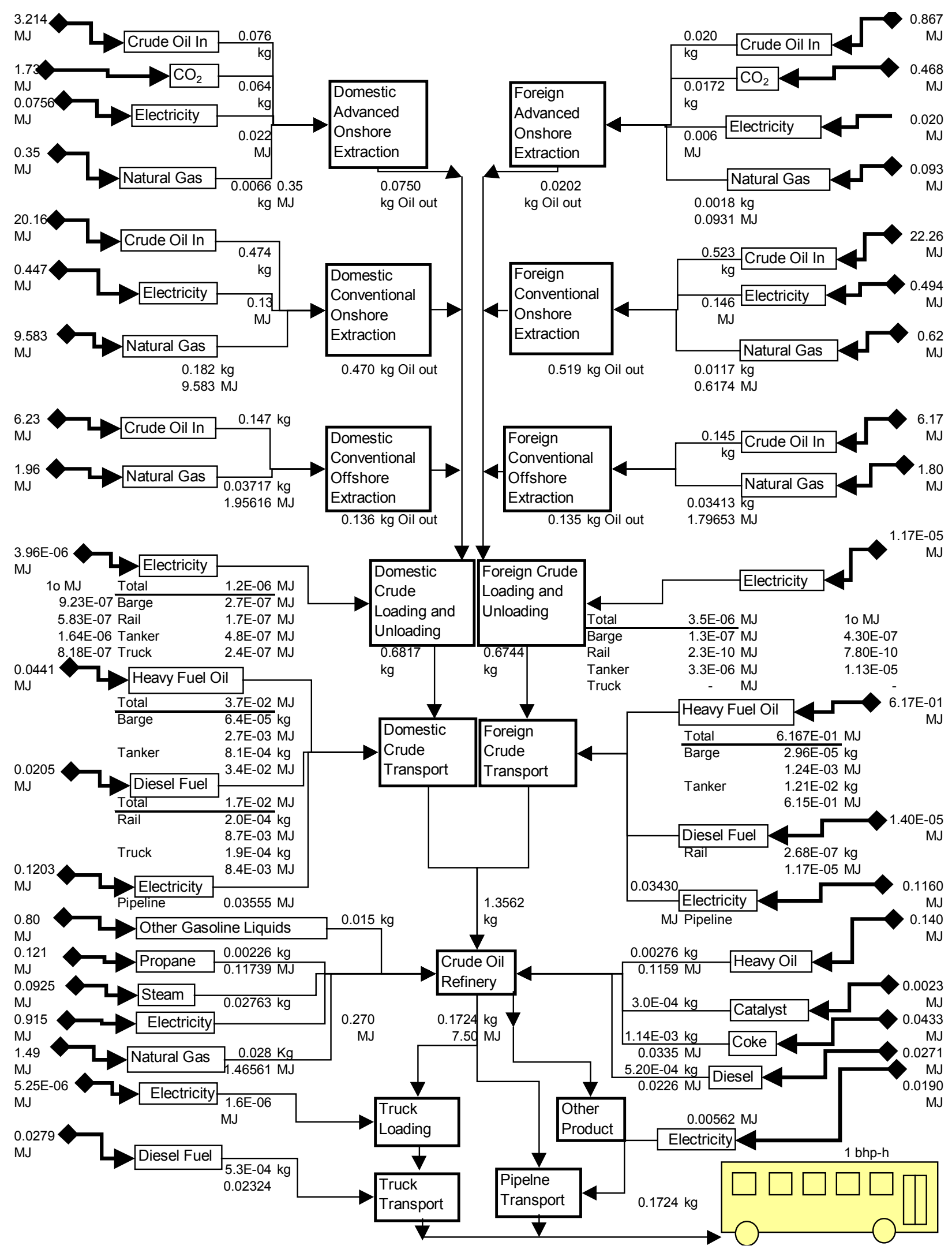

Figure 26: Primary Energy Balance for Petroleum Diesel Fuel Life Cycle (No Mass Allocation) 


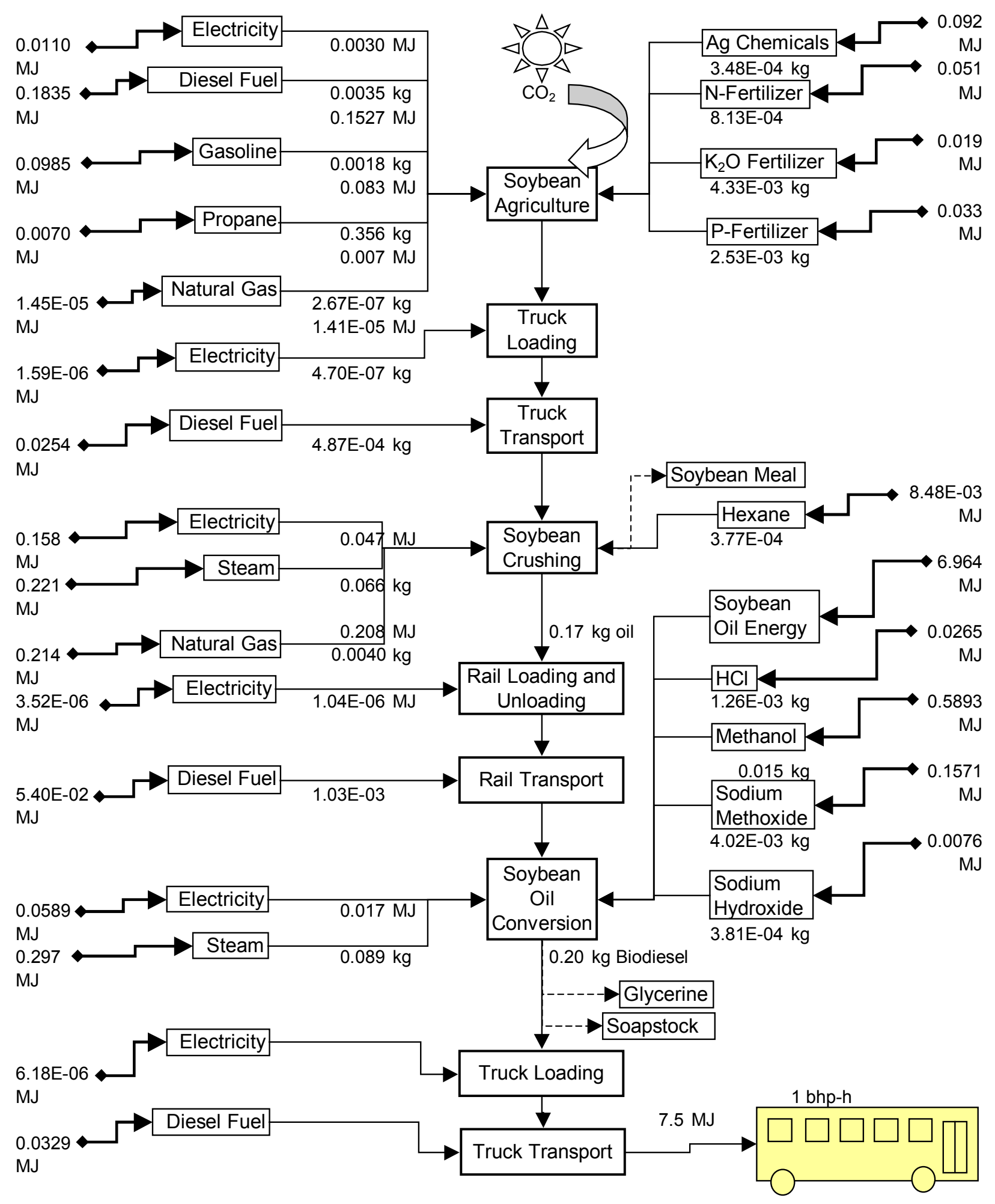

Figure 27: Primary Energy Balance for Biodiesel Fuel Life Cycle (with Mass Allocation) 


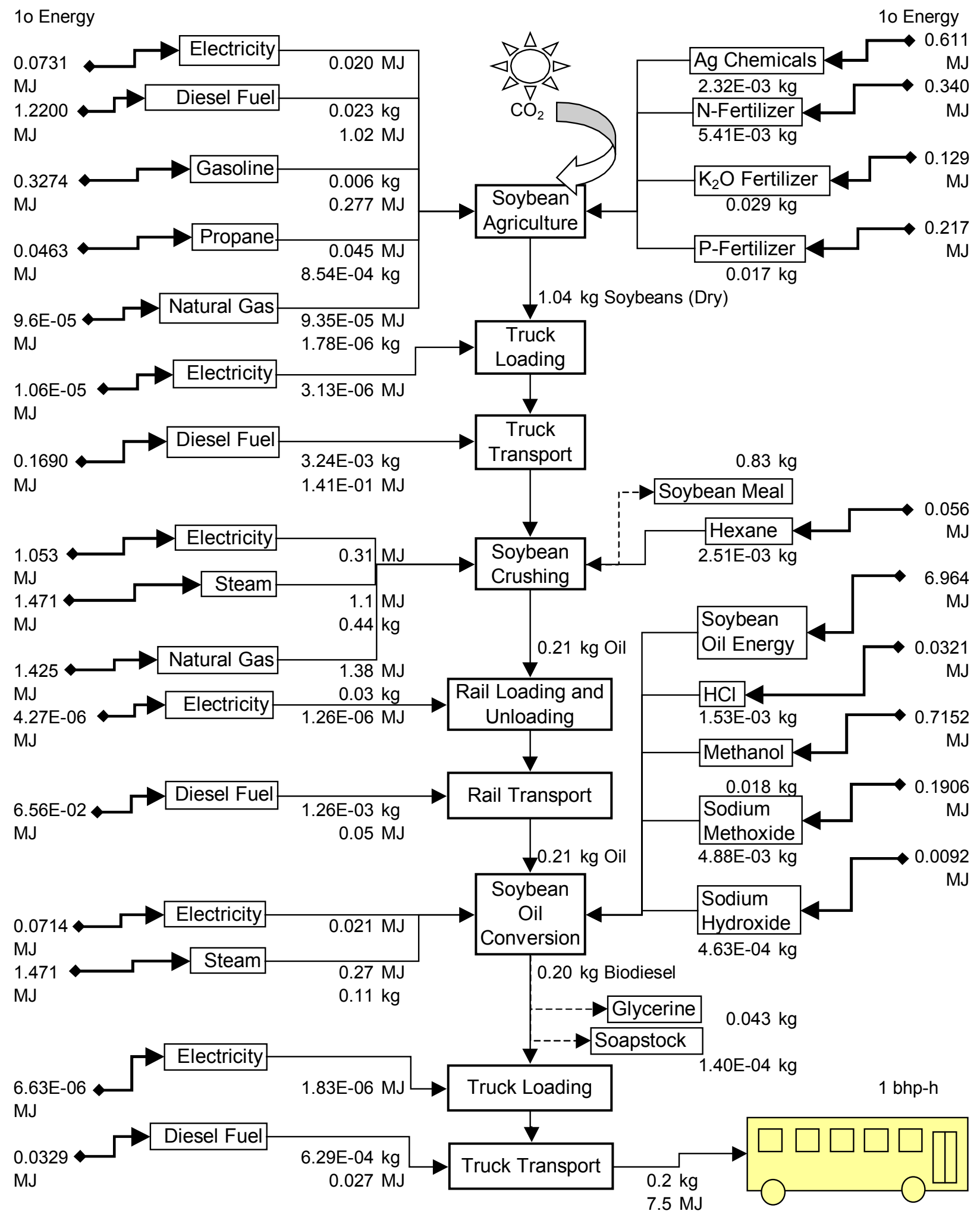

Figure 28: Primary Energy Balance for Biodiesel Fuel Life Cycle (No Mass Allocation) 


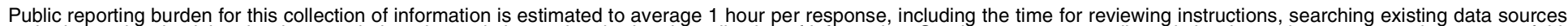

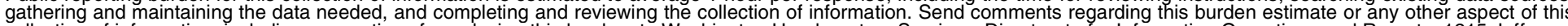

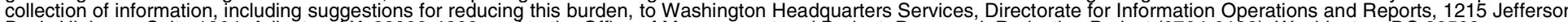

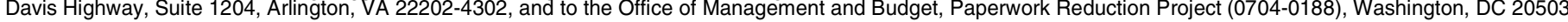

\begin{tabular}{|l|l|l}
\hline 1. AGENCY USE ONLY (Leave blank) & $\begin{array}{l}\text { 2. REPORT DATE } \\
\text { May } 1998\end{array}$ & $\begin{array}{c}\text { 3. REPORT TYPE AND DATES COVERED } \\
\text { Technical Report }\end{array}$
\end{tabular}

\section{TITLE AND SUBTITLE: An Overview of Biodiesel and Petroleum Diesel Life Cycles}

5. FUNDING NUMBERS

BF886002

6. AUTHOR(S): John Sheehan, James Duffield, Housein Shapouri, Michael Graboski, Vince Camobreco

7. PERFORMING ORGANIZATION NAME(S) AND ADDRESS(ES)

National Renewable Energy Laboratory

8. PERFORMING ORGANIZATION REPORT NUMBER

1617 Cole Boulevard

Golden, CO 80401-3393

U.S. Department of Energy

U.S. Department of Agriculture

Ecobalance, Inc.

Colorado School of Mines, Colorado Institute for Fuels and Engine Research

9. SPONSORING/MONITORING AGENCY NAME(S) AND ADDRESS(ES)

National Renewable Energy Laboratory

1617 Cole Boulevard

Golden, CO 80401-3393

\section{SUPPLEMENTARY NOTES}

12a. DISTRIBUTION/AVAILABILITY STATEMENT

National Technical Information Service

U.S. Department of Commerce

5285 Port Royal Road

Springfield, VA 22161

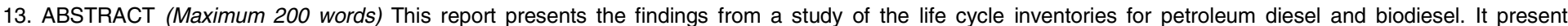
information on raw materials extracted from the environment, energy resources consumed, and air, water, and solid waste emissions generated.

14. SUBJECT TERMS: biodiesel, life cycle inventory, petroleum diesel

15. NUMBER OF PAGES: 60

16. PRICE CODE

17. SECURITY CLASSIFICATION

OF REPORT
18. SECURITY CLASSIFICATION OF THIS PAGE
19. SECURITY CLASSIFICATION OF ABSTRACT 12b. DISTRIBUTION CODE

UC-1503
SPONSORING/MONITORING

AGENCY REPORT NUMBER

NREL/TP-580-24772

NSN 7540-01-280-5500Ｓ Standard Form 298 (Rev. 2-89)

Prescribed by ANSI Std. Z39-18298-102 


\section{For more information contact:}

Michael Voorhies

Program Manager

Office of Fuels Development

U.S. Department of Energy

1000 Independence Avenue, SW

Forrestal Building

Washington, D.C. 20585-0121

James Duffield

Office of Energy

U.S.Department of Agriculture

1800 M. Street, NW

Washington, D.C. 20036

Prepared for the

U.S. Department of Energy (DOE)

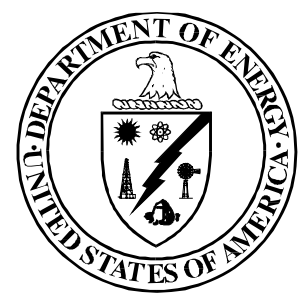

and the U.S. Department of Agriculture (USDA)

by the National Renewable Energy Laboratory a U.S. Department of Energy national laboratory
K. Shaine Tyson

Biodiesel Project Manager

National Renewable Energy Laboratory

1617 Cole Blvd

Golden, CO 80401

\section{John Sheehan}

Biotechnology Center for Fuels and Chemicals

National Renewable Energy Laboratory

1617 Cole Blvd

Golden, CO 80401

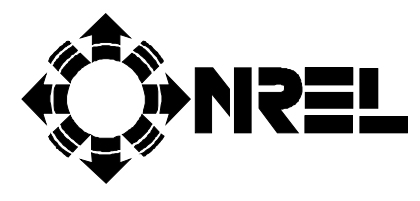

